Portland State University

PDXScholar

1989

\title{
An Analysis of the Effect of State Regulation of Commercial Income Tax Preparers on the Quality of Income Tax Returns
}

Jeanie Grace Sumner

Portland State University

Follow this and additional works at: https://pdxscholar.library.pdx.edu/open_access_etds

Part of the Strategic Management Policy Commons, and the Taxation Commons Let us know how access to this document benefits you.

\section{Recommended Citation}

Sumner, Jeanie Grace, "An Analysis of the Effect of State Regulation of Commercial Income Tax Preparers on the Quality of Income Tax Returns" (1989). Dissertations and Theses. Paper 1172.

https://doi.org/10.15760/etd.1171

This Dissertation is brought to you for free and open access. It has been accepted for inclusion in Dissertations and Theses by an authorized administrator of PDXScholar. Please contact us if we can make this document more accessible: pdxscholar@pdx.edu. 


\title{
AN ANALYSIS OF THE EFFECT OF STATE REGULATION OF COMMERCIAL INCOME TAX PREPARERS ON THE QUAIITY OF INCOME TAX RETURNS
}

\author{
by \\ JEANIE GRACE SUMNER
}

A dissertation submitted in partial fulfillment of the requirements for the degree of
DOCTOR OF PHILOSOPHY in SYSTEMS SCIENCE

Portland State University

(C) 1989 


\section{TO THE OFFICE OF GRADUATE STUDIES:}

The members of the Committee approve the dissertation of Jeanie Grace Sumner presented June 26, 1989.

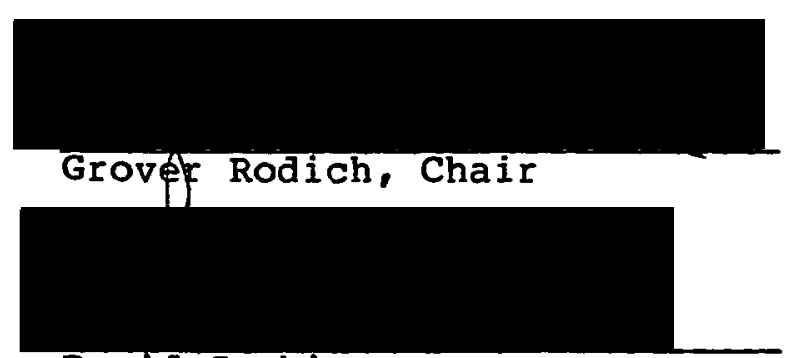

David Gerbing

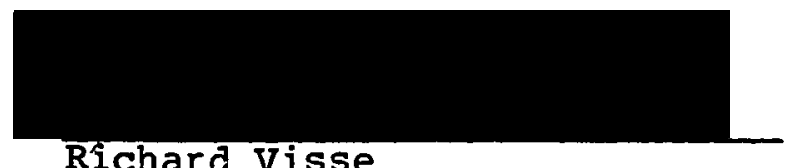

Richard Visse

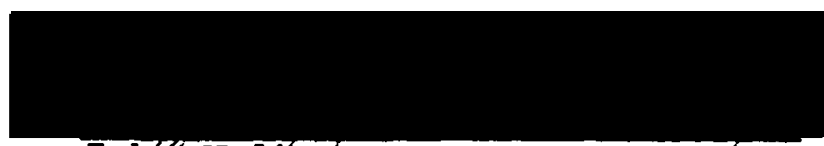

Jobn Walket

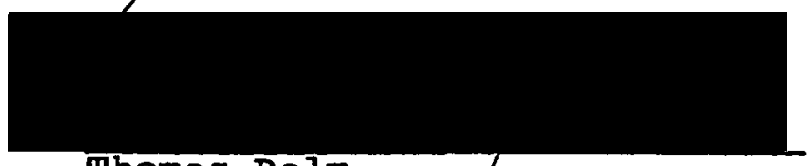

Thomas Palm

APPROVED:

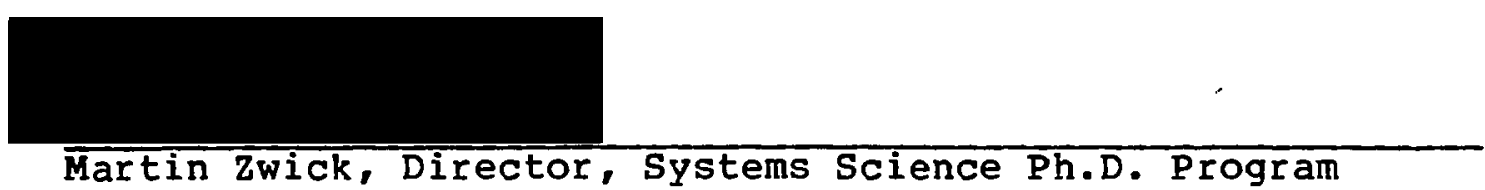

Martin Zwick, Director, Systems Science Ph.D. Program

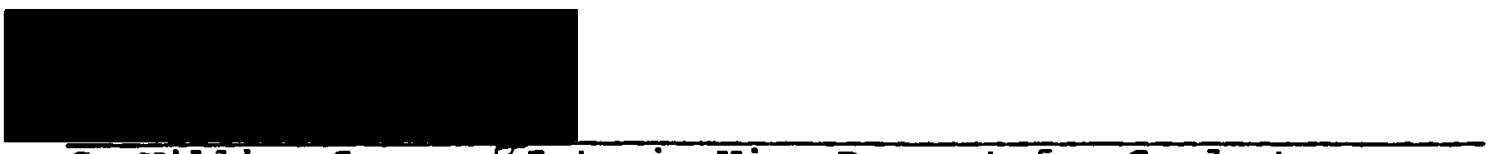

C. William Savery, Interim Vice Provost for Graduate Studies and Research 
AN ABSTRACT OF THE DISSERTATION OF Jeanie Grace Sumner for the Doctor of Philosophy in Systems Science presented June $26,1989$.

Title: An Analysis of the Effect of State Regulation of Commercial Income Tax Preparers on the Quality of Income Tax Returns

APPROVED BY THE MEMBERS OF THE DISSERTATION COMMITTEE:

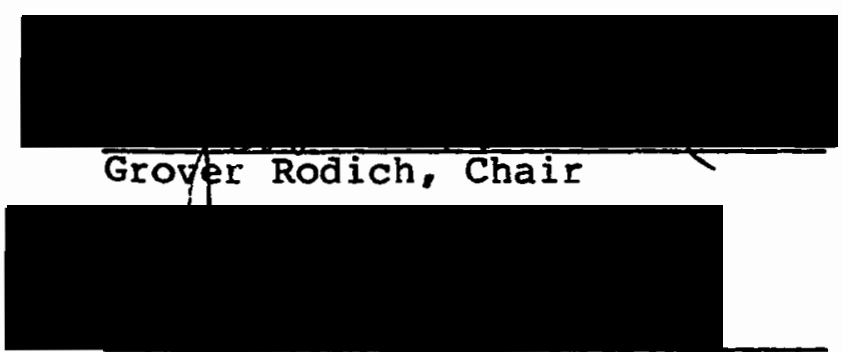
David Gerbing

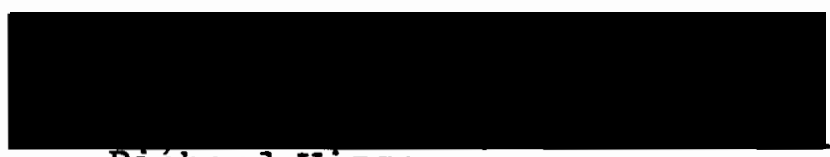

Richard Visse

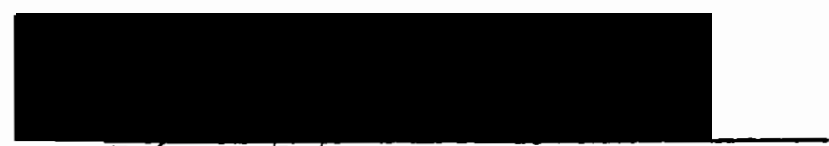

Johnn Walker

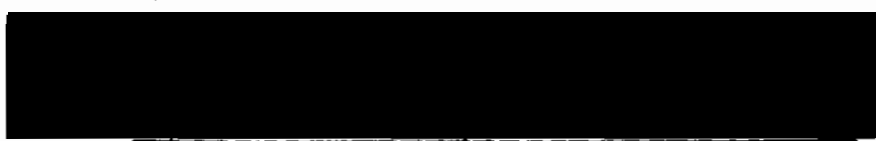

Thomas PaIm 
Occupational regulation of many professions has grown in magnitude and complexity in the past fifty years. Statutes relating to occupational regulation are often implemented by state legislatures without sufficient quantitative analysis.

Prior studies have analyzed the need for regulation to protect consumers. Some research has been published which addresses the differences in the quality of services offered by regulated and unregulated professions. Due to lack of data, the effect of state regulation on commercial income tax preparers has not been quantified.

Recently data from the 1979 cycle of the Taxpayer Compliance Measurement Program (TCMP) have been made available by the Internal Revenue Service (IRS). TCMP is an IRS audit program that is used to estimate how well taxpayers are complying with the income tax laws. Those data provide the opportunity for analysis relating to the question of the quality of services offered by commercial income tax preparers in regulated and unregulated states. The analysis evaluated differences in error rates or amounts between returns prepared in a highly regulated state--oregon, a state with minimum regulation--California, and the remaining forty-eight unregulated states. Items were chosen from the tax returns to evaluate the integrity and competency of the commercial tax preparer, the effect of continuing education requirements and the accumulated 
effect of the totals of income, adjustments and deductions on the quality of the returns.

Descriptive statistics, cluster analysis, and nonparametric methods were used in the research. Descriptive measures indicated that Oregon's error rates were among the lowest while California's errors were among the highest in the country. Cluster analysis grouped oregon with states in the midwest while California grouped with other states in the sunbelt.

The nonparametric tests indicated that Oregon's error rates and amounts were statistically smaller than the unregulated states. When Oregon was compared to the clustered states or to the states in the Northwest, the differences were not significant. When the tests were completed for the items chosen from California's returns, it was evident that the error rates were substantially higher on the samples from California than the unregulated states. When California's errors were considered relative to the states from the sunbelt, the results were similar although not as substantial. The final comparison was made relative to levels of regulation. The errors on the returns from California were significantly larger than those from Oregon in all of the areas tested. The data available from the 1979 TCMP audits are currently very limited. The IRS may be releasing the files 
in the near future for general academic research. These files will provide excellent opportunities for expanded research on the topic of return preparation relative to the type of preparer and many other areas of tax compliance and administration. 
TABLE OF CONTENTS

PAGE

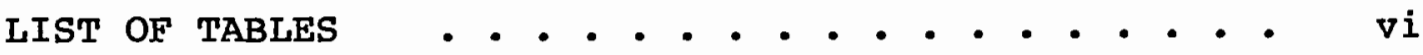

LIST OF FIGURES . . . . . . . . . . . . . . . . ix

CHAPTER

I INTRODUCTION . . . . . . . . . . . . . . I

Background . . . . . . . . . . . . 1

Statement of the Problem . . . . . . . 3

The Research Hypothesis . . . . . . . 3

Significance of the Research . . . . . . 4

Scope of the Data Available . . . . . 5

Overview of the Dissertation . . . . . 5

II REVIEW OF LITERATURE 7

Occupational Regulation . . . . . . . 7

Views of the Major Authors

Self-Regulation

Constitutional Validity

Interstate Mobility

Levels of Regulation

The Medical Profession

Restricted Entry and Quality of Service

Conclusions

The Tax Preparation Industry . . . . . 21

History of the Tax Preparer

State Regulation of Commercial Income

Tax Preparers

Research on Quality of Tax Return

Preparation 
Federal Regulation

PAGE

The 1976 Tax Legislation

Recent Research

Current Opinions

The Null Hypotheses and Their Alternatives

Integrity of Commercial Preparers Competency of Commercial Preparers on New Tax Items

Competency of Commercial Preparers on $T$ roublesome Items

Cumulative Effect of Total Errors on Tax Returns

Differences in Levels of Regulation of Commercial Preparers

Methodology Iimitation . . . . . . . .

The Data Source . . . . . . . . . . 44

Description of the Data... . . . . . 45

Preparation of the Data . . . . . . . 4 46

The Model Tax Return . . . . . . . . 47

Statistical Methods of Analysis . . . . . 49

Descriptive statistics

Cluster Analysis

Nonparametric statistics

Descriptive Results . . . . . . . .

Model Tax Returns

Comparison by Preparer Type

Graphic Representations of the Data

Cluster Analysis

Nonparametric Results and Interpretations .

Measurement Methodology

Hypothesis I 
PAGE

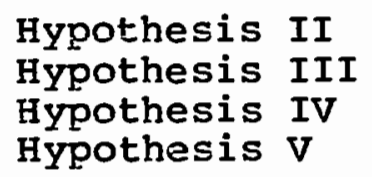

VI INTERPRETATIONS AND CONCLUSIONS . . . . . . 91

Summary • • • • . . . . . . . . 91

Descriptive Measures

Analysis Using Nonparametric

Statistics

Conclusions . . . . . . . . . 96

Limitations . . . . . . . . . . 99

Suggestions for Future Research . . . 100

REFERENCES

.. . . . . . . . . . . . . 103

APPENDICES

A Bar Charts . . . . . . . . . . . 112

B TCMP Data and Model Tax Returns • • . • 115

C Density Stripe Graphs and Cluster Analysis • 140

D TCMP Handbook . . . . . . . . . . 146 
LIST OF TABLES

TABLE

PAGE

I Commercial Tax Preparer Types . . . . . . . 48

II Compliance by Type of Income, Deduction and Tax: Summary Ratio of Total Reported Amounts to Total Corrected Amount . . . . . . . . . . 60

III Nonregulated States: Comparison with Oregon 70

IV Clustered States: Comparison With Oregon . • 71

v Northwestern States: Comparison With Oregon 72

VI Selected Nonregulated States: Comparison With California... . . . . . . 72

VII Clustered states: Comparison With California . . . . . . . . . 73

VIII Southwestern States: Comparison With California . . . . . . . . . . 74

IX Nonregulated states: Comparison with Oregon 76

X Clustered States: Comparison With Oregon . - 77

XI Northwestern States: Comparison with Oregon 77

XII Nonregulated states: Comparison With Oregon .............. . 79

XIII Clustered States: Comparison with Oregon - 80

XIV Northwestern States: Comparison With Oregon 81

XV Selected Nonregulated States: Comparison With California... . . . . . . 82

XVI Clustered states: Comparison with California . . . . . . . . . 82 
XVII Southwestern States: Comparison with California ............. 83

XVIII Nonregulated States: Comparison With Oregon 85

XIX Clustered States: Comparison with Oregon . . 86

XX Northwestern States: Comparison with Oregon 86

XXI Selected Nonregulated States: Comparison with California.......... 87

XXII Southwestern States: Comparison with California .. . . . . . . . . 88

XXIII Comparison of California With Oregon . . . 89

XXIV Hypothesis I Example of TCMP Data Prepared For Statistical Tests . . . . . . 116

XXV Hypothesis II Example of TCMP Data Prepared For Statistical Tests . . . . . . 117

XXVI Hypothesis III Example of TCMP Data Prepared For Statistical Tests........ 118

XXVII Hypothesis IV Example of TCMP Data Prepared For Statistical Tests . . . . . . . 119

XXVIII Model of Tax Returns prepared by All Types of Taxpayers in Fifty States . . . . 120

XXIX Model of Tax Returns Prepared by Nine Types of Tax Preparers in Fifty States . . . 121

XXX Model of Tax Returns Prepared by Taxpayers and Unpaid Preparers in Fifty States • 122

XXXI Model of Tax Returns prepared by Commercial Preparers in Fifty states . . . . . 123

XXXII Model of Tax Returns Prepared by Professional Preparers in Fifty States . . . . . 124

XXXIII Model of Tax Returns Prepared by Commercial Preparers in Arizona . . . . . . 125

XXXIV Model of Tax Returns Prepared by Commercial Preparers in California . . . . . . 126 
XXXV Model of Tax Returns prepared by Commercial Preparers in Florida . . . . . . 127

XXXVI Model of Tax Returns Prepared by Commercial Preparers in Hawaii . . . . . . . 128

XXXVII Model of Tax Returns Prepared by Commercial Preparers in Kansas . . . . . . . 129

XXXVIII Model of Tax Returns Prepared by Commercial Preparers in Kentucky . . . . . . . 130

XXXIX Model of Tax Returns Prepared by Commercial Preparers in Massachusetts . . . . 131

XI Model of Tax Returns Prepared by Commercial Preparers in Nebraska . . . . . . 132

XLI Model of Tax Returns Prepared by Commercial Preparars in New Mexico ....... 133

XLII Model of Tax Returns Prepared by Commercial Preparers in New York . . . . . . 134

XIIII Model of Tax Returns Prepared by Commercial Preparers in North Dakota..... . 135

XIIV Model of Tax Returns Prepared by Commercial Preparers in Oregon . . . . . . . 136

XIV Model of Tax Returns Prepared by Commercial Preparers in Virginia... . . . . 137

XLVI Model of Tax Returns Prepared by Commercial Preparers in Washington .. . . . . 138

XLVII Model of Tax Returns Prepared by Commercial Preparers in Wisconsin . . . . . . 139 
IIST OF FIGURES

FIGURE

PAGE

1 Diagram of information provided in a box plot . . . . . . . . . . . . .

2 Taxpayer Compliance Measurement Program (TCMP) examination sample data total dollar errors by stare... . . . .

3 Taxpayer Compliance Measurement Program (TCMP) examination sample data percentage of income . . . . . . . 114

4 Comparison of sample from Oregon and selected northeastern states... . 141

5 Comparison of sample data from California and states with highest average errors . . . . . . . . . . . .

6 Hierarchical structure illustrating the partitioning of the clusters . . . . 143

7 Summary statistics for $\mathrm{k}$-means cluster anaiysis . . . . . . . . . . . .

8 Box and whisker plots of cluster variables including a key to the numbers of each cluster 
CHAPTER I

\section{INTRODUCTION}

Occupational regulation of many professions by state governments has grown in magnitude and complexity in the past fifty years. While the supreme court has called the right to make a living a man's most precious heritage (Barsky v. Board of Regents, 1954 : 659), states have limited the ability of workers to enter a myriad of professions. Decisions relating to occupational regulation are made by state legislatures. Such statutes are based on testimony by individuals and groups directly affected. These statutes are often enacted without analysis and based on insufficient and inaccurate data.

\section{BACKGROUND}

Numerous authors have indicated that occupational regulation should be limited to professions where the potential of irreparable harm to consumers clearly outweighs the associated economic costs of regulation (Young, 1986; Fellmeth, 1985; Kleiner, Gay and Greene, 1982; Elliott and Smith, 1978; and Stolar, 1976). The differences in the quality of services provided by regulated 
and unregulated professions has been analyzed in some professions; however, due to lack of data, the effect of state regulation of commercial income tax preparers has not been quantified.

Oregon and California regulate commercial income tax preparers while the remaining states do not regulate this industry. Oregon licenses commercial income tax preparers, and requires passing scores on two examinations and continuing professional education for relicensing. California registers commercial tax preparers, requires completion of continuing professional education courses and posting of a performance bond for reregistration.

The issue of regulation of commercial income tax preparers stems from interest in the topic at the federal level during the mid 1970s. The General Accounting office (GAO) completed a study entitled No Apparent Need to Regulate Commercial Income Tax Preparers for Congress in 1975. While the title indicates a clear-cut conclusion, the study itself left the issue of state regulation unresolved.

The concluding comments from the GAO study are:

The question remains whether regulation of the entire industry, including the professionals and others, is desirable in order to generally improve performance.

We do not know. There is no data with which to estimate its potential benefits. Perhaps the experience of California and Oregon, states which recently adopted regulation, will provide some basis for future evaluation (GAO, 1975: 20). 
STATEMENT OF THE PROBLEM

The problem of this study can be stated as: Are there relationships between the components of state regulation of commercial income tax preparers and the quality of the service they provide to consumers as measured by the magnitude of errors and changes resulting from examination of a sample of completed tax returns?

\section{THE RESEARCH HYPOTHESIS}

A survey of the literature indicates that the number of regulated occupations has grown rapidly in the past fifty years. The studies cited indicate that regulation should be limited to fields where the consumer lacks enough information to choose the proper product or service. As the tax laws and tax forms have become more complex, many families have turned to commercial income tax preparers to help with the task of complying with the income tax regulations.

Very little research has been completed which evaluates the quality of services provided by regulated occupations. With the data available from the Taxpayer Compliance Measurement Program (TCMP) examinations, this research can address the issue of quality of services in the commercial tax preparation industry. 
The research hypothesis is that state regulation of commercial income tax preparers should improve the quality of income tax return preparation.

\section{SIGNIFICANCE OF THE RESEARCH}

Commercial income tax preparers represent a specific segment of the tax preparation industry. Responses by taxpayers during the TCMP examination indicated that 38 percent of the returns were prepared by commercial preparers. Commercial preparers are independent individuals, employees of local and national tax services and public accountants. Certified Public Accountants and lawyers will be excluded from current consideration because they are regulated by all states.

A clear and quantifiable basis for legislative decision making in expansion or reduction of state regulation of commercial income tax preparers does not exist. I way to establish such a basis for analysis would be to study differences among the returns prepared in Oregon, California and the remaining states. Such analysis should be based on knowledge of the underlying applicable income tax law. The results from such analysis would significantly enhance the knowledge relative to the economic theory of occupational regulation and provide information for legislators making occupational regulatory decisions regarding tax preparation and other fields. 
SCOPE OF THE DATA AVAILABLE

Historically, research based on information obtained from examination of income tax returns has been limited by lack of data. Recently the Internal Revenue Service has made additional data sources available for academic research. Among these is the Taxpayer Compliance Measurement Program (TCMP) information. Data collected by the Internal Revenue Service in their 1979 cycle of the TCMP is categorized by thirteen types of tax return preparers and can be sorted by state. The data base is composed of information gathered from 55,000 randomly selected taxpayers. Answers to the Internal Revenue Service examiners' questions have been aggregated and arranged so that differences between amounts as reported and as corrected on approximately ninety items of income and deductions can be evaluated. These ninety items represent questions of tax treatment varying from the changes caused by arithmetic errors to complex issues of income tax law. OVERVIEW OF THE DISSERTATION

The remainder of this dissertation is organized as follows. The second chapter reviews the relevant literature. A summary of the essays by Milton Friedman and walter Gellhorn is used as a framework for the more current research on occupational regulation. The history of the tax preparation industry and the development of the 
national tax services in the 1950 s are reviewed. Regulation of commercial tax preparers in Oregon and California is considered. Federal research and the resulting tax legislation, including preparer penalties, are summarized. More recent research and current conflicting upinions on the need for regulation of commercial tax preparers are presented.

The third chapter describes the design of the study in more detail. The null hypotheses and their alternatives are presented. The fourth chapter contains the data description and analysis. The Taxpayer Compliance Measurement Program is described. The statistical methods are presented and compared.

The results of the statistical analysis are presented and interpreted in Chapter V. The sixth and last chapter discusses the results, summarizes the conclusions, considers the limitations and states the need for future research. 
CHAPTER II

REVIEW OF LITERATURE

Contemporary discussions of occupational regulation can be traced to the essays of two authors: Milton Friedman and Walter Gellhorn. A summary of their discussions is used as an outline for the survey of the literature on occupational licensure, followed by more specific aiscussions of the history and regulation of commercial income tax preparers.

OCCUPATIONAL REGULATION

Views of the Major Authors

Milton Friedman offers a conservative view of occupational licensure, making a case for dispensing with all state regulation of professional or occupational enaeavors (Friedman, 1962: 138), while Gellhorn concentrates his research on the expansion of the number of occupations subject to licensing (Gellhorn, 1956: 106).

Gellhorn found that the right to work had been legislated into a "most precarious condition" (Gellhorn, 1956: 105) in all states and many occupations. Not only were traditional professions such as medicine and law affected, but the line between profession and occupation was blurred. 
Historically, professions had been recognized because their "practice was based upon the theoretical study of a department of learning" and "the individuals who follow them are bound to follow a certain mode of behavior and are so regarded by the public" (Gellhorn, 1956: 107). It has become more difficult to say which employment is "learned" and therefore a profession and which is not and therefore an occupation (Gellhorn, 1956: 107). Many occupations are semi-professional, such as nursing, and require the mastery of a large body of knowledge (Gellhorn, 1956: 106). The walls between separate categories have been broken down and instead the difference between profession and occupation has become a difference in degree (Gellhorn, 1956: 108). By 1952, more than eighty separate occupations had been licensed by various state laws (Gellhorn, 1956: 106). The list included threshing machine operators, egg graders, pest controllers, yacht salesmen, tree surgeons, well diggers, tile layers and potato growers; all of these are occupations rather than professions (Gellhorn, 1956: 106). By the latter half of the 1970s, the list had been expanded to include more than 500 licensed occupations (Kleiner, 1982: 383).

Gellhorn found that occupational licensing had rarely been imposed but rather it was induced. Only in rare instances had public recognition of scandalous conditions led to licensing against the wishes of the licensees; 
usually the occupational group lobbied for regulation. The stated reason was to protect the public against so-called incompetent or unscrupulous individuals. The unstated purpose was to receive a competitive advantage or an enlarged income (Gellhorn, 1956: 109).

The pattern of pressure for occupational regulation was similar all over the country; legislation had been enacted on behalf of a producer group (Friedman, 1962: 139). Friedman found it surprising that there were not more licensing laws, rather than less, since the producer groups involved had an intense interest in the specific problems of their trade. Unfortunately, consumers had only a casual interest and were not motivated to go to the legislature to testify against restrictive legislation (Friedman, 1962: 143).

Comparisons of modern occupational licensing and medieval guilds were drawn by both Gellhorn and Friedman. Guilds were originally concerned with the reputations of their members and early standards assured that all measured up to the prescribed norms of reliability. However, by the midale of the fourteenth century, the power of guilds expanded to the point that competition was restrained (Gellhorn, 1956: 113). The guilds had developed organizations with control features designed to protect their members and in time these controls brought the guilds into monopoly positions (Council of state Governments, 1952: 
10). Friedman considered the overthrow of the medieval guild system an indispensable early step in the rise of freedom in the Western world (Friedman, 1962: 135).

\section{Self-Regulation}

The term "self-regulation" was developed to describe the process of self governance by the regulated professions. Self governance of medieval guilds, one of the oldest regulated occupations, was noted as early as the middle ages (Gellhorn, 1956: 118). The governing boards of regulated professions, composed of practicing members of the occupations, set prices, entrance requirements including length of apprenticeship, examination and entrance fees (Gellhorn, 1956: 117).

In a study of twenty-four occupations licensed in various states in 1940 and 1950, Alex Maurizi was able to show a substantial correlation between the passing rates on licensing examinations for new applicants and the excess demand for licensed practitioners in half the occupations he studied (Maurizi, 1974: 412). Maurizi was disturbed by the lack of correlation in the remaining 50 percent of the cases (Maurizi, 1974: 412). He did not allow for the effect of national examinations which did not fall under the control of the individual state regulatory boards. For example, although the examination for accountancy was written and graded as a national examination, Maurizi found correlations for accountancy passing scores and excess 
demand for licensed practitioners significant at the 1 percent level (Maurizi, 1974: 406). Maurizi's study is cited as evidence that state licensing boards alter the pass rate of examinations to control the number of new licensees but his results may not support that conclusion.

Seventy-five percent of the occupational licensing boards were composed exclusively of licensed practitioners in the respective occupations by 1952 (Gellhorn, 1956: 140) . These members made decisions in professions where they had a direct economic interest; they were directly representative of the organized groups with the occupation they were governing (Gellhorn, 1956: 140). There has been concern by policy makers that selfregulating professions set entrance standards too high and have been insensitive to complaints by consumers against their members (Shaked, 1981: 217). The argument is still made to legislators by trade associations that only a board chosen from the regulated occupation can have the technical expertise required for evaluation of license applicants (Fellmeth, 1985: 16; Friedman, 1962: 140).

Avner Shaked and John Sutton developed a mathematical model of self-regulation which indicated that granting of monopolistic powers to the self-regulating professions was likely to result in an economic welfare loss and that permitting the entry of rival paraprofessionals was welfare improving (Shaked, 1981: 233). 
Constitutional Validity

According to the U.S. Supreme Court, the liberty of which one may not be deprived without due process includes: . . the right of the citizen to be free in the enjoyment of all his faculties; to be free to use them in all lawful ways; to live and work where he will; to earn his livelihood by any lawful calling... (Allgeyer v. Louisana, 1897: 578).

Statutes, ordinances and regulations speak to what callings are "lawful." The state cannot, "under guise of protecting the public, arbitrarily interfere with private business or prohibit lawful occupations or impose unreasonable or urnecessary restrictions upon them" (Burns Baking Co. v. Bryan, 1924: 504, 513). These words have little impact as legislatures, not courts, consider whether a measure is reasonably needed to protect the public health, welfare or safety. The Supreme Court has presumed that a legislature had sufficient knowledge to support its judgment that the legislation was in the public interest. Only in rare circumstances would the courts interfere with legislative decisions regarding occupational regulation (Gellhorn, 1956: 119).

Interstate Mobility

Gellhorn stated that licensing laws would soon anchor Americans by local residence requirements as a condition of license eligibility even though these restrictions were not related to public health, safety, or welfare (Gellhorn, 1956: 126). In 1980, Leila Pratt used data from the 1960 
census to study labor migration patterns and concluded that the greater the number of states licensing an occupation, the more restricted would be the mobility of the worker (Pratt, 1980: 79). Morris Kleiner also attempted to measure the effect on migration patterns of state occupational licensing of fourteen occupations (Kleiner, 1982: 383) - Using data from the 1970 census and similar statistical methods to those used by Pratt, Rleiner found that more restrictive state licensing statutes reduced inmigration and were significantly related to increases in the earnings of the persons in the professions (Kleiner, 1982: 383)

Levels of Regulation

To effectively state the case against regulation, Friedman considered it important to clearly distinguish between the three different levels of regulation: registration, certification, and licensing (Friedman, 1962: 144).

Registration is an arrangement under which certain individuals are required to list their names in an official register in order to pursue certain occupations. Registration often includes a requirement that the applicant obtain insurance or bonding (Fellmeth, 1985: 144).

Certification involves an agency which certifies that an individual has certain skills to provide a professional service. Certification, both voluntary and compulsory, can 
lower information costs about a product or service to buyers (Hoskins, 1986: 15). Even if certification is voluntary, it often serves as an intermediate stage in more restrictive regulation. For example, in many states there has been a tendency to restrict an increasing range of activities to certified public accountants (Friedman, 1962: 144).

Finally, licensing restricts the practice of an occupation to those who have demonstrated a competency by examination. Iicensing is "the granting by some competent authority of a right or permission to carry on a business or do an act which would otherwise be illegal" (Council of State Governments, 1952: 5).

Under which conditions could each of these levels of regulation be justified? Registration could be justified for the sake of the information it provided, as a device to facilitate taxation or as a means to protect consumers against fraud (Friedman, 1962: 145). If registration required insurance or bonding, consumers would have the opportunity to collect damages on civil judgments (Fellmeth, 1985: 5).

Friedman found certification more difficult to justify because the private market could efficiently provide information (Friedman, 1962: 146). Gellhorn would opt For certification in many instances to replace licensing (Gellhorn, 1956: 147). 
Gellhorn found licensing a reasonable regulation where the consumer did not possess enough information to choose the person to serve him or her (Gellhorn, 1956: 146). Friedman found licensure unjustifiable because it denied the rights of individuals to enter into voluntary contracts. Licensure could only be justified on the grounds of neighborhood effects. The most obvious example of neighborhood effects is the incompetent physician who produces an epidemic (Friedman, 1962: 147).

The Medical Profession

Friedman used the medical profession as an example of the social and economic cost of regulation to illustrate his point against licensure. Regulation allowed the producer group to obtain a monopoly position (Friedman, 1962: 148). The American Medical Association was the strongest trade union in the United States. It was able to effectively control entrance into the medical profession by controlling admission to approved medical schools and the membership of the state medical licensing boards (Friedman, $1962: 150)$.

Following Friedman's discussion of the monopoly created by the medical profession, a number of authors considered the questions he raised. Chris Paul summarized these studies, stating that economists generally believed that the medical profession earned above normal returns by restricting entry into their profession (Paul, 1982: 559). 
Paul then extended the general theory of regulation to the case of a seif-rigulating profession, the structure of regulation in medicine. Paul presented a model of selfregulatory behavior and tested the model's implications for the medical profession. He found that where licensing boards were controlled directly by the medical profession, physicians' incomes were significantly higher for both years he tested (Paul, 1982: 568). Paul was also interested in the reasons behind the regulation of the medical profession and the resultant quality of medical care. Paul's research found no support for the contention that physicians were initially regulated at the behest of the general population (Paul, 1984: 27). Also his research found no support for the contention that state licensing of physicians improved the quality of medical care (Paul, 1984: 27) .

\section{Restricted Entry and Quality of Service}

Does licensure provide the public with assurance of at least minimum quality? As stated earlier, Gellhorn found that some forms of regulation were useful where the consumer lacked information since one of the traditional elements necessary for the marketplace to function efficiently is sufficient information.

In his study of regulated professions, Hayne Leland questioned the economic justifications for regulating quality. Minimum quality was expressed as a minimum level 
of competence to pass a professional examination (Leland, 1979: 1329). Leland found that markets which had minimum quality standards tended to be characterized by information asymmetry, in which the seller knew the quality of his service or product, but the buyer did not (Leland, 1979: 1329). Quality is defined as quality of services or quality of products (Leland, 1979: 1330). Leland developed a model of markets with asymmetric information and studied the nature of market failure. He found that minimum quality standards in such markets may be socially desirable, but if the professional group was allowed to set the minimum quality standards (self-regulation), these standards may be set too high (Leland, 1979: 1342).

Stuart Dorsey extended these studies to the effect of licensing on the excluded worker. He found that blacks, the less educated and apprentices were more likely to fail licensing examinations even though they did not appear to be less able than other workers who were admitted to the licensed professions (Dorsey, 1980: 424).

Leland continued the modeling of markets with asymmetric information and found that if one firm tried to improve quality in a market lacking information, the consumer had no way to recognize the improvement in quality (Leland, 1979: 1339). Any firm undertaking quality improvements in this type of market would bear the full cost of those improvements. In a market with a large 
number of competing firms, no benefits would accrue to the individual firms and the optimal level of investment in quality improvement would be zero (Leland, 1979: 1339). Thus, he found that a market which should be regulated tended to remain at the lowest level of quality required by the regulatory standards.

Educational Testing Service funded research on the effectiveness of occupational licensing and these studies concluded that the public was often deluded by licensing laws which did not require reexamination or evidence of continued competency (Shimberg, 1973: 33). Persons entering the licensed occupations may need to meet rigid requirements but often did not have to demonstrate that they had maintained their skills. Licenses could be renewed indefinitely on payment of the appropriate fee (Shimberg, 1973, 33).

Further, new licensing legislation often contained a "grandfather clause" which exempted those already practicing and the public had no way of knowing which practitioners were "grandfathers" (Shimberg, 1973: 33).

\section{Conclusions}

Gellhorn concluded that occupational licensing had gone too far; it compressed the economy and stratified society (Gellhorn, 1956: 144). Still, he stated that the abuses of licensing did not entirely obscure its utility; it did afford protection to the public. Occupational 
licensing should save the public from being victimized, not be used as an economic weapon to strengthen the licensees (Gellhorn, 1956: 145). Occupational licensing, then, should be reserved for special cases where the consumer did not possess enough information to choose (Gellhorn, 1956: 146). He also found a second special case for licensing might arise where theoretical training was a necessary step toward achieving occupational competence (Gellhorn, 1956: 146). Following the theory that limited licensing serves the public interest Gellhorn concluded:

In occupational licensing, the choice is not between some regulation and none. The choice is between licensing for the sake of the occupations and, on the other hand, licensing for the sake of the public at large (Gellhorn, 1956: 151).

Friedman took a much more conservative position and summed up the problems of all types of regulations as follows:

The most obvious social cost is that any one of these measures, whether it be registration, certification, or licensure, almost inevitably becomes a tool in the hands of a special producer group to obtain a monopoly position at the expense of the rest of the public (Friedman, 1962: 148).

The discussion of the relative merits of occupational regulation was still continuing during the year of the IRS TCMP study. In an address before the American Enterprise Institute Occupational Licensure Conference in 1979, Michael Pertschuk, Chairman of the Federal Trade Commission, stated that he believed licensing was both a cause of and a response to the problem of quality of services 
in regulated occupations. Licensing allowed the government to step in where consumers were unable to evaluate bundles of diagnoses and services, but it became a vehicle for the dominance and exclusive authority of a profession (Pertschuk, 1979: 34). To illustrate his point on the inability of licensing to ensure competence and integrity of those who offered services, he quoted studies estimating that 33 cents of every dollar spent in 1978 on automobile repairs went for unnecessary work and that two million Americans underwent surgical procedures that were unnecessary at a cost of ten thousand lives and $\$ 4$ billion dollars (Pertschuk, 1979: 34). He also compared the quality of television repairs in Louisiana, where repairers were licensed, to the District of Columbia, where no licensing was present: both areas had the same incidence of unnecessary repairs (Pertschuk, 1979: 35).

The literature review reveals that the marketplace does not always function efficiently and regulation may be warranted but the growth of that regulation has been "haphazard, uncoordinated, and chaotic" (Shimberg, 1972: 1). Government regulation protects the public but also the licensees. Does it increase costs, limit competition, restrict entry and reduce mobility? Most pertinent, what is the effect on quality of services offered? With this introduction to occupational regulation and the reference to the quality of services provided by regulated 
occupations, the discussion turns to the hiscory of the regulation of commercial tax preparers--the occupation to be considered.

THE TAX PREPARATION INDUSTRY

The tax preparation industry is composed of two segments. The first segment is comprised of the commercial tax preparers who are the local and national tax services, bookkeeping services and public accountants. Commercial tax preparers are regulated in two states: Oregon and California. Public accountants are fully regulated in nine states, subject to some regulation in six states and unregulated in the remaining states (National Association of State Boards of Accountancy, 1979: 2). The second segment of the industry is the professional preparers, comprised of the certified public accountants and attorneys. Professional preparers are regulated at the state level in every jurisdiction.

\section{History of the Tax Preparer}

The federal income tax law of 1913 resulted in a progressive tax with low rates based on income which affected only the higher income Americans. Accountants prepared many of the early income tax returns. The first accountancy regulations passed in the United States were "certification" laws only. These statutes restricted the title Certified Public Accountant (CPA) but not the scope 
of accounting practice (Young, 1986: 10). By 1929, the New York State Bar Association's Committee on the Scope and Practice of Law reported that:

The great field of taxation. - has been all but taken over by the accountant fraternity, which seems to have proved itself the more fit to survive in such environment (Griswold, 1955: 131).

As the income tax became broader and more complex, attorneys began to prepare returns and set out to protect their turf, the practice of law, against CPAs and public accountants. By the 1950's, the practice of preparing returns for compensation became much more commonplace and the CPAs and public accountants joined forces to protect their tax practices against attorneys.

Meanwhile, another segment of the industry was emerging: the commercial tax preparer. The commercial preparer, as we recognize the industry today in the form of national tax services, began in 1955 when Henry and Robert Bloch (later changed to Block) expanded their public accounting practice mainly devoted to tax return preparation on a franchise basis across the country. The Internal Revenue Service (IRS) had discontinued the preparation of tax returns for taxpayers in 1954 (Legislative Research, 1982: 1): Raymond Harless, Deputy Commissioner of the IRS in 1973, stated that the reasons for the discontinuance of tax preparation by the IRS had been threefold: increasing number of taxpayers, increasing IRS responsibilities and no increase in agency resources (Harless, 1973: 13). During 
the same time period, the simpler tax forms were discontinued which eliminated the easy methods of filing tax returns for middle-income taxpayers.

Attorneys and CPAs did not have the personnel or interest in filling out the simpler returns and the commercial tax preparers satisfied the increasing demand for inexpensive tax preparation. By 1970, Forbes (Editorial, 1970) reported that commercial tax preparation was a mature industry. H\&R Block had revenues of $\$ 53$ million from preparation of seven million tax returns in four thousand offices across the country. However, problems in the commercial preparer industry were developing: competition, rising costs and inability to acquire and train adequate personnel.

With this expansion of commercial tax return preparation came national attention to reports of negligence and fraud in the late 1960s and early 1970s. By 1971, H\&R Block had grown to five thousand offices (Sager, 1971: 24). The total number of persons preparing tax returns commercially was estimated at 200,000 (Simonetti, 1972: 348). National attention was focused on H\&R Block and Beneficial Finance in 1971 when the Federal Trade Commission accused them of false advertising and illegally using confidential information supplied by customers (Gray, 1971: 555). There was also concern about smaller unscrupulous local tax preparers, the so-called nfly-by-night 
operators," in business across the country. These were preparers who set up store-front tax services during the four-month tax season and then disappeared, often with taxpayers' records and their refund checks (Legislative Research, 1982: 5\}.

Because of the problems, the IRS, using a "shopping technique," initiated studies of tax preparers. An IRS agent posing as a client went to a return preparer with a predetermined set of information for income and deductions together with a cover story about his occupation and family status (Hanlon, 1973: 9). The studies received national attention in 1972 because of erroneous reporting of the findings. It was reported that 60 percent of the returns prepared for undercover agents contained improprieties (Hanlon, 1973: 8). Early reports failed to mention that undercover agents only visited preparers already suspected of incompetence or unscrupulous behavior (Hanlon, 1973: 8). During 1972, the IRS contacted 3,241 tax preparers suspected of incompetence or illegal activities. The IRS expanded the study during the subsequent season to include about six thousand preparers. The preparers contacted during 1973 were not under suspicion of unethical practices. Legal actions were taken against 404 preparers from the 1972 study and 318 preparers from the 1973 study (Hanlon, 1973: 11). 
In summary, the IRS studies indicated that commercial preparers claimed fictitious deductions or increased the number of exemptions claimed to reduce the taxpayer's liability or achieve refunds (Hanigsberg, 1980: 19).

Much was written in national journals in the early 1970 s about the problems in the commercial tax preparer industry. Many of the articles appeared in the National Public Accountant, the journal of the National Association of Public Accountants. The notoriety associated with the commercial tax preparation industry was damaging to the public accountants' image and was another added problem in their losing battle to maintain themselves as a regulated profession.

The largest portion of the commercial tax preparation industry was composed of the local and national tax services. These groups, together with the public accountants, in Oregon and California gathered forces to protect their reputations and called on the state legislatures to regulate the industry.

\section{State Regulation of Commercial Income Tax Preparers}

While hearings were in progress in Washington, D.C., on federal regulation of tax preparers, regulatory laws were enacted in two states. California enacted a registration law and Oregon enacted a licensing law. Regulation of Commercial Tax Preparers in Oregon. Oregon Income Tax Services Law, ORS 673.605 to 673.735 
(1973) contains the regulatory requirements for tax

preparers and consultants. Persons who prepare, advise or assist in the preparation of personal income tax returns must be licensed in Oregon as tax consultants or tax preparers. Only tax consultants may offer their services directly to the public. Tax preparers must work under the supervision of a tax consultant, an attorney, a pubiic accountant or a CPA.

To become a licensed tax preparer, an applicant must be at least age 18, hold a high school diploma, complete an approved 60-hour income tax course, and pass an examination. To become licensed as a tax consultant, an applicant must meet the requirements for a tax preparer, be employed for at least two seasons as a tax preparer and pass another, more difficult examination (Legislative Research, 1982: 4). For license renewal, licensees must submit proof of at least 60 hours of continuing education courses every three years.

History of the Oregon Law. The principal proponent of the original law was the Association of Tax Consultants, an organization formed in 1973 to upgrade the profession through establishment of a state licensing program (Legislative Research, 1982: 11). Sponsors of the legislation cited fraud and negligence uncovered by the IRS studies and erroneous and fraudulent returns found among those prepared by Oregon preparers. The incidence of fraud in oregon returns was not documented (Legislative Research, 1982: 12). 
The legislation contained a "grandfather" clause which resulted in the licensing of 1,789 preparers without examination. This clause drew substantial criticism which nearly defeated the legislation. The law was amended slightly in 1975 and 1977. The legislative minutes relating to the amendments show continuing concern that the law was protecting members of the industry from competition rather than protecting consumers from incompetent preparers (Legislative Research, 1982: 14).

The Oregon State Board of Tax Service Examiners, composed of five members of the profession, prepares, administers and grades examinations for preparer and consultant applicants (Legislative Research, 1982: 27). Some assistance in preparation and grading was obtained from Oregon universities, but as of 1982, the licensing examinations still had not been formally validated (Legislative Research, 1982: 19).

During the period from 1973 through June 1982, the Board considered 938 consumer complaints. The most common consumer complaints were for poorly prepared returns, excessive fees, failure to return clients' records, and inability to locate licensees after tax season (Legislative Research, 1982: 23). Action taken by the Board against tax consultants included eight fines ranging from $\$ 250$ to $\$ 1,000$. Also, a total of $\$ 9,200$ had been assessed against 25 persons found guilty of preparing income tax returns 
without a license, representing 60 percent of the penalties assessed (Legislative Research, 1982: 25).

In September of 1982, the Oregon Board of Tax Service Examiners was reviewed as a part of an ongoing "sunset" review process. Oregon's "sunset" law terminates a regulatory agency unless that agency has demonstrated "a public need for its continued existence" (ORS 182.625). According to the Board, licensing was necessary to insure "improved and more competent tax service" (Legislative Research, 1982: 30 ).

During the 1982 review; officials of both the state Department of Revenue and the District Office of the IRS sent letters in support of state regulation of commercial tax preparers. No quantitative data was offered in connection with the review since the information provided by taxpayers on tax returns is confidential, and regulatory agencies, such as the Board, did not have access to tax returns to evaluate the performance of their licensees. As a result of the 1982 "sunset" review, the Oregon State Board of Tax Service Examiners continueä as the regulatory board for the commercial tax preparation industry in Oregon. Regulation in California. Under the legislation enacted in 1973 in California, tax preparers were required to register with the state's Department of Consumer Affairs (California Business \& Professional Code Sections 9891-9891.44, repealed 1982). There were no educational or 
examination standards but preparers had to deposit a $\$ 1,000$ bond and renew registrations regularly (Legislative Research, 1982: 9).

A study of tax preparer regulation in California was commissioned in 1976 by the Consumer Affairs Department and in 1978 the Consumer Affairs Department made an extensive study of occupational licensing, including a case study of the tax preparer program. The study recommended the program be "sunsetted" since the registration program, while "administered with diligence," had only "a minimal capacityn to protect consumers or upgrade the quality of the profession (California Department of Consumer Affairs, 1978 : $B-9)$.

In 1977, a bill establishing a licensing board and requiring examinations passed the California legislature but was vetoed by the governor (Legislative Research, 1982: 9). Funding for California's tax preparer program was discontinued in 1981; the law was repealed June 30, 1982 (Legislative Research, 1982: 9).

Tax preparers were again regulatea in California by the end of 1982. Section 9891, California Business and Professions Code required registration and bonding (increased to $\$ 2,000$ ) of all commercial tax preparers. Every person wishing to register as a tax preparer had to be at least 18 years old and either possess a high school diploma or equivalent. This legislation required the 
applicant to show proof of 20 hours of continuing education each year for reregistration. The law was revised in 1983 to sperifically exempt any person regulated by the California state Board of Accountancy, members of the state Bar of California and any person enrolled or authorized to practice before the Internal Revenue Service. Minor revisions to the regulatory statutes were enacted in 1985 and 1986, and as of the current date commercial tax preparers are required to register in California.

\section{Research on Quality of Tax Return Preparation}

Hearings at the federal level resulted in the request for a study of the quality of tax returns prepared by both commercial and professional return preparers.

Federal Research. The 1975 report to Congress by the Comptroller General (quoted as General Accounting office report) concluded that there was no apparent need to regulate commercial income tax preparers at the federal level. The conclusions were based on a study made of 1971 tax returns filed in 1972 and data collected from approximately five thousand individual 1972 and 1973 tax returns audited by IRS examiners in six districts (General Accounting Office, 1975: 3). The 1971 returns were from the sample of returns selected for the Taxpayer Compliance Measurement Program and the 1972 and 1973 returns were chosen from returns audited in the normal course of operations in the six. districts. 
The report classified public accountants as professional preparers with CPAs and attorneys and aggregated the remainder of preparer types as commercial preparers (General Accounting Office, 1975: 4).

The report analyzed low- and medium-income nonbusiness tax returns, Schedule $\mathrm{C}$ low-income business returns and Schedule $\mathrm{F}$ low-income farm business returns. About 70 percent of all commercially and professionally prepared returns fell into these four categories (General Accounting Office, 1975: 5).

Commercial preparers were responsible for 28 percent of the returns while professional preparers completed 25.4 percent of the returns (General Accounting Office, 1975: 6). The average error for commercially prepared returns was $\$ 156$ representing an average 14 percent change in the amount of tax (General Accounting Office, 1975: 6). There was not a significant difference between the errors made by the different types of tax preparers on the types of returns analyzed; therefore, the conclusion was drawn that federal licensing of commercial tax preparers was not needed (General Accounting Office, 1975: 20). Tax preparer penalties applicable to all types of tax preparers were recommended (General Accounting Office, 1975: 20) and later enacted as part of the 1976 federal tax legislation. The General Accounting Office report did conclude that there was no apparent need to regulate commercial tax 
preparers at the federal level but addressed the issue of the lack of data. The conclusion called for further research on performance wher the data from Oregon and California's regulation of commercial tax preparers would be available to estimate the potential benefits of state regulation (General Accounting Office, 1975: 20).

California Tax Preparer Research Project. In 1976, the California Department of Consumer Affairs cominissioned a study of commercial tax preparation in California by a regional research firm. A sample of 477 preparers was visited using the "shopping" technique of the 1972 and 1973 IRS studies. The research firm found that:

1. Ninety-nine percent of the returns were inaccurately prepared although registered preparers were more accurate than unregistered preparers. Almost three-quarters of the returns reported a higher liability for the taxpayer than was necessary (Kaplan, 1976: 11).

2. Accuracy was directly related to the simplicity of the applicable tax regulation (Kaplan, 1976: 11).

3. Almost half of the test returns did not contain all necessary forms or all requested informational items (Kaplan, 1976: 21).

4. While returns were incorrectly prepared, there were no widespread fraudulent practices (Raplan, 1976: 32).

5. More than 80 percent of the sampled preparers were registered with the California Tax Preparer Program (Kaplan, 1976: 40).

6. Overall, franchise preparers (example: H\&R Block) performed better than independent tax or bookkeeping services (Kaplan, 1976: 43). 
Their findings suggested that:

not even have a fifty-fifty chance of obtaining a
complete, accurate income tax preparation which
reflects their minimum liability under applicable
tax regulations (Raplan, 1976: coves letter).

Federal Regulation

While regulatory statutes brought state regulation of commercial tax preparers in Oregon and California, Congress was considering legislation at the federal level regulating the preparation of federal income tax returns.

In 1974, several bills were introduced in Congress relating to licensing or regulation of commercial tax preparers. The General Accounting Office study indicated that there was not any significant difference in the error rate between professional and commercial preparers, which brought about far-reaching regulation of all tax return preparers.

\section{The 1976 Tax Legislation}

Congress sought to solve the problems uncovered by the IRS studies in 1972 and 1973 with the legislation enacted in 1976. The provisions of the Tax Reform Act of 1976 (P.L. 94-455) marked a significant change in requirements for tax preparers. Prior to 1976, preparers were required to sign returns; however, there was no penalty if the preparer failed to sign. Criminal sanctions had been available only if the preparer acted in a willful or 
intentional way so as to produce a fraudulent return. The preparer could then be assessed criminal fraud penalties but the burden of proof was so strict that criminal penalties were reserved for only the worst offenders. The 1976 tax legislation brought the followins requirements and penalties. The Tax Reform Act defines preparers and makes them liable for negligence penalties of $\$ 100$ and willful understatement penalties of $\$ 500$ per return if any understatement of liability is due to the negligence or willful misconduct of the tax preparer (IRC Sec. 6694). The preparer must provide an identification number on all returns (IRC Sec. $6109(a)$ ), furnish a copy of the return to the taxpayer and keep a completed copy of the return or a list of returns prepared (IRC Sec. 6107). These requirements became effective for documents prepared after December 31, 1976 (Tax Reform Act, 1976: Sec. 1203(j)).

Recent Research

Research in the last ten years deroted to various topics indirectly related to state regulation of tax preparers has included several projects on tax compliance. A study by Charles clotfelter is significant because he used 1969 Taxpayer Compliance Measurement Program (TCMP) data filesl--an earlier sample similar to the data base for

\footnotetext{
$l_{\text {Recent }}$ research has been based on the 1969 TCMP files because this data represents the most current information available. Availability of current data is restricted by Congress, even to the point of limiting its own access (wilson and Smith, 1984; 295).
} 
this study. Clotfelter discusses the relative merits of the TCMP data as follows:

The obvious advantage in using TCMP data is the opportunity to observe personal tax-reporting behavior rather than having to rely on indirect measures or self-reported compliance behavior. In addition, the TCMP data include rich information on income and tax items (Clotfelter, 1983: 367).

Clotfelter also refers to the problems encountered in survey research such as Robert Mason's study of tax evasion in Oregon (Mason, 1981). The problems arise because:

In order to explain tax evasion empirically, most studies have relied on indirect measures of evasion, principally surveys asking about past evasion or about attitudes toward evasion. The validity of such studies, of course, depends on the degree to which the pattern or survey responses corresponds to actual behavior (Clotfelter, 1983: 364).

Robert Mason's research is pertinent because it was conducted in Oregon during 1980 although it does not investigate tax compliance related to the type of preparer. In 1980, Robert Mason and Helen Lowry conducted a survey of 800 Oregon adults to investigate tax noncompliance. of those interviewed, 26 percent admitted cheating on their state income taxes in 1979 (Mason, 1981: 5). Mason also. found that over 5 percent of the respondents failed to file a tax return in 1979 when they felt they should have filed. Later research at the national level using the same format as Mason's obtained similar results.

In 1984, Yankelovich, skelly and white completed a study of taxpayer attitudes for the IRS. A portion of their study is a replication of Mason's study and uses 
2,200 personal interviews across the United States.

Cheating on their tax returns was reported by 19 percent of the taxpayers interviewed (Yankelovich, 1984: 29). This study also reporteả cheating by region and found that 24 percent of taxpayers in the western region reported cheating on their taxes. Although the second study was completed four years later and differences could be attributable to the time lapse, the results match Mason's quite closely (Yankelovich, 1984: 89).

\section{Current Opinions}

While there has not been any research in the past ten years to investigate the impact of state regulation on the quality of tax return preparation, it is worthwhile to note that opinions on the topic have been voiced by informed observers.

In a letter to the Oregon state Board of Tax Service Examiners, Ralph Short, then Director of the IRS District Office in Portland, stated that:

While we cannot support our views with any kind of statistics, the consensus of the affected division chiefs is that the skills of the tax return preparers have improved and the quality of the tax returns filed during the period following the effective date of the Oregon licensing law has generally improved (Gadarowski, 1977: 536).

In 1986, in his co-keynote address to the combined members of the American Institute of Certified Public Accountants (AICPA) and the National state Boards of 
Accountancy, Herman J. Lowe, Chairman of the AICPA Board of Directors, voices a different opinion:

There is no compelling need for licensing and regulation of persons offering record-keeping and elementary accounting services . . . Nor is licensing required in connection with the preparation of tax returns because of regulatory and disciplinary authority presently possessed by the Internal Revenue service and other tax authorities (Lowe, 1986: 54).

The issue is far from settled; research using the Taxpayer Compliance Measurement Program. (TCMP) data may significantly add to current knowledge. 
Taking note of the divergent opinions reported in the previous chapter, the hypothesis of this research is that state regulation of commercial income tax preparers should improve quality. Quality will be defined relative to the magnitude of errors detected during the Taxpayer Compliance Measurement Program (TCMP) examinations. Regulated preparers are subject to testing and education requirements. If state regulation of preparers is effective, the quality of their work should result in a lower magnitude and rate of errors on the returns they prepared during the 1979 tax Eiling season.

THE NULL HYPOTHESES AND THEIR ALTERNATIVES

In order to statistically test the null hypotheses, three groups of errors from the 1979 cycle of the TCMP examinations are analyzed. These groups are chosen to test the integrity and competency of the preparer. In addition, the effect of regulation on the total tax return is evaluated. 


\section{Integrity of Commercial Preparers}

The integrity of commercial preparers has been a concern of the Internal Revenue Service (IRS) for some time (Gadarowski, 1977: 533). During the early 1970s, the IRS attempted to determine the extent of errors made by commercial preparers by sending agents to suspected tax preparers with prearranged tax return information. Using the technique known as "shopping," the tax preparers were engaged to complete a tax return for the agent disguised as a middle-income taxpayer (Harless, 1973: 15). Items on thest: tax returns used to test the ability and honesty of the tax return preparers were number of dependents, unreported and under-reported tip income, medical expense deductions and charitable contributions (Harless, 1973: 15).

If state regulation of commercial tax preparers affects the quality of the return preparation, differences in the items examined earlier by the IRS should also be noted in the 1979 TCMP examinations.

Null Hypothesis I. The error rates or amounts in regulated states are not significantly smaller than those in nonregulated states on items chosen to test the integrity or ability of commercial income tax preparers.

Alternate Hypothesis $I$. The error rates or amounts in regulated states are significantly less than those measures in nonregulated states.

Competency of Commercial Preparers on New Tax Items

During 1977 and 1978, tax legislation was enacted which changed the treatment of items on the 1979 tax 
return. The items which affected a broad segment of middle-income taxpayers who traditionally have their returns prepared by commercial preparers were capital gains calculations, individual retirement accounts, residential energy credits and earned income credits (Aronson, Greene, Fisher and Co., 1979). At the same time, Oregon's regulation of commercial income tax preparers incluāeã requirements for continuing professional education for relicensure.

If state regulation, including Oregon's special requirement for continuing professional education, is effective, preparers in Oregon should be more aware of the tax treatment, and the error rate in these new items should be lower for Oregon's commercial preparers.

Null Hypothesis II. The error rates or amounts on Oregon's returns are not significantly smaller than those from nonregulated states related to items on the 1979 returns which were new that year.

Alternate Hypothesis II. The error rates or amounts in Oregon are significantly less than those measures in nonregulated states.

\section{Competency of Commercial Preparers on Troublesome Items}

Some areas of income tax law are more troublesome for taxpayers than others, either from a record keeping standpoint or because of the complexity of the tax law. Casualty losses, moving expenses and income averaging calculations have been ongoing problems for taxpayers. Income from farming and self-employment also generates 
large differences on many returns (American Institute of Certified Public Accountants, 1979).

If education, licensing examinations and continuing professional education improve the quality of services offered by the commercial tax preparers, the error rate on these areas should be lower in regulated states.

Null Hypothesis III. The error rates or amounts in regulated states are not significantly smaller than those in nonregulated states related to items which have continually caused problems for middleincome taxpayers.

Alternate Hypothesis III. The error rates or amounts in regulated states are significantly less than those measures in nonregulated states.

\section{Cumulative Effect of Total Errors on Tax Returns}

Tax returns contain many sources of income, adjustments and deductions. Only a few of these sources were chosen for evaluation in the preceding tests. This test is designed to evaluate the cumulative effect of all the errors on returns prepared by commercial income tax preparers.

If state regulation of commercial income tax preparers affects the quality of the total tax return, differences should be more evident as the amounts are accumulatea into totals for each of the three sections of the tax returns.

Null Hypothesis IV. The error rates or amounts in regulated states are not significantly smaller than those in nonregulated states on amounts related to the totals for income, adjustments or deductions. 
Alternate Hypothesis IV. The error rates or amounts in regulated states are significantly less than those measures in nonregulated states.

Differences in Levels of Regulation of Commercial Preparers

Studies in occupational regulation indicate that regulation of employment should be the least restrictive form capable of obtaining the desired effect (Friedman, 1962; Gellhorn, 1956). The state of California registers commercial tax preparers and requires posting of performance bonds to protect consumers. This type of regulation represents a least restrictive form while the regulation in Oregon represents the more restrictive form. Oregon requires that the commerical preparer pass two examinations, work under the direction of a licensed preparer and complete continuing professional education for relicensure.

If the type of state regulation affects the quality of tax return preparation, a difference in the error rates should be evident between California and oregon.

Null Hypothesis $V$. The error rates or amounts in oregon are not significantly smaller than those in California in the hypotheses listed above.

Alternate Hypothesis $V$. The error rates or amounts in Oregon are significantly less than those measures in California.

\section{METHODOLOGY LIMITATION}

The validity of any inference procedure in statistics is dependent on the assumption that a random sampling 
procedure is followed. This assumption is clearly valid for the data obtained from the TCMP files. With the random sampling procedure followed by the IRS, descriptive measures are dependable but inferences are limited since the aggregate form of the data prevents the calculation of measures of dispersion (standard deviation, variance or range) .

The sample size is large enough to assume normality of a sampling distribution of means, but without measures of dispersion for each state, that assumption is not usable. The TCMP files disclose information from income tax returns that is not available from any other source. Since this information is in an aggregate form, nonparametric statistical tests were used for analysis. 
CHAPTER IV

DATA DESCRIPTION AND ANALYSIS METHODOLOGY

The Taxpayer Compliance Measurement Program (TCMP) files provide the data for analysis. TCMP is an Internal Revenue Service audit program that is used to estimate how well taxpayers are complying with the income tax laws. The Program thoroughly audits a scientifically selected sample of individual returns. The information obtained by the TCMP examinations of a random stratified sample of 55,000 tax returns from 1979 was analyzed to determine if state regulation of commercial income tax preparers affects the quality of income tax returns.

\section{THE DATA SOURCE}

Data were collected by the Internal Revenue Service (IRS) during 1980 as part of the 1979 cycle of the Taxpayer Compliance Measurement Program (TCMP). The IRS uses information developed from the TCMP data to measure the levels of compliance, to determine changes in compliance levels over time, to improve the procedures used to select returns for audit and to improve the effectiveness of enforcement operations. 
The 1979 cycle of the TCMP examinations is the most recent time that questions were included regarding the type of tax preparer that prepared the tax return. Tax return preparation was classified in thirteen categories. of these thirteen, four relate to commercial preparation of tax returns: public accountants, local tax services, national tax services and other paid preparers. To complete the analysis, a copy of one of the eight data tapes resulting from the 1979 cycle of the TCMP was obtained from the California Institute of Technology in Pasadena with the permission of the Washington, D.C., office of the IRS in May 1988.

\section{DESCRIPTION OF THE DATA}

The total sample size for the TCMP examinations for 1979 was 54,565. The data tape developed from the TCMP examinations contains 1,508 records. It is arranged with the data sorted by fifty-eight districts and by thirteen tax preparation codes. The tape provided for this study is sequentially recorded in the following manner. The major sort is district number. The minor sort is tax preparer code. Within the tax preparer code there are two records, one for total value and one for total frequency of returns prepared.

The data are arranged on the tape as they were taken from tax returns and supporting schedules. The tax return, 
for purposes of this study, is the unit representing the taxpayer. The analysis will be of data taken from Form 1040, the U.S. Individual Income Tax Return, and Schedule A, Itemized Deductions. A data point is available for each line of Form 1040 and schedule $A$ filed by the taxpayer and reviewed by the IRS examiner.

\section{PREPARATION OF THE DATA}

The magnitude of an error on the tax return is measured by taking the total dollar value of the difference between the line item as filed and the line item as examined and dividing by the number of observations. This mean difference, expressed in dollars, may be affected by the size of income for taxpayers in the different states. To adjust for this effect, the mean dollar amount of difference is normalized by dividing by the total income for that group of taxpayers. This expresses each mean change as a percentage of total income by each group.

All the calculations above were done for each preparer type except for exemptions. The change in exemptions between the number as filed and the number as examined was restated as a dollar value by multiplying the mean change by $\$ 1,000$, the value of an exemption in 1979 .

The total observations for each preparer type by district were summed for states with multiple districts 
such as New York, Texas and California. By summing the observations and values for these states at this point, it was possible to accurately weight the data in the next step of the analysis.

THE MODEL TAX RETURN

Weighted means for each data point were obtained using SAS statistical routines for each line item on the 1040 form and Schedule $A$ as filed and as corrected during the TCMP examination using the following procedure:

1. The mean for each of the $R$ line items is determined. Let these means be:

$$
\overline{\mathrm{Y}}_{1}, \overline{\mathrm{Y}}_{2}, \ldots ., \overline{\mathrm{Y}}_{\mathrm{K}} \text {. }
$$

Let the sample sizes be:

$$
\mathrm{N}_{1}, \mathrm{~N}_{2}, \ldots, \mathrm{N}_{\mathrm{K}} \cdot
$$

2. Compute the weighted average as:

$$
\bar{Y}=\frac{N_{1} \bar{Y}_{1}+N_{2} \bar{Y}_{2}+\ldots .+N_{K} \bar{Y}_{K}}{N}
$$

where $N=\sum_{i=1}^{R} N_{i}$.

Let $w_{i}=N_{i} / N$ (for $i=1$ to $\left.K\right)$.

Then: $\overline{\mathrm{Y}}=\mathrm{W}_{1} \overline{\mathrm{Y}}_{1}+\mathrm{w}_{2} \overline{\mathrm{Y}}_{2}+\ldots+\mathrm{W}_{\mathrm{K}} \overline{\mathrm{Y}}_{\mathrm{K}}$

$$
=\sum_{i=1}^{K} w_{i} \overline{\bar{Y}}_{i} \text {. }
$$


The file was then exported to a personal computer and a macro was set up in a spreadsheet program (Quattro) to aevelop model tax returns for each preparer type in each district using the weighted means for each line of the return. These models of hypothetical tax returns were used to make preliminary examinations of the data, providing an opportunity to consider the magnitude of errors on returns from various states and tax preparer types. of the thirteen tax preparer types, four types of preparers constitute the commercial segment of the preparer industry. The four types of commercial tax preparers and sample sizes are shown in Table I. These four types of preparers are the preparers of primary interest for the study.

TABLE I

COMMERCIAL TAX PREPARER TYPES

Preparer Type

National Tax Services Local Tax Services Public Accountants

Other Paid Preparers

Sample size
Sample size

$$
4.071
$$

7,290

5,290

4,232

20,883

For comparison purposes, in addition to the commercial segment, model returns were prepared representing 
professional tax preparers (Certified Public Accountants (CPAs), attorneys and attorney-CPAs) and self-prepared returns.

STATISTICAL METHODS OF ANALYSIS

A variety of charts and graphs was prepared describing the data in a manageable and comprehensive fasinion in order to highlight important observations.

Descriptive Statistics

Density Stripe Graphs. Density stripe graphs picture the distribution of the magnitude of the errors. Vertical lines are placed at the location of data values on a horizontal data scale. These representations are especially well suited to small- to medium-sized samples of continuous data (Wilkinson, 1988: 344).

Ranking the states. The states are ranked by the magnitude of error on total income, adjustments and deductions. By considering totals, the problem of missing data points is eliminated and the states can be ranked without misinterpreting the results. However, in Hypotheses I through III, missing data points provide for misrepresentation of the totals. Since a missing value is treated in the same manner as a zero change, from the original filing to the examination, it would mistakenly indicate no error either by the taxpayer or the preparer. A missing value 
should indicate that that tax preparer did not deal with that item on tax returns in that particular state. At the point that totals for income, adjustments and deductions are being evaluated, the data for each tax preparer type indicates that each preparer has prepared a return with at least one item of each category.

\section{Cluster Analysis}

Data are available from each of the fifty states within the United States. The object is not to generalize beyond these states, but to make inferences about the causal processes that may have generated the data. There may be significant differences between several of the states due to variations other than the type of tax preparers. To assist in isolating the differences between states which might result from variations within the populations of the states, cluster analysis was used.

Cluster analysis was used to detect natural groupings among the states. To assist in determining the differences due to abilities of the commercial tax preparers, the states were grouped by other taxpayer characteristics. The attributes used to determine clustering were "magnitude of errors" and "IRS compliance activities for each state."

The magnitude of errors was measured by the total change during the TCMP examination in mean income, adjustments, deductions, and taxes for returns classed as 
self-prepared. The differences were adjusted to a percentage of mean income to reduce the effect of variations in income levels among the states. The data from the selfprepared returns were chosen because commercial or professional tax preparers, other than the taxpayer, were not involved in filing the returns. This eliminated the issue of occupational regulation. Information from the selfprepared returns was used as a surrogate for the compliance of a representative group of taxpayers within each state. In addition to clustering the states to isolate the current differences among the taxpayers, the literature review indicated that clotfelter had observed some regional differences in his analysis of the 1969 TCMP data. He found that compliance was highest in the New England states with good compliance extending south to virginia and Rentucky and west to Indiana and Michigan. The sunbelt had the highest rate of underreporting on non-farm returns. The Midwest and Southeast had the most underreporting for farm returns (Clotfelter, 1983).

Research by witte and Woodbury using the TCMP files had alsoindicated that compliance activities by the IRS influences the behavior of individual taxpayers. Witte used the 1969 TCMP data to model U.S. Federal income tax compliance and found that the probability of audit influenced the level of tax compliance (witte and Woodbury, 
1985: 2). Audit risk for this analysis was obtained by using the percentage of returns audited per state from the 1979 filing season using the figures from the Annual Report of the Commissioner of the IRS for 1981 .

Witte also found that IRS compliance activities, such as IRS data processing efforts, had significant effects on compliance (Witte, 1985: 9). Surrogates for IRS compliance activities, used for this analysis, were the mean dollar amount collected per return audited and the cost of administration by the IRS per return filed. These amounts were also obtained from the Annual Report of the Commissioner of the IRS for 1981 .

Nonparametric statistics

Nonparametric tests were used for this analysis because these procedures do not require any assumption that specifies the exact distributional form of the population. A parametric difference of means test would ordinarily be more powerful than the nonparametric methods. However, because of the lack of a standard deviation, a difference of means test is not appropriate. The data can be measured on a ratio scale to permit reliance on comparisons between nonparametric methods.

Model of the Differences. When two samples are shifted apart by a quantity that represents the difference between some location parameters, the theoretical 
representation of the model is $F_{R}(\Delta Y)=F_{N R}(\Delta Y+\theta)$ for all $Y$ where $R$ represents regulated states, NR represents nonregulated states, $F_{R}$ is the Eunction for the $R$ population, FNR is the function for the NR population, and $\theta$ is a constant representing the amount of shift. If $\theta$ equals zero, $R$ and NR are identically distributed and the hypothesis of similar populations is true. If $\theta$ is positive, the variables in the NR population tend to be larger than those in the $R$ population. A negative $A$ indicates the values in the NR population tend to be smaller than the $R$ population (Gibbons, 1976: 159). Nonparametric methods were used to test the model. The location shifts measured are the cumulative distribution and medians. Three tests are applied to the data. Each of these tests is discussed in detail. The Rolmogorov-Smirnov Test. This two-sample test requires the assumption of independent random samples measured on at least an ordinal scale. The test measures differences in cumulative frequency distributiono If there are no significant differences between the samples drawn from the different states, the cumulative frequency distributions from the two populations should be essentially similar. The test statistic is the maximum difference between two cumulative distributions. The statistic can also be defined for the general hypothesis of similar distributions but with an alternative that states a directional difference between the two populations. 
The Sign Test. The sign test requires the same assumptions as the Rolmogorov-Smirnov test. It is computed for pairs of variables. The sign test for location is applied to the paired sample data by taking the difference of each pair. The difference between values on each observation is calculated and the number of positive and negative differences is recorded. The lesser of the two is then compared to the total number of differences. The probability, when the null hypothesis is true, of obtaining a value which is equal to the observed value is computed. The sign test uses some of the information generated about paired observations but does not consider the magnitude of those differences.

The Matched Pair Wilcoxon Test. This test treats the sample differences with weights correlated with the magnitude of each individual difference. The assumption is that the data are taken from independent random samples measured on at least an interval scale.

To complete the wilcoxon test, the difference score for each pair is obtained. The differences are then ranked and numbered according to their absolute values. Next the signs of the differences are attached and the ranks of both the positive and negative differences are summed. If the null hypothesis is correct, the sum of the ranks of the positive differences should not be smaller than the sum of the ranks of the negative difference. 
Comparison of Nonparametric Methods. The Wilcoxon test should give much better performance than the sign test since it takes advantage of substantially more information (Gibbons, 1976: i42). The sign test uses only information about the direction of the differences between members of a pair and the hypothesized median, while the wilcoxon test also uses the magnitude of each difference relative to every other difference (Gibbons, 1976: 141).

The assumptions of the student's $t$ test cannot be verified with the TCMP data, but if they were actually true, the power efficiency of the wilcoxon test is approximately 95 percent for both small and large samples. The wilcoxon test is especially useful in situations where the sample size is too small to justify the normality assumption (Blalock, 1979: 270).

These two nonparametric test procedures are applicable to data representing differences of paired observations. In each case, the variables must be independent. Inference concerns values of population medians. The data must be on an ordinal scale with a population assumed to be continuous for the sign test and symmetrical for the signed rank test. Gibbons (1976: 142) states that:

In most situations, the signed rank test should be used in preference to the sign test when the assumption of a symmetric distribution appears tenable and the data are measured on a sufficient level of precision. 
Both, tests are nonparametric counterparts to the student's $t$ test for means. The student's $t$ test is based on the assumption of a normal distribution which is much more stringent than the assumption of symmetry.

In comparing the power of the tests, the asymptotic efficiency of the signed rank test relative to student's $\underline{t}$ test is not smaller than .84 while the sign test may be only .33 (Gibbons, 1976: 142). These values apply to large samples; in small samples from nonnormal distributions, these nonparametric tests may be more powerful than student's $t$ test (Gibbons, 1976: 143).

The Kolmogorov-Smirnov test is more difficult to evaluate. It is a good test for a general null hypothesis of identical distributions. It is a general test which is somewhat sensitive to all kinds of differences between populations but not particularly sensitive to any specific type of difference (Gibbons, 1976: 262). While the Kolmogorov-smirnov test does not take advantage of the information available by pairing the observations, it is particularly useful where a location difference is the primary interest (Gibbons, 1976: 254). 
CHAPTER V

RESULTS

The results of the descriptive statistics are presented below for the model tax returns along with various charts and graphs. The results of the nonparametric statistical comparisons anong oregon, California and the nonregulated states are presented in the second section for each of the hypotheses.

\section{DESCRIPTIVE RESULTS}

The data for each state, for each commercial tax preparer type, were prepared for statistical analysis as shown in Appendix B for Oregon and California. The values represent mean differences between the line items from the returns as reported and as corrected during the TCMP audits. These mean differences or changes are shown as dollars and also restated as percentages of income for each preparer type.

Totals for each hypothesis were determined for reference, but not included in the statistical analysis. Missing values, expressed as decimal points in the tables, indicate that the preparer did not encounter the tax item 
in that state. This problem was more predominant in the states with smailer populations. The zeros represent no change for a particular item.

\section{Model Tax Returns}

Weighted means for each point were obtained to prepare model tax returns (shown in Appendix B) to be sure the calculations produced reasonable totals. The number of data points used in the study was scaled down to produce model returns containing the larger items encountered by most preparers in most districts. Items which accounted for smaller dollar values and not of interest for this study were not used. Income from prizes was such an item.

The IRS divided tax preparers into thirteen types for their study. Four types, IRs assistance only, IRs reviewed, IRS preparation and VITA/TCE assisted, accounted for a total of only 590 of the 54,565 observations. These types were not of interest and contained many missing dita points and so were not used. The first return was prepared from the total sample. The second return was prepared after the 590 observations were deleted. The latter indicates that the magnitude of the changes is slightly higher representing differences of less than 1 percent because of the deletions. 
Comparison by Preparer Type

The model tax returns were prepared to compare commercially prepared returns to self-prepared and to professionally prepared returns. Differences among preparer types in income levels and in error rates are indicated in the results. The highest average total income levels of $\$ 29,700$ are shown for professionally prepared returns. Average total incomes for commercially prepared returns are $\$ 16,600$ while incomes for returns prepared by taxpayers are lower at $\$ 13,400$. Changes in income were also compared among tax preparer types. The highest average changes are shown for professionally prepared returns. Changes in stated income for professionally prepared returns are indicated as over 6 percent compared with 4 percent for commercially prepared returns and less than 2 percent for self-prepared returns. Considering the higher change in income, it is interesting to note that the changes in interest and penalties are still lowest for the professionally prepared returns.

There has been very little published research which used the TCMP files as primary data, so there are limited comparisons to be made with prior studies. Clotfelter used the 1969 TCMP files to study tax compliance. A table from the Appendix to his publication forms the basis for comparison of reported amounts versus examined amounts from the 1979 TCMP data (Clotfelter, 1983: 373). The magnitude 
of changes is compared among all preparers, all commercial preparers and commercial preparers in regulated states in Table II.

\section{TABLE II}

COMPLIANCE BY TYPE OF INCOME, DEDUCTION AND TAX: SUMMARY RATIO OF TOTAL REPORTED AMOUNTS TO TOTAL CORRECTED AMOUNT

Al1

Tax Item

Preparers $\underline{1969 \quad 1979}$

Commercial Preparers

Wages

Dividenas

$1.000 \quad .997$

$.975 \quad .941$

Interest

$.983 \quad .961$

Rents

$.721 \quad .556$

Capital Gains (D)

Proprietorship (C)

Farming (F)

$.941 \quad .898$

$.830 \quad .758$

$.635 \quad .345$

$.772 \quad .624$

Adj. Gross Income

$.975 \quad .964$

Tax

$.938 \quad .918$

1.0231 .039

Exemptions

Adjustments

Total Deductions

1.1051 .134

Contributions

1.0921 .058

$1.168 \quad 1.094$ Total oregon California

*The reported amounts were negative, indicating losses.

In Table II shown above, a ratio of less than one means that" the reported amount is less than the corrected amount. The results from the sample indicate that taxpayers as a total group reported a smaller percentage of income and taxes in 1979 than taxpayers did in 1969. The results from the sample of the returns prepared by commercial preparers indicate that this group reported a smaller percentage of income and taxes than the total sample for 1979. Restating the results, the differences between the 
items as filed and the items as examined are larger for commercial preparers than for the total sample in 1979. Comparing the commercially prepared returns in regulated states with the nonregulated states, the results indicate that the error rates were smaller in Oregon than the total of all commerically prepared returns. The results from California indicate that the error rates were larger than the average for all commercially prepared returns.

Model tax returns were prepared to represent commercially prepared returns in a number of states other than Oregon and California. These are also presented in Appendix B. Changes in income varied from a low of 2 percent for Oregon to 21 percent for New Mexico. The differences among the income levels on commercially prepared returns was also of interest. The average reported income shown on commercially prepared returns ranged from a low of $\$ 10,600$ for New Mexico to $\$ 20,600$ on returns from Hawaii. This range was wide enough to confirm the necessity of restating the dollar changes as percentages of income in the statistical evaluations.

Changes in adjustments ranged from 2 percent of the total for Virginia to 30 percent for North Dakota. Changes in deductions did not vary as widely, ranging from 2 percent through 8 percent.

In evaluating the changes in deductions, it became apparent that the effect of some of the errors was 
cancelled due to errors in the opposite direction. For example, income would be expected to increase on examination by the IRS and the reverse should be true for deductions. In reviewing the sample for Nebraska and New Mexico, it was concluded that changes did not consistently follow this pattern. To reduce the bias caused by positive errors tending to cancel negative errors, all errors were expressed as absolute values for the statistical tests.

\section{Graphic Representations of the Data}

Density stripe graphs of selected states were prepared to evaluate patterns in the errors made by commercial preparers and are presented in Appendix $C$.

The pattern of the mean errors on Oregon's returns is compared with those from the New England states. The values are the mean total errors, expressed in dollars, in income, adjustments and deductions. This data is also totaled and presented in the bar graphs ranking the states. The largest average error comes from a $\$ 1,200$ understatement of total income in the sample from Rhode Island. Rhode Island's sample appears among those states with the lowest errors due to a large number of missing values in the sample. The information available from this sample is limited due to its small size.

The sample from Massachusetts contains the smallest average errors. The largest average errors, other than Rhode Island's, are less than $\$ 1,000$. The graphs indicate 
that the samples from Oregon and the New England states are very similar. The differences in the magnitude of errors is evident when the size of the errors for California and comparable states are presented.

A second density stripe graph was prepared to compare the total average errors from the sample of returns from California with the samples containing the greatest average errors. The size of the average errors from these states approaches $\$ 11,000$. With the maximum on the scale set at $\$ 12,000$, it is evident that three of the states appear to have large total errors because each sample contains one extreme value.

The pattern of larger average errors is consistent for Oklahoma. The extreme values for New Mexico, Delaware and South Dakota cause these states to rank among the top five states on the bar charts in Appendix A. If the extreme values are ignored, the pattern of errors from these states is very similar to those in California's sample.

The bar charts, shown in Appendix A, display the rankings of the total values of cumulative changes in income, adjustments and deductions. The differences are expressed as absolute values to allow all of the errors to count, whether the error was in favor of the taxpayer or the IRS. All of the changes in exemptions for New Mexico, for example, now add to the totals. Expressing those 
changes in absolute values contributes to New Mexico's returns showing the highest changes in the 50 states.

While the bar graphs cannot be considered to represent any statistical significance, it is important to note that Oregon is among states with the lowest total changes while California ranks with che top 25 percent of the states in magnitude of changes upon TCMP examination.

\section{Cluster Analysis}

While the graphs show that there are differences among the states, it is difficult to conclude that those differences are due only to the regulation of commercial income tax preparers without further information. Cluster analysis is appropriate to detect groupings among the states because the number and size of the groups are not known in advance.

To begin the analysis, values were developed for each attribute of taxpayer compliance and IRS administrative activity. The goal is to identify groups of states with similar measures of taxpayer compliance. Reducing the variability among these attributes should facilitate testing differences in the error rates as a function of the state regulation of the tax preparer.

The index of similarity used to identify distances between the states is Euclidean distance. This is used because it is the most common and most familiar. It may be 
unsatisfactory for raw data because it is affected by differences in the scales of the variables (Everitt, 1980: 18). Because of this, the variables were standardized to preserve the relative distances between clusters.

Since the optimum number of clusters was unknown, initially a partitioning cluster analysis in systat called R-means procedure was used. The default setting for $\mathrm{K}$ means is two, which split the fifty states into two groups and placed Oregon and California in the same cluster. Successive runs, increasing the number of clusters each time, separated other states individually or into small clusters. The least number of clusters which placed Oregon and California individually with their own groups of states was twelve. The results are shown in Appendix $C$. The Oregon cluster contains Kansas, Kentucky, Nebraska, Virginia and wisconsin while California clusters with Arizona, Florida, Hawaii, North Dakota and New York. Tree or hierarchial clustering was also run on systat to verify the procedure as suggested by Wilkinson (1988: 388). Although the resulting hierarchical structure is useful in verifying the partitioning of the clusters, it also provides information about the relatedness of the clusters that is not available in the $\mathrm{K}$-means results. The hierarchical structure also identifies virginia and Wisconsin and Kansas and Nebraska as subsets of the larger cluster containing Oregon and Rentucky. Arizona ana 
California form a subset of the larger cluster containing North Dakota, Florida, Hawaii and New York. Both clustering procedures identify the members of these groups of states. Oregon clusters with states with good compliance, and California clusters with states where historically the compliance has not been as good.

The statistics for the clusters containing oregon and California and the summary of the statistics for all twelve clusters are shown in Appendix $C$. The distance statistics for each of the variables used to groun the states are also shown on box and whisker plots. A key identifying each of the twelve clusters is presented with the box and whisker plots. Wilkinson (1988: 434) developed the following diagram (Figure 1) to illustrate the information provided in the box and whisker plots. Approximately one-half of the

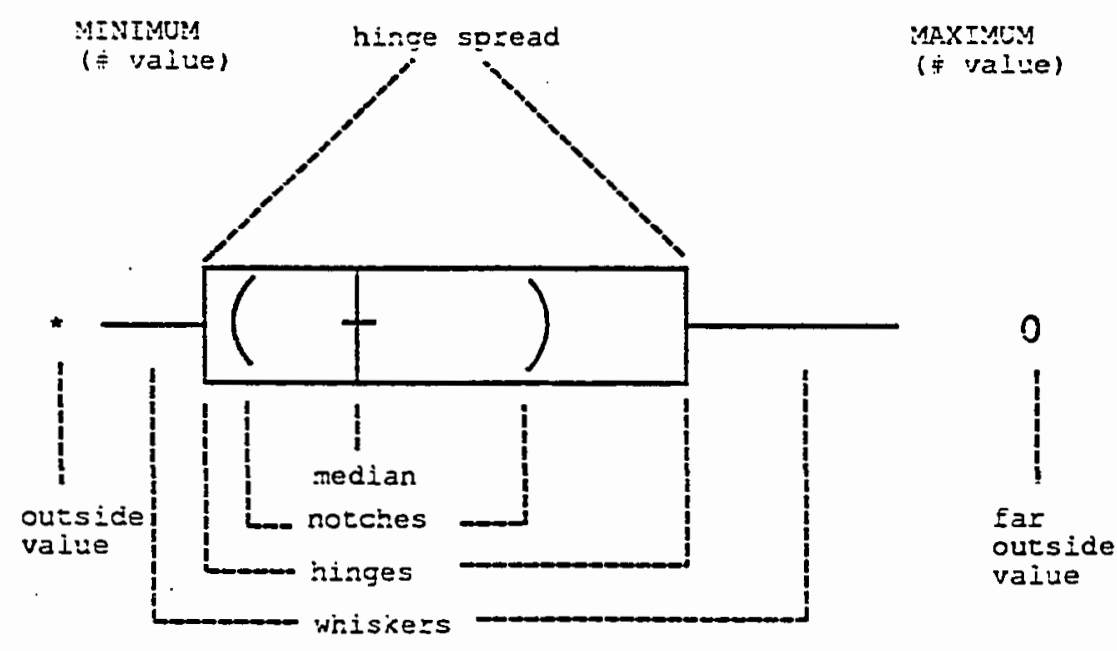

Figure 1. Diagram of information provided in a box plot. Source: Wilkinson, 1988: 388 . 
observations lie within the box. Of that portion, one-half of the observations lie between the median and one side of the box and one-half between the median and the other side of the box. The quartiles are approximate because the Systat procedure identifies and sets apart "outside" and "far outside" values beyond the box and whiskers. The two clustering procedures, described and interpreted above, complete the descriptive portion of the analysis. To better interpret the differences, nonparametric methods were used to determine if the differences among the states are significant.

\section{NONPARAMETRIC RESULTS AND INTERPRETATIONS}

For each hypothesis, descriptions of the significance of the differences began with a general comparison of Oregon to all nonregulated states. Next, Oregon was compared with the clustered states and with the Northwestern states. The presentation for California followed a similar format with minor differences. The results for California began with a general comparison to some of the nonregulated states, followed by a comparison with the clustered states and the Southwestern states. There are overlaps in the groupings for California. The states of Hawaii and Arizona which appear in both clustered and Southwestern groups are discussed only once. Finally, California and Oregon were compared for each of the hypotheses. 
Measurement Methodology

One of the primary purposes of this research is to adequately describe the data. This is the first opportunity to obtain information regarding the differences between returns prepared by commercial tax preparers in various states. Therefore, so as to minimize Type II errors, results will be reported at higher $\mathrm{p}$ values than are usually expected. The tables will list $p$ values as large as .2 to give the reader a more comprehensive description of the results.

The second reason for reporting the larger $p$ values is relative to the nonparametric methods used to test the data. The tests are more conservative than parametric methods and may not show differences if the reported levels are arbitrarily set at .10 or .05 .

Although results as large as .20 are reported in the tables, the significance level is set at .10 for discussion purposes in the following material. All tests are calculated as one-tail tests. The model for each test can be stated as:

Null Hypothesis

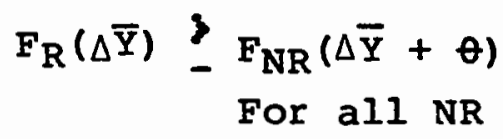

Alternate Hypothesis $F_{R}\left(\Delta \bar{Y} \& F_{N R}(\Delta \bar{Y}+\theta)\right.$ For some NR

Where $\bar{Y}$ is the difference

$R$ is a regulated state NR is a non-regulated state 
The Kolmogorov Smirnov test measures differences in the cumulative distributions. The sign and wilcoxon tests pair observations and measure differences relative to the medians of the samples.

\section{Hypothesis I}

Items chosen to test the integrity and competency of the commercial preparer are exemptions, contributions, tip income and medical expense deductions. These items were chosen by the Internal Revenue service in their studies of 1972 and 1973 to test the integrity and competence of commercial tax preparers. Summaries of the tests' results for Hypothesis I are given in Tables III through VII.

Oregon Compared with Nonregulated states. The results (Table III) from analyzing the sample of commercially prepared returns from unregulated states indicate that these returns contained larger errors. Analysis of the samples from Illinois, New Jersey, New York, Oklahoma and Texas all indicate consistent $p$ values less than . 10 . The tests were consistent in indicating significant differences between Oregon and these states. Adjusting the dollar values of differences to percentages of income changed the significance levels of the results on the samples from Florida, Hawaii and Maine. On other samples, such as those from Georgia, Indiana and Mississippi, this adjustment did not affect the results. Preliminary evaluation of the data indicated that the errors on returns 
TABLE III

NONREGULATED STATES: COMPARISON WITH OREGON
$P \leqslant .20$

Bypothesis I Integrity of Commercial preparers

\begin{tabular}{|c|c|c|c|c|c|c|}
\hline \multirow{2}{*}{$\begin{array}{c}\text { States } \\
\text { Compared } \\
\text { with } \\
\text { Oregon } \\
\end{array}$} & \multicolumn{2}{|c|}{ Sign Test } & \multicolumn{2}{|c|}{ Wilcoxon Test } & \multicolumn{2}{|c|}{ Kolmogorov Test } \\
\hline & $\begin{array}{l}\text { Dollar } \\
\text { Change }\end{array}$ & $\begin{array}{l}\text { Percent- } \\
\text { age of } \\
\text { Income }\end{array}$ & $\begin{array}{l}\text { Dollar } \\
\text { Change }\end{array}$ & $\begin{array}{l}\text { Percent- } \\
\text { age of } \\
\text { Income }\end{array}$ & $\begin{array}{l}\text { Dollar } \\
\text { Change }\end{array}$ & $\begin{array}{l}\text { Percent- } \\
\text { age of } \\
\text { Income }\end{array}$ \\
\hline \multirow{7}{*}{$\begin{array}{l}\text { Alaska } \\
\text { Alabaima } \\
\text { Arkansas } \\
\text { Arizona } \\
\text { Colorado } \\
\text { Connecticut } \\
\text { Delaware } \\
\text { Florida } \\
\text { Georgia } \\
\text { Hawaii } \\
\text { Iowa } \\
\text { Idaho } \\
\text { Ilinois } \\
\text { Indiana } \\
\text { Ransas } \\
\text { Rentucky } \\
\text { Louisiana } \\
\text { Massachusetts } \\
\text { Maryland } \\
\text { Maine } \\
\text { Michigan } \\
\text { Minnesota } \\
\text { Micsolri }\end{array}$} & .076 & .154 & .160 & .150 & $\begin{array}{l}.170 \\
.025\end{array}$ & .025 \\
\hline & .039 & $\begin{array}{r}.039 \\
.032\end{array}$ & .096 & $\begin{array}{l}.066 \\
: 110\end{array}$ & & \\
\hline & $\begin{array}{l}.154 \\
.095 \\
.132\end{array}$ & .076 & $\begin{array}{l}.069 \\
.070 \\
.031\end{array}$ & $\begin{array}{l}.046 \\
.075 \\
.068\end{array}$ & $\begin{array}{r}.190 \\
.160 \\
.042 \\
.190\end{array}$ & $\begin{array}{l}.055 \\
.165\end{array}$ \\
\hline & .012 & .012 & $\begin{array}{r}.055 \\
.124\end{array}$ & $\begin{array}{r}.065 \\
.130\end{array}$ & .055 & .055 \\
\hline & $: \frac{1}{1} 32$ & .200 & .1040 & $: 100$ & $\begin{array}{l}.930 \\
.100\end{array}$ & .067 \\
\hline & .014 & $\begin{array}{l}.190 \\
: 014 \\
.170\end{array}$ & $\begin{array}{l}.002 \\
.068\end{array}$ & .025 & .018 & .047 \\
\hline & & $\begin{array}{l}.135 \\
.047\end{array}$ & $: 042$ & .091 & .110 & \\
\hline $\begin{array}{l}\text { Mississippi } \\
\text { Montana }\end{array}$ & .040 & .040 & .011 & .014 & $: 041$ & .041 \\
\hline N. Carolina & .009 & .009 & .011 & .010 & .042 & .018 \\
\hline $\begin{array}{l}\text { N. Hampsnire } \\
\text { New Jersey } \\
\text { New }\end{array}$ & .047 & .110 & .005 & .077 & .0005 & .0015 \\
\hline $\begin{array}{l}\text { New Mexico } \\
\text { Nevada } \\
\text { New York }\end{array}$ & .200 & $\begin{array}{r}.155 \\
.012\end{array}$ & $: 077$ & $\begin{array}{l}: 1 \\
: 0685 \\
: 069\end{array}$ & - $1 \frac{110}{011}$ & $\begin{array}{l}.055 \\
.004\end{array}$ \\
\hline $\begin{array}{l}\text { Okio } \\
\text { Okiahoma } \\
\text { Pennsylvania }\end{array}$ & $\begin{array}{l}: 110 \\
: 009 \\
: 110\end{array}$ & $\begin{array}{l}: 110 \\
: 009 \\
: 100\end{array}$ & $\begin{array}{l}-144 \\
: 027 \\
: 130\end{array}$ & .031 & .018 & $\begin{array}{l}: 018 \\
.011\end{array}$ \\
\hline $\begin{array}{l}\text { Roode 1stana } \\
\text { S. Carolina } \\
\text { S. Dakota }\end{array}$ & .100 & $\begin{array}{r}.100 \\
.060\end{array}$ & .1300 & $\begin{array}{r}.180 \\
.034 \\
.027\end{array}$ & .160 & $\begin{array}{l}.087 \\
.081\end{array}$ \\
\hline Tenas & $: \frac{1}{3} \frac{1}{32}$ & $\div \frac{1}{3} 2$ & $: 052$ & $: \frac{1}{6} \frac{1}{62}$ & .100 & .100 \\
\hline $\begin{array}{l}\text { Utan } \\
\text { Virginia } \\
\text { Vermont } \\
\text { Washington } \\
\text { Wisconsin } \\
\text { W. Virginia } \\
\text { Wyoming }\end{array}$ & .140 & $\begin{array}{l}140 \\
.190\end{array}$ & .043 & .040 & & \\
\hline
\end{tabular}


from Delaware, North Dakota and Vermont are smaller, rather than larger, than those on the returns prepared in Oregon. Oregon Compared to Clustered states. The results (Table IV) indicate errors on returns from Kentucky were larger than those from oregon; the $\mathrm{p}$ values for the Kolmogorov-Smirnov and Wilcoxon test are .10 or less. The tests are less conclusive for returns from Kansas. Pairing the observations brought indications that the errors are larger but the results are not consistently significant. Larger error rates on the Nebraska sample are not indicated by the three tests. The sign test indicates errors are larger for Virginia and Wisconsin, but the results are not conclusive.

TABLE IV

CLUSTERED STATES: COMPARISON WITH OREGON Hypothesis I Integrity of Commercial Preparers

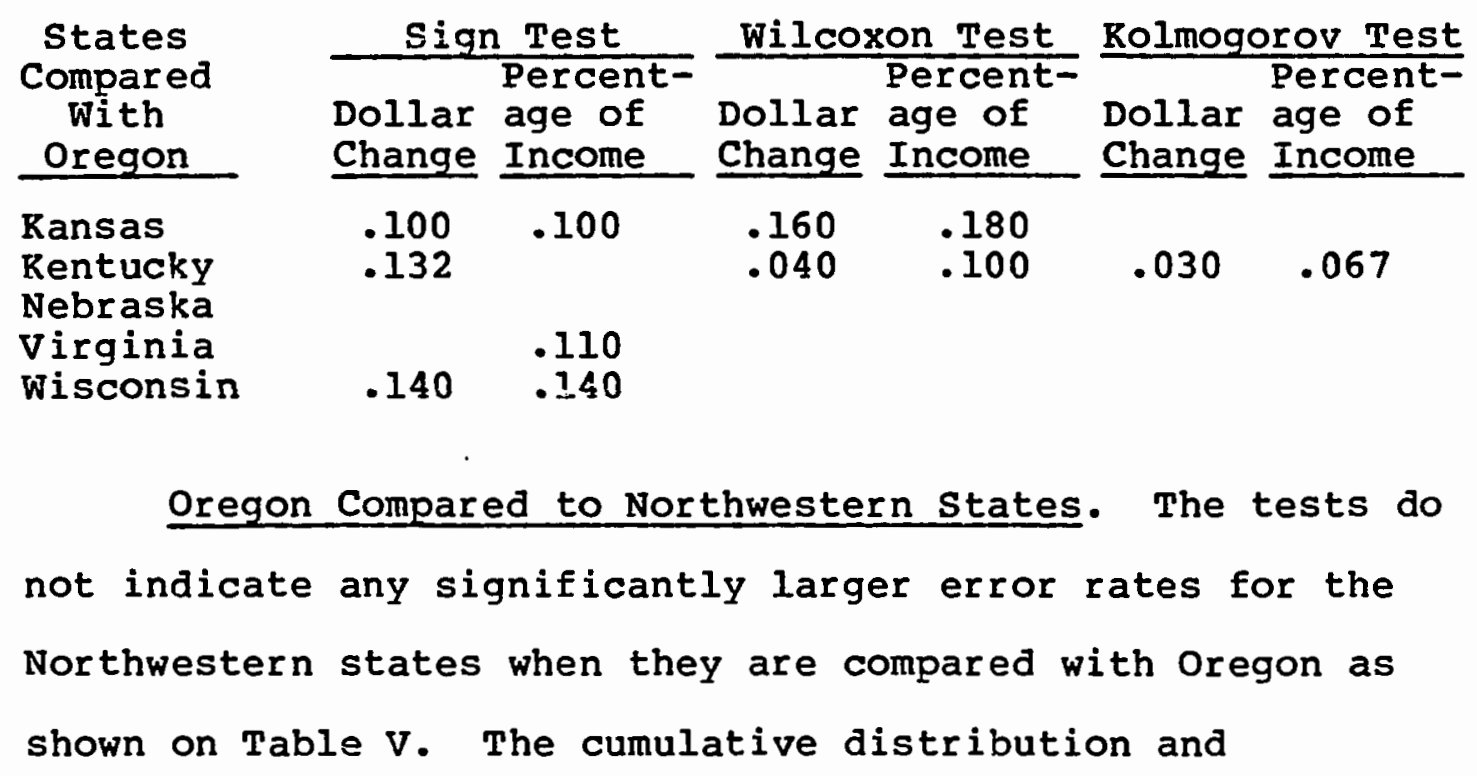


magnitude of errors are indicated to be larger for Alaska's returns measured as dollar values. When these values are adjusted to percentages of income, the tests do not inaicate differences.

TABLE V

NORTHWESTERN STATES: COMPARISON WITH OREGON

Hypothesis I Integrity of Commercial Preparers

\begin{tabular}{l} 
States \\
Compared \\
With \\
Oregon \\
\hline
\end{tabular}

Alaska

Idaho

Montana

Washington

Wyoming

\begin{tabular}{llll}
$\frac{\text { Sign Test }}{\text { Percent- }}$ & $\frac{\text { wilcoxon Test }}{\text { Percent- }}$ & $\frac{\text { Kolmogorov Test }}{\text { Percent- }}$ \\
Dollar age of & Dollar age of Dollar age of \\
Change Income & Change Income Change Income \\
\hline
\end{tabular}

.160

$$
.170
$$

\section{California Compared with Selected Nonregulated}

States. The results in Table VI show $\mathfrak{p}$ values of less than .20 for only three states. Preliminary evaluations indicated that California's returns contained larger errors

TABLE VI

SELECTED NONREGULATED STATES: COMPARISON WITH CALIFORNIA $P \& .20$

Hypothesis I Integrity of Commercial Preparers

\section{States \\ Compared \\ with}

California

Fawaii

New Jersey

New Mexico

Nevada

New York

$\frac{\text { Sign Test }}{\text { Percent- }} \frac{\text { Wilcoxon Tst }}{\text { Percent- }} \frac{\text { Kolmogorov Test }}{\text { Percent- }}$
Dollar age of Dollar age of Dollar age of
Change Income

$.042 \quad .087$

.190 
than the majority of the nonregulated states. Over half of the nonregulated states had error rates or amounts substantially smaller than California. The most substantial differences are indicated for returns from Delaware, Idaho, Montana, Nebraska, Wisconsin and Wyoming. California Compared to Clustered states. Testing for differences in the cumulative distributions of the samples indicates that the errors on the returns from Hawaii are larger than those from California as shown on Table VII. The initial evaluation of the data indicated that the errors on returns from all four of the other clustered states were actually smaller than the errors on the returns from California.

TABLE VII

CLUSTERED STATES: COMPARISON WITH CALIFORNIA Hypothesis I Integrity of Commercial Preparers

\begin{tabular}{clll} 
States & Sign Test & Wilcoxon Test & Rolmogorov Test \\
Compared & \multicolumn{1}{c}{ Percent- } & Percent- & Percent- \\
With & Dollar age of & Dollar age of & Dollar age of \\
California & Change Income & Change Income & Change Income \\
\hline
\end{tabular}
Arizona Florida Hawai i $.042 \quad .087$

N. Dakota

New York

\section{California Compared to the Southwestern States.}

Testing for differences in the cumulative distributions indicates (Table VIII) that errors on Hawaii's and Nevada's returns are larger than those from California. The 
preliminary analysis indicated that the errors on returns from Arizona, Colorado and Utah are smaller than those on returns from California.

TABLE VIII

SOUTHWESTERN STATES: COMPARISON WITH CALIFORNIA

Hypothesis I Integrity of Commercial Preparers

States
Compared
with

California

$\frac{\text { Sign Test }}{\text { Percent- }}$

Change Income

$\frac{\text { wilcoxon Test }}{\text { Percent- }}$

Change Income $\frac{\text { Kolmogorov Test }}{\text { Percent- }}$

Dollar age of Change Income

Arizona

Colorado

Hawai i

New Mexico

Nevada

$.042 \quad .087$

Utah

.190

Hypothesis II

Commercial income tax preparers in Oregon were subject to continuing education requirements. Tax law changes in 1977 and 1978 affected the treatment of capital gains, individual retirement accounts, residential energy credits and earned income credits on the 1979 tax returns. If the requirement to complete tax-related continuing education courses was effective, commercial preparers in oregon should have been more competent in the new items on the 1979 returns. Commercial preparers in California were not subject to continuing edication requirements, therefore, California will be considered with the nonregulated states 
in evaluating the tests for Hypothesis II. Summaries for Hypothesis II are given in Tables IX through XI.

Oregon Compared to Nonregulated States. The pattern of differences continues with the tests on the new items from the samples as shown in Table IX. Many of the unregulated states have larger errors on the new items. Errors on returns from Florida, Louisiana, Maryland and New York are significantly larger with $\mathrm{p}$ values of less than .05 indicated from all of the nonparametric tests. The tests indicate larger errors on the returns from Alabama, California, Missouri, New Jersey and Pennsylvania. The results are significant with $\mathrm{p}$ values ranging between .05 and .10. Adjusting the dollar values of the changes to percentages of income results in very few changes in the significance of the differences on these tests. The states of Alabama and Mississippi have lower average incomes and the $p$ values change when the differencus are restated to percentages of income. Prelimin-ary evaluations of the data indicated that the errors on the returns from Hawaii and South Dakota were smaller than those from Oregon. Oregon Compared to Clustered states. Larger error rates (Table $X$ ) are not indicated by the tests of the sample of returns from Ransas. Reference to the preliminary evaluation of the data indicates that the size of errors on the returns from Ransas are smaller, rather than larger, than the errors on Oregon's returns. 
TABLE IX

NONREGULATED STATES: COMPARISON WITH OREGON $\mathrm{P} \nsubseteq .20$

Hypothesis II Continuing Education

\begin{tabular}{|c|c|c|c|c|c|c|}
\hline \multirow{2}{*}{$\begin{array}{c}\text { states } \\
\text { Compared } \\
\text { with } \\
\text { Oregon } \\
\end{array}$} & \multicolumn{2}{|c|}{ Sign Test } & \multicolumn{2}{|c|}{ Wilcoxon Test } & \multicolumn{2}{|c|}{ Kolmogorov Test } \\
\hline & $\begin{array}{l}\text { Dollar } \\
\text { Change }\end{array}$ & $\begin{array}{l}\text { Percent- } \\
\text { age of } \\
\text { Income }\end{array}$ & $\begin{array}{l}\text { Dollar } \\
\text { Change }\end{array}$ & $\begin{array}{l}\text { Percent- } \\
\text { age of } \\
\text { Income }\end{array}$ & $\begin{array}{l}\text { Dollar } \\
\text { Change }\end{array}$ & $\begin{array}{l}\text { Percent- } \\
\text { age of } \\
\text { Income }\end{array}$ \\
\hline \multirow{16}{*}{$\begin{array}{l}\text { Alaska } \\
\text { Alabama } \\
\text { Arkansas } \\
\text { Arizona } \\
\text { CoIorado } \\
\text { Connecticut } \\
\text { Delaware } \\
\text { Florida } \\
\text { Georgia } \\
\text { Hawai } \\
\text { Iowa } \\
\text { Idaho } \\
\text { Illinois } \\
\text { Indiana } \\
\text { Kansas } \\
\text { Rentucky } \\
\text { Louisiana } \\
\text { Massachusett } \\
\text { Maryland } \\
\text { Maine } \\
\text { Michigan } \\
\text { Minnesota } \\
\text { Missouri } \\
\text { Mississippi } \\
\text { Montana }\end{array}$} & \multirow{2}{*}{.084} & $\begin{array}{l}.032 \\
.151\end{array}$ & \multirow[t]{2}{*}{.160} & \multirow[t]{2}{*}{.130} & .041 & $\begin{array}{l}.041 \\
.160\end{array}$ \\
\hline & & .050 & & & .018 & .018 \\
\hline & $\begin{array}{l}.025 \\
.084\end{array}$ & .025 & .031 & $\begin{array}{l}.031 \\
.160\end{array}$ & $\begin{array}{l}.041 \\
.086\end{array}$ & .041 \\
\hline & $\begin{array}{l}.084 \\
.180\end{array}$ & $\begin{array}{l}.084 \\
.032\end{array}$ & .20 & .100 & .041 & $\begin{array}{l}.086 \\
.041\end{array}$ \\
\hline & $\begin{array}{r}.050 \\
\text { s. }\end{array}$ & $\begin{array}{l}.050 \\
.001\end{array}$ & .043 & $\begin{array}{l}.032 \\
.039\end{array}$ & .067 & $\begin{array}{l}.030 \\
.041\end{array}$ \\
\hline & .0005 & .0005 & .005 & .005 & .041 & .041 \\
\hline & .032 & 0.032 & & & .041 & .041 \\
\hline & .040 & $: 040$ & .180 & .170 & $\begin{array}{l}.007 \\
.067\end{array}$ & $\begin{array}{l}.007 \\
.067\end{array}$ \\
\hline & .084 & .084 & .160 & & $\begin{array}{l}.050 \\
.135\end{array}$ & $\begin{array}{l}.050 \\
.067\end{array}$ \\
\hline & .050 & .050 & .092 & .100 & .004 & .004 \\
\hline & $\begin{array}{l}.060 \\
.0035 \\
.0205\end{array}$ & $\begin{array}{l}.060 \\
.0035 \\
.0205 \\
.140\end{array}$ & $\begin{array}{l}110 \\
: 050 \\
.190\end{array}$ & $\begin{array}{l}.110 \\
: 046 \\
: 190\end{array}$ & $\begin{array}{l}.0005 \\
.065\end{array}$ & $\begin{array}{l}0005 \\
.018\end{array}$ \\
\hline & .040 & $: 013$ & .155 & .137 & .0005 & .0005 \\
\hline & .120 & .120 & .110 & .092 & & \\
\hline & $\begin{array}{l}.060 \\
.025\end{array}$ & .130 & .180 & .190 & .086 & .086 \\
\hline & .010 & .010 & .086 & .100 & .018 & .018 \\
\hline & .0325 & .0325 & .078 & .091 & $\begin{array}{l}.086 \\
.041\end{array}$ & $\begin{array}{l}.086 \\
.041 \\
.170\end{array}$ \\
\hline
\end{tabular}


The errors on new items on the 1979 returns are indicated to be significantly greater for Rentucky and Virginia for all three tests. Testing for differences in the cumulative distribution indicates that the errors are significantly greater on the returns from Nebraska and wisconsin than those on the returns from Oregon.

\section{TABLE $X$}

CLUSTERED STATES: COMPARISON WITH OREGON

Hypothesis II Continuing Education

\begin{tabular}{|c|c|c|c|c|c|c|}
\hline \multirow{3}{*}{$\begin{array}{c}\text { States } \\
\text { Compared } \\
\text { with } \\
\text { Oregon }\end{array}$} & \multicolumn{2}{|c|}{ Sign Test } & \multicolumn{2}{|c|}{ Wilcoxon Test } & \multicolumn{2}{|c|}{ Kolmogorov Test } \\
\hline & & Percent - & & Percent- & & Percent- \\
\hline & $\begin{array}{l}\text { Dollar } \\
\text { Change }\end{array}$ & $\begin{array}{l}\text { age of } \\
\text { Income }\end{array}$ & $\begin{array}{l}\text { Dollar } \\
\text { Change }\end{array}$ & $\begin{array}{l}\text { age of } \\
\text { Income }\end{array}$ & $\begin{array}{l}\text { Dollar } \\
\text { Change }\end{array}$ & $\begin{array}{l}\text { age of } \\
\text { Income }\end{array}$ \\
\hline
\end{tabular}

Kansas

Kentucky

Nebraska

Virginia

$$
\begin{array}{ll}
.050 & .050 \\
.010 & .010
\end{array}
$$$$
.043
$$$$
.032
$$$$
.067
$$$$
.030
$$$$
.086
$$

.100

.018

.041

.030

050

.018

.041

\section{Oregon Compared to the Northwestern States. The}

tests do not indicate differences (Table XI) among the

TABLE XI

NORTHWESTERN STATES: COMPARISON WITH OREGON

Hypothesis II Continuing Education

\begin{tabular}{l} 
States \\
Compared \\
With \\
Oregon \\
\hline
\end{tabular}

Alaska

Idaho

Montana

Washington

wyoming

\begin{tabular}{llll}
$\frac{\text { Sign Test }}{\text { Percent- }}$ & $\frac{\text { Wilcoxon Test }}{\text { Percent- }}$ & $\frac{\text { Rolmogorov Test }}{\text { Percent- }}$ \\
Dollar age of Dollar age of Dollar age of \\
Change Income & Change Income & Change Income \\
\hline
\end{tabular}

$$
.086 \quad .086
$$


Northwestern states other than an indication that the cumulative distribution of Washington's errors is different.

\section{Hypothesis III}

Items which have continually caused problems for middle-income taxpayers were chosen from the tax returns. These items were included in AICPA seminars in 1979 because the procedure was complex or the recordkeeping was a problem for taxpayers. Results for Hypothesis III are given in Tables XII through XVII,

Oregon Compared to Nonregulated States. Although the results (Table XII) from these tests are not as consistent, errors are shown to be larger on the returns from Florida, Georgia, New Mexico, Pennsylvania and Tennessee. Since the Wilcoxon test is more sensitive to the magnitude of the errors, many significant differences are indicated by this test. Restating the dollar changes to percentages of income affects the $\underline{\mathrm{q}}$ values for Missouri, North Carolina and Nevada. Preliminary evaluations showed that returns from Hawaii, South Carolina and Utah had smaller errors than those from Oregon. 
TABLE XII

NONREGULATED STATES: COMPARISON WITH OREGON

$$
\mathrm{P} \nsubseteq .20
$$

Hypothesis III Troublesome Items

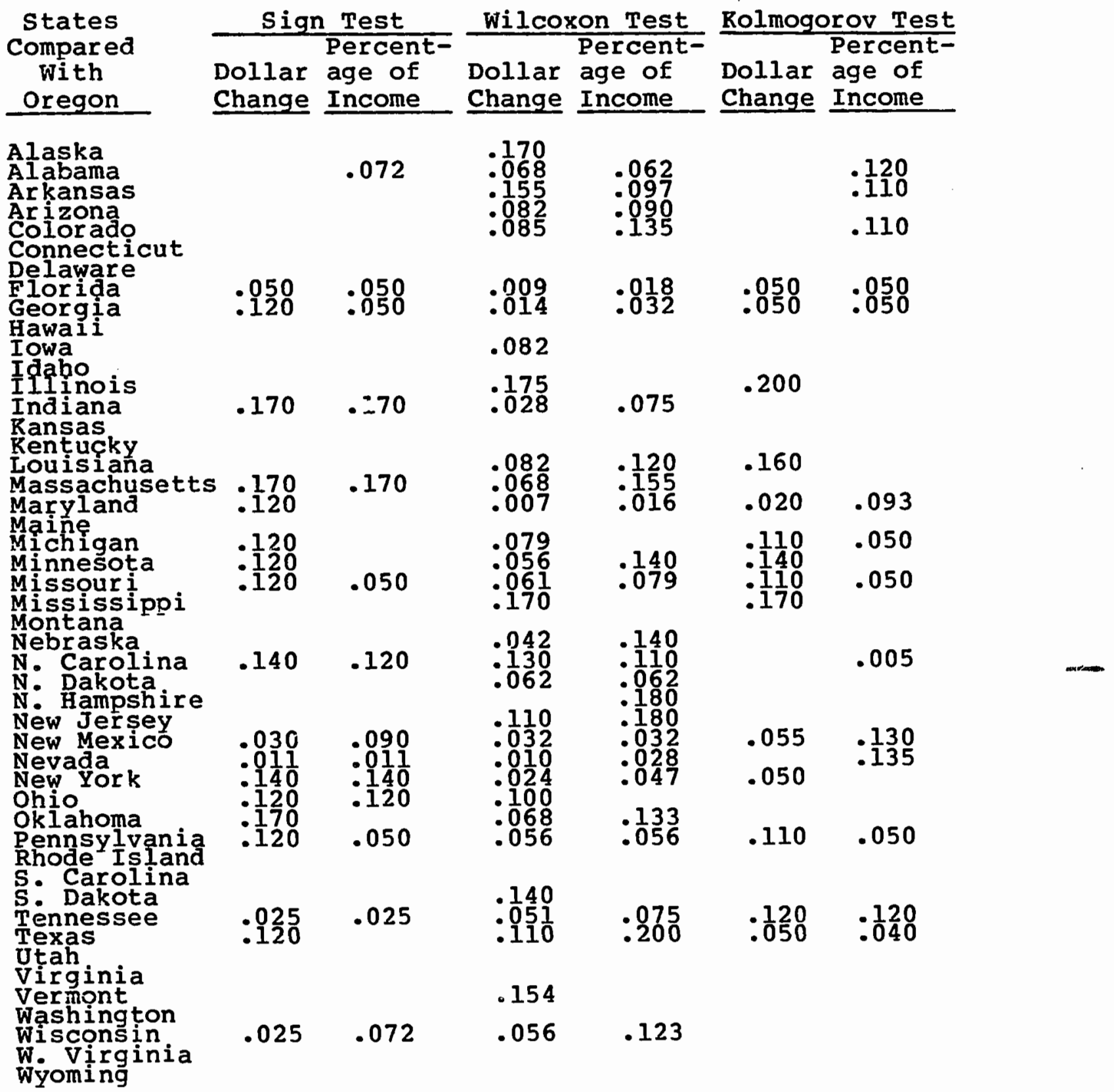


Oregon Compared to Clustered States. The results (Table XIII) of the tests do not indicate that the errors on the returns from Kansas, Kentucky or Virginia are larger than those from Oregon. Preliminary evaluations of the data indicated that the errors on the returns from Ransas were actually smaller.

TABLE XIII

CLUSTERED STATES: COMPARISON WITH OREGON Hypothes is III Troublesome Items

\begin{tabular}{|c|c|c|c|c|c|}
\hline \multirow{3}{*}{$\begin{array}{c}\text { States } \\
\text { Compared } \\
\text { with } \\
\text { Oreqon }\end{array}$} & \multicolumn{2}{|c|}{ Sign Test } & \multicolumn{2}{|c|}{ Wilcoxon Test } & Rolmogorov Test \\
\hline & & Percent- & & Percent- & Percent \\
\hline & $\begin{array}{l}\text { Dollar } \\
\text { Change }\end{array}$ & $\begin{array}{l}\text { age of } \\
\text { Income }\end{array}$ & $\begin{array}{l}\text { Dollar } \\
\text { Change }\end{array}$ & $\begin{array}{l}\text { age of } \\
\text { Income }\end{array}$ & $\begin{array}{l}\text { Dollar } \\
\text { Change }\end{array}$ \\
\hline
\end{tabular}

Kansas

Kentucky

Nebraska

Virginia

wisconsin

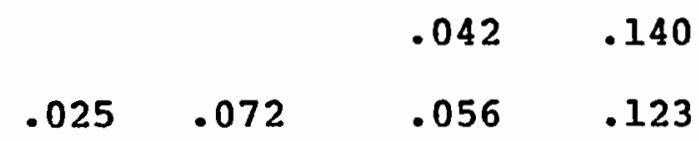

The tests for differences in the cumulative distributions do not indicate differences between Oregon and Nebraska or Wisconsin. The sign test indicates that the errors are larger on the returns from wisconsin. The wilcoxon test indicates that the magnitude of the errors is larger on the returns from both Nebraska and wisconsin and significant at the .05 level for dollar value. The results are not significant when the amounts are restated as percentages of income. 
Oregon Compared to the Northwestern States. The tests (Table XIV) do not indicate differences in the error rates or amounts among the Northwestern states other than an indication that the dollar values of the errors may be larger on returns from Alaska.

TABLE XIV

NORTHWESTERN STATES: COMPARISON WITH OREGON Hypothesis III Troublesome Items

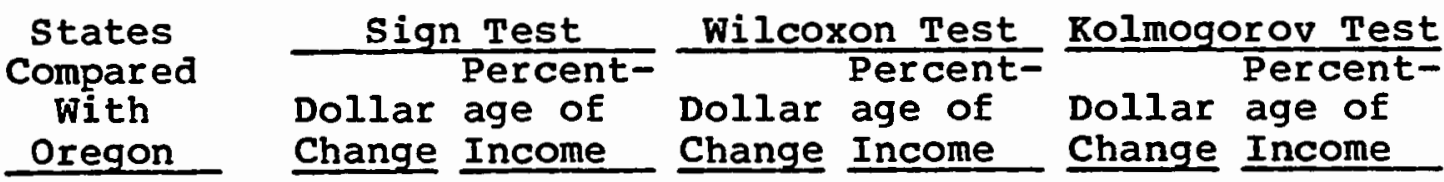

Alaska

Idaho .170

Montana

Washington

Wyoming

California Compared to Nonregulated states.

California is more comparable to the nonregulated states on the complex items, including farming and proprietorship income as shown on Table XV. The returns from New Mexico have larger errors and the results become significant when the dollar values are restated as percentages of income. The results from the other states are mixed. Preliminary evaluations of the data indicated that the errors on the returns from Connecticut, Ransas, Ohio and South Carolina are substantially smaller than those from California. 
TABLE XV

SELECTED NONREGULATED STATES: COMPARISON WITH CALIFORNIA $P \leq \cdot 20$

Hypothesis III Troublesome Items

\begin{tabular}{|c|c|c|c|c|c|}
\hline \multirow{2}{*}{$\begin{array}{c}\text { States } \\
\text { Compared } \\
\text { with } \\
\text { Califronia }\end{array}$} & \multicolumn{2}{|c|}{ Sign Test } & \multicolumn{2}{|c|}{ Wilcoxon Test } & Kolmogorov Test \\
\hline & $\begin{array}{l}\text { Dollar } \\
\text { Change }\end{array}$ & $\begin{array}{l}\text { Percent- } \\
\text { age of } \\
\text { Income }\end{array}$ & $\begin{array}{l}\text { Dollar } \\
\text { Change }\end{array}$ & $\begin{array}{l}\text { Percent- } \\
\text { age of } \\
\text { Income }\end{array}$ & $\begin{array}{l}\text { Percent- } \\
\text { Dollar age of } \\
\text { Change Income }\end{array}$ \\
\hline
\end{tabular}

Color ado

Connecticut

Delaware

Florida

Georgia

Hawai i

Maryland

N. Dakota

N. Hampshire

$\begin{array}{ll}.132 & .124 \\ & .073\end{array}$

New Jersey

New Mexico

Nevada

New York

Tennessee

Texas

$\begin{array}{lllll} & & & .135 & .135 \\ & & .140 & .170 & \\ & & & & \\ & .090 \quad & .032 & & .056\end{array}$

.135

California Compared to Clustered states. The tests

(Table XVI) indicate that the errors on returns from

Florida and North Dakota are larger than those from

TABLE XVI

$$
\begin{aligned}
& \text { CLUSTERED STATES: COMPARISON WITH CALIFORNIA } \\
& P \leq .20
\end{aligned}
$$

Hypothesis III Troublesome Items

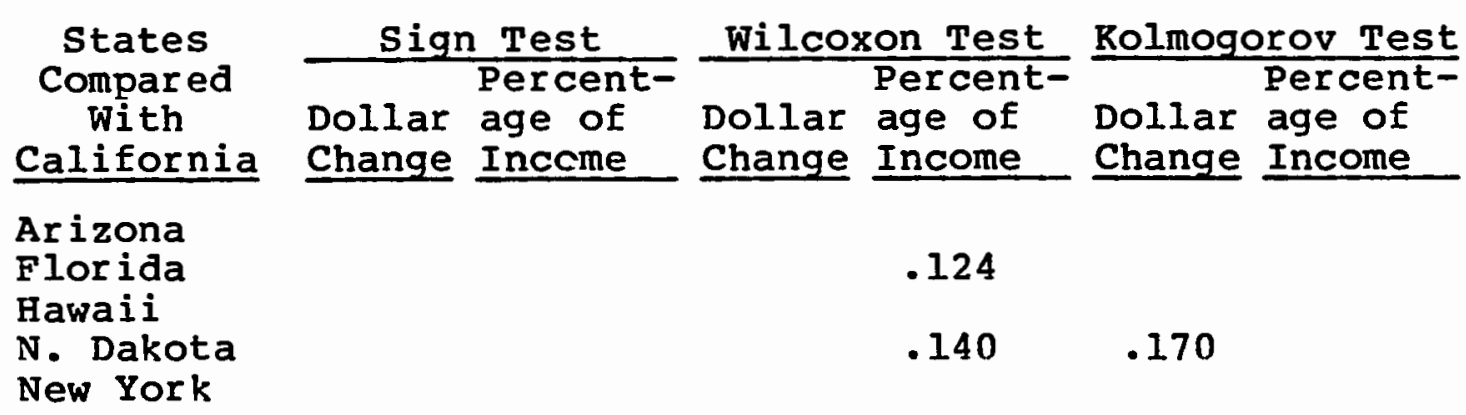


California. The preliminary evaluation of the data indicated that the errors on returns from Hawaii are smalier. California Compared to the Southwestern states. When the Southwestern states are compared with California (Table XVII) the tests indicate that the returns from New Mexico have larger errors. The initial evaluation of the data indicated that the errors on the returns from Utah are substantially smaller than those from California.

TABLE XVII

SOUTHWESTERN STATES: COMPARISON WITH CALIFORNIA $P \underline{\mathbf{i}} \cdot \mathbf{2 0}$

Hypothesis III Troublesome Items

\begin{tabular}{clll} 
States & Sign Test & Wilcoxon Test & Rolmogorov Test \\
\cline { 2 - 2 } & Wercent- & Percent- & Percent- \\
With & Dollar age of Dollar age of & Dollar age of \\
California & Change Income & Change Income & Change Income \\
\hline
\end{tabular}

Arizona

Colorado

Hawa i i

$\begin{array}{lllll}\text { New Mexico } & .090 & .200 & .032 & .056\end{array}$

Nevada

Utah

\section{Hypothesis IV}

In the preceding tests, individual items from the tax returns were chosen to test integrity, effectiveness of continuing education and competence on the commercial preparer on complex items. This hypothesis is designed to test the differences on the return caused by the cumulative 
effect of errors on totals for income, adjustments and deductions. Summaries of tesc results are presented in Tables XVIII through XXII.

Oregon Compared With Nonregulated States. When the total errors on the returns from Oregon and the nonregulated states are compared (Table XVIII), Alabama, Minnesota, Oklahoma and Texas have larger errors with $p$ values of .02 or less. The errors on returns from Florida, Georgia, Mississippi and New Mexico are larger and the results are sensitive to the restatement of the dollar values to percentages of income. Preliminary evaluations of the data indicate that the differences on the returns from Massachusetts, Rhode Island and New Hampshire are smaller. Reference to the bar graphs in Appendix A confirms that these states have smaller total errors. Oregon Compared With Clustered States. The tests do not indicate that the errors are larger on the returns from Ransas or Nebraska as shown on Table XIX. All of the tests indicate that the errors on tax returns for Kentucky are significantly larger. The sign test indicates that the errors are larger on the returns from virginia and wisconsin. 
TABLE XVIII

NONREGULATED STATES: COMPARISON WITH OREGON $P \leq .20$

Hypothesis IV Totals

\begin{tabular}{|c|c|c|c|c|c|c|}
\hline \multirow{2}{*}{$\begin{array}{c}\text { states } \\
\text { Compared } \\
\text { with } \\
\text { Oregon } \\
\end{array}$} & \multicolumn{2}{|c|}{ Sign Test } & \multicolumn{2}{|c|}{ Wilcoxon Test } & \multicolumn{2}{|c|}{ Kolmogorov Test } \\
\hline & $\begin{array}{l}\text { Dollar } \\
\text { Change }\end{array}$ & $\begin{array}{l}\text { Percent- } \\
\text { age of } \\
\text { Income }\end{array}$ & $\begin{array}{l}\text { Dollar } \\
\text { Change }\end{array}$ & $\begin{array}{l}\text { Percent- } \\
\text { age of } \\
\text { Income }\end{array}$ & $\begin{array}{l}\text { Dollar } \\
\text { Change }\end{array}$ & $\begin{array}{l}\text { Percent- } \\
\text { age of } \\
\text { Income }\end{array}$ \\
\hline $\begin{array}{l}\text { Alaska } \\
\text { Alabama } \\
\text { Arkansas } \\
\text { Arizona } \\
\text { Colorado } \\
\text { Connecticut }\end{array}$ & $\begin{array}{l}.020 \\
.073\end{array}$ & .020 & $\begin{array}{r}.110 \\
.005 \\
.050 \\
.110\end{array}$ & $\begin{array}{r}.003 \\
.050 \\
.080 \\
.180\end{array}$ & $\begin{array}{l}.093 \\
.002 \\
.093\end{array}$ & $\begin{array}{l}.0005 \\
.093\end{array}$ \\
\hline $\begin{array}{l}\text { Delaware } \\
\text { Florida } \\
\text { Georgia } \\
\text { Hawait }\end{array}$ & $\begin{array}{l}.073 \\
.020\end{array}$ & .020 & .010 & $\begin{array}{l}.004 \\
.010\end{array}$ & .033 & .033 \\
\hline $\begin{array}{l}\text { Hawali } \\
\text { Iowa } \\
\text { Idaho } \\
\text { IIIinois } \\
\text { Indiana }\end{array}$ & & .073 & $\begin{array}{l}.190 \\
.068 \\
.068 \\
.021\end{array}$ & $\begin{array}{l}.079 \\
.050 \\
.0075\end{array}$ & .093 & .093 \\
\hline $\begin{array}{l}\text { Kansas } \\
\text { Rentuckyy } \\
\text { Louisiana }\end{array}$ & .200 & .073 & .017 & .005 & .033 & .033 \\
\hline $\begin{array}{l}\text { Massachusetts } \\
\text { Maryland } \\
\text { Maine }\end{array}$ & S. .073 & .073 & .036 & $\begin{array}{r}.050 \\
.140\end{array}$ & & \\
\hline $\begin{array}{l}\text { Michigan } \\
\text { Minnesota } \\
\text { Missouri }\end{array}$ & $\begin{array}{r}.020 \\
.190\end{array}$ & .003 & .012 & $\begin{array}{l}.120 \\
.006 \\
.130\end{array}$ & $\begin{array}{r}.033 \\
.009 \\
.093\end{array}$ & .033 \\
\hline Mississippi & .073 & .002 & .042 & .021 & .093 & .093 \\
\hline $\begin{array}{l}\text { N. Carolina } \\
\text { N. Dakota }\end{array}$ & .073 & .073 & .110 & $\begin{array}{r}.155 \\
.059\end{array}$ & & \\
\hline $\begin{array}{l}\text { New Jer sey } \\
\text { New Mexico } \\
\text { Nevada } \\
\text { New York }\end{array}$ & $\begin{array}{l}.073 \\
.020 \\
.073\end{array}$ & $\begin{array}{l}.073 \\
.020 \\
.020\end{array}$ & $\begin{array}{l}.021 \\
.030 \\
.030 \\
.030\end{array}$ & $\begin{array}{l}: 124 \\
: 030 \\
: 014 \\
.025 \\
.021\end{array}$ & $\begin{array}{l}.009 \\
.093 \\
.093 \\
.002\end{array}$ & $\begin{array}{r}.033 \\
.033 \\
.093 \\
.033\end{array}$ \\
\hline $\begin{array}{l}\text { Oklo } \\
\text { Pennsylvania }\end{array}$ & $\begin{array}{l}.020 \\
.073\end{array}$ & .003 & $\begin{array}{l}.0025 \\
.012\end{array}$ & .0022 & $\begin{array}{l}.009 \\
.009\end{array}$ & $\begin{array}{l}.002 \\
.033\end{array}$ \\
\hline $\begin{array}{l}\text { Sode Carolina } \\
\text { S. Dakota }\end{array}$ & & .020 & $\begin{array}{l}.060 \\
.065\end{array}$ & .010 & $\begin{array}{l}.093 \\
.093\end{array}$ & $\begin{array}{l}.093 \\
.032\end{array}$ \\
\hline Tennessee & .073 & .0220 & .025 & .025 & .093 & .0005 \\
\hline $\begin{array}{l}\text { Virginia } \\
\text { vermont } \\
\text { washington }\end{array}$ & .200 & & & .193 & & \\
\hline $\begin{array}{l}\text { wisconsin } \\
\text { w. virginia } \\
\text { wyoming }\end{array}$ & .020 & $\begin{array}{l}.200 \\
.073\end{array}$ & .012 & .036 & .033 & \\
\hline
\end{tabular}


TABLE XIX

$$
\begin{gathered}
\text { CLUSTERED STATES: COMPARISON WITH OREGON } \\
\text { P } \leq .20
\end{gathered}
$$

Hypothesis IV Totals

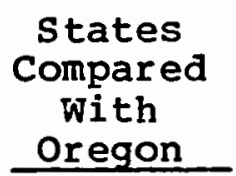

$\begin{array}{ll}\frac{\text { Sign Test }}{\text { Percent }} & \frac{\text { Wilcoxon Test }}{\text { Percent- }} \\ \text { Dollar age of } & \text { Dollar age of } \\ \text { Change Income } & \text { Change Income }\end{array}$
$\frac{\text { Rolmogorov Test }}{\text { Percent- }}$ Dollar age of Oregon Change Income Change Income

Kansas Kentucky Nebraska Virginia wisconsin

$\begin{array}{ll}.200 & .073 \\ .200 & .200\end{array}$

.017

.005

$.033 \quad .033$

Oregon Compared with Northwestern States. The tests indicate that the errors on totals of income, adjustments and deductions are larger on the returns from Idaho as shown on Table XX. The Wilcoxon test indicates that the differences are significant. The tests indicate that the dollar values of errors on the returns from Alaska are larger, but not significant. When the errors are restated

TABLE XX

NORTHWESTERN STATES: COMPARISON WITH OREGON
P $\$ .20$ Eypothesis IV Totals

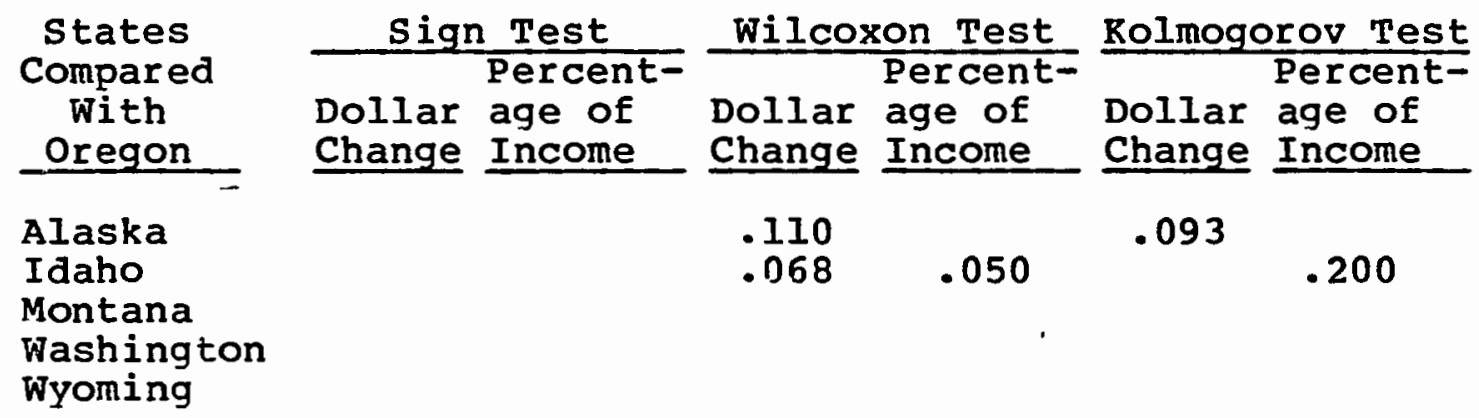


to percentages of income, the differences are no longer evident. The tests do not indicate larger errors for returns from Montana, Washington and Wyoming.

California Compared with the Nonregulated states.

The tests (Table XXI) indicate that Alabama, Oklahoma and Texas have larger errors than California. These results are consistent with the ranking of the states using the totals of all of the errors. The results of the tests are similar to the information obtained from the density stripe graph in Appendix $c$. Other than single extreme values from New Mexico, South Dakota and Delaware, only the sample from Oklahoma contains consistently larger values than those from California.

TABLE XXI

SELECTED NONREGULATED STATES: COMPARISON WITH CALIFORNIA

$$
\mathrm{P}: 20
$$

Hypothesis IV Totals

\begin{tabular}{|c|c|c|c|c|c|c|}
\hline \multirow{3}{*}{$\begin{array}{c}\text { States } \\
\text { Compared } \\
\text { with } \\
\text { California }\end{array}$} & \multicolumn{2}{|c|}{ Sign Test } & \multicolumn{2}{|c|}{ Wilcoxon Test } & \multicolumn{2}{|c|}{ Kolmogorov Test } \\
\hline & & Percent- & & Percent & & Percent- \\
\hline & $\begin{array}{l}\text { Dollar } \\
\text { Change }\end{array}$ & $\begin{array}{l}\text { age of } \\
\text { Income }\end{array}$ & $\begin{array}{l}\text { Dollar } \\
\text { Change }\end{array}$ & $\begin{array}{l}\text { age of } \\
\text { Income }\end{array}$ & $\begin{array}{l}\text { Dollar } \\
\text { Change }\end{array}$ & $\begin{array}{l}\text { age of } \\
\text { Income }\end{array}$ \\
\hline
\end{tabular}

\section{Alabama}

N. Hampshire

New Jersey

New Mexico

Nevada

New York

Ohio

Oklahoma

Texas

Utah
.120

.136

$.174 \quad .068$

.093

.093 
California Compared with the Clustered States. A separate table is not presented for these results since the nonparametric tests do not indicate differences in the errors among any of the clustered states. The initial evaluation of the data indicated that the errors on the returns from Arizona, Hawaii and North Dakota are smaller than California's errors.

California Compared with Southwestern states. The tests, shown on Table XXII, indicate that New Mexico is the only state among the Southwestern states that has larger errors than California. Ranking the states on the bar graphs indicated that the errors on returns from New Mexico were the largest among all of the states. The initial evaluation of the data indicated that the errors were smaller on returns from Colorado and Utah.

TABLE XXII

SOUTHWESTERN STATES: COMPARISON WITH CALIFORNIA $P \leq .20$

Hypothesis IV Totals

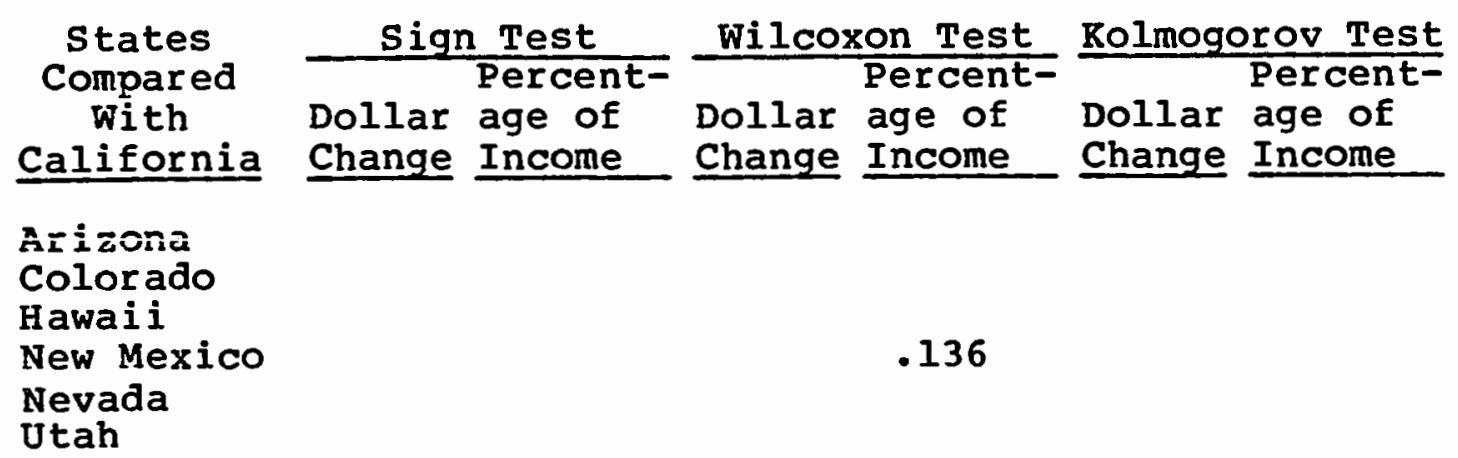


Hypothesis V

The final hypothesis is designed to evaluate the differences between levels of occupational regulation. California registers commercial tax preparers while Oregon has a strict licensing system. The data is evaluated for each of the preceding four hypotheses in Table XXIII.

TABLE XXIII

COMPARISON OF CALIFORNIA WITH OREGON P $\$ .20$

Hypothesis $V$ Differences in Regulation Levels

\begin{tabular}{|c|c|c|c|c|c|c|}
\hline \multirow[b]{3}{*}{ voothesis } & \multicolumn{2}{|c|}{ Sign Test } & \multicolumn{2}{|c|}{ Wilcoxon Test } & \multicolumn{2}{|c|}{ Kolmogorov Test } \\
\hline & & Percent- & & Percent- & & Percent- \\
\hline & $\begin{array}{l}\text { Dollar } \\
\text { Change }\end{array}$ & $\begin{array}{l}\text { age of } \\
\text { Income }\end{array}$ & $\begin{array}{l}\text { Dollar } \\
\text { Change }\end{array}$ & $\begin{array}{l}\text { age of } \\
\text { Income }\end{array}$ & $\begin{array}{l}\text { Dollar } \\
\text { Change }\end{array}$ & $\begin{array}{l}\text { age of } \\
\text { Income }\end{array}$ \\
\hline
\end{tabular}

$\begin{array}{lllllll}\text { Integrity } & .001 & .001 & .004 & .005 & .011 & .011 \\ \text { Edication } & .004 & .004 & .053 & .050 & .001 & .001 \\ \text { Complexity } & .004 & .016 & .003 & .010 & .120 & \\ \text { Totals } & .003 & .000 & .0015 & .001 & .002 & .009\end{array}$

Integrity of the Commercial preparer. All of the nonparametric tests indicate that the errors on Oregon's returns are smaller with $p$ values of .01 or less.

Effects of Continuing Education. The nonparametric tests indicate that the errors in oregon are smaller, primarily the $\mathrm{g}$ values are .05 . Continuing education was required in Oregon during 1979 for all commercial preparers.

Complexity of Items. The Kolmogorov-Smirnov test indicates that the cumulative distribution of the errors in 
Oregon is smaller. The sign test and the wilcoxon tests indicate that the number and magnitude of errors are smaller for Oregon with $\mathrm{p}$ values of .05 . Total Errors. All of the tests indicate that the errors for Oregon are smaller with $p$ values of .05 or less. 


\section{CHAPTER VI}

\section{INTERPRETATIONS AND CONCLUSIONS}

The research hypothesis is that state regulation of commercial income tax preparers would improve the quality of income tax return preparation. For purposes of the analysis, the level of quality is the size of errors made on returns filed during the 1979 tax season. The 1979 Taxpayer Compliance Measurement Program (TCMP) files provide the data for analysis. The analysis is divided into two parts: the first being a descriptive analysis. The second part of the analysis used nonparametric statistical methods to determine if there are significant differences among returns prepared by commercial preparers in nonregulated and regulated states.

\section{SUMMARY}

\section{Descriptive Measures}

The first objective of the analysis is to describe the data because the 1979 TCMP files have not been previously available for academic research. The 1969 TCMP files were released to academics in 1981 and research has been completed and published by clotfelter (1983) and witte 
and Woodbury (1985). Both of these studies are used to provide background information for this analysis of the 1979 TCMP data.

Model tax returns were prepared for each major type of tax preparer and for each state pertinent to the research question. The differences between the reported amounts and the corrected amounts from the returns appear to be highest among professionally prepared returns and lowest among returns prepared by individual taxpayers. Returns completed by commercial preparers vary in accuracy between the other two categories. When the errors are restated as percentages of income, the pattern remains. Errors, as percentages of income, are highest among professional preparers. The largest errors appear on returns prepared by commercial preparers in New Mexico, Oklahoma, South Dakota, Texas and Alabama. The smallest errors appear on commercially prepared returns from Massachusetts, Rhode Island, New Hampshire and Connecticut.

A number of charts and graphs were prepared to analyze the differences among the commercially prepared returns. The final procedure in the descriptive section was to cluster the states based on taxpayer compliance and Internal Revenue Service (IRS) administrative activities. Based on these attributes, Oregon clusters with midwestern 
states, Rentucky and Virginia, while California clusters with sun-belt states and New York.

Analysis Using Nonparametric Statistic:3

Differences are evident from the descriptive analysis. The next step is to determine if the differences are significant. The sample size is 20,883 partitioned by four types of commercial preparers in 50 states. The 1979 TCMP data are aggregated as means by the preparer types by districts. Measures of dispersion such as range or variance are not available. Therefore, for testing, each mean was treated as a single observation. Because of the resulting small sample sizes, nonparametric methods were used to test the hypotheses.

Items were chosen from the returns to test integrity of the preparers, continuing education requirements, competency on complex items and total differences on income, adjustments and deductions. To summarize the results, the comparisons of Oregon and the nonregulated states are presented first. The hypotheses are combined and presented to compare California and the nonregulated states. Finally. differences in levels of regulation between Oregon and California are tested.

Hypothesis I. Items were chosen from the returns which the IRS had used during 1972 to test the integrity of commercial taxpayers. When Oregon is compared to all of 
the states on these items, the errors on the returns are substantially higher among the nonregulated states. Clustering the states reduces the differences. The states in the Northwest appear to be more similar to oregon than the clustered states. The results indicate that Oregon has larger errors than Delaware, North Dakota and Vermont. The three tests produced very similar results, although the wilcoxon test appears to be slightly more sensitive.

Hypothesis II. Items which affected middle-income taxpayers were chosen from the 1977 and 1978 tax legislation (Aronson, Greene, Fisher and Co., 1979). These new items on the 1979 returns were chosen to test the effectiveness of Oregon's continuing education requirements for commercial tax preparers. Again, most of the nonregulated states have larger errors than Oregon. Returns from Hawaii, South Dakota and Kansas have smaller errors than Oregon. The wilcoxon test is the least sensitive. The clustered states are more similar, the errors are larger than Oregon, but there are not as many significant differences. The differences between Oregon and the other states in the Northwest are not significant.

Hypothesis III. Items were chosen from the returns which caused problems for taxpayers and accounted for a large percentage of changes on many tax returns. The wilcoxon test appears to be the most sensitive to the differences. Most of the states again have larger errors than 
Oregon, but there are not as many significant results. Wisconsin has larger errors among the clustered states but there are no significant differences among the Northwestern states. Hawaii, South Carolina and Utah have smaller errors than Oregon.

Hypothesis IV. The totals for income, adjustments and deductions were chosen from the returns to test for the cumulative differences in the total amounts from the returns. As the totals are accumulated, the differences between Oregon and the nonregulated states are significant. Massachusetts, Rhode Island and New Hampshire have smaller errors. Again, Rentucky has larger errors among the clustered states and Idaho has the larger errors among the Northwestern states. Using just the totals necessitated a smaller sample from the returns making nonparametric tests even more appropriate. The three tests produce similar results on these smaller samples.

Hypotheses I, III and IV for California. The research hypotheses are similar to test the differences between California and the nonregulated states. California's preparers were not required to complete continuing education courses so Hypothesis II was omitted. The results from testing all of the remaining hypotheses are not significant so it is logical to combine the results. For each hypothesis, California's errors are substantially larger than a majority of the nonregulated 
states. A few states have larger errors than California, but those differences are not significant. Only New Mexico's errors are significantly larger than California's on the complex items, which contributes to the largest total errors on returns from New Mexico when the totals from the returns are considered.

Hypothesis $\mathrm{V}$. The final tests were designed to compare the levels of regulation. The state of California has the least restrictive form of regulation while Oregon maintains a strict licensing program for commercial tax preparers. All of the tests detected significant differences between the error rates on returns prepared in Oregon and California. California's errors are significantly higher in all of the areas as measured by all three of the tests.

\section{CONCLUSIONS}

Does state regulation of commercial income tax preparers affect the quality of income tax return preparation? Evaluation of the model returns prepared for the various states indicates that the error rates for Oregon are among the lowest in the United states. Graphing the results also indicates that Oregon's returns have smaller errors. The nonparametric statistical tests lead to the same conclusion.

The initial description of the analysis leads to the conclusion that the error rates on amounts in Oregon are 
significantly less than those measured in nonregulated staces. If the research had concluded at this point, the results would have been misleading. It seemed necessary to consider prior research, taxpayer attributes and regional differences among the states, and these refinements of the research question lead to less conclusive results.

In evaluating Oregon with the clustered states and among the states of the Northwest, she results of the statistical analysis are less clear. The differences are less evident. Often no differences are indicated by the tests. The descriptive measures continue to indicate that the errors in Oregon are smaller, but these measures do not offer any statistical significance. When the totals for all of the items are considered for Hypothesis IV, the New England states have smaller errors than those on returns from Oregon.

In conclusion, when Oregon is compared to all of the states in the United States, the tests indicate that the null hypotheses can be rejected. When the analysis is put in a historical perspective and Oregon is clustered with the states of similar tax administrative attributes, the results are less clear. The descriptive statistics still indicate that Oregon's errors are smaller but the nonparametric tests do not produce significant results.

The results are much clearer for the comparisons of California and the nonregulated states. The tests do not 
indicate that regulation in California lowers the amount or rate of errors on any of the groups of items chosen to test the hypotheses. When California is clustered with states of similar taxpayer attributes, the state clusters with states of lesser compliance. This may be due to the IRS administrative activities which are higher in all of these states, presumably to improve compliance. The nonparametric and descriptive statistics lead to similar conclusions. Although New Mexico's errors are larger than California's, the remaining states either have smaller errors or the nonparametric tests do not detect substantial differences. None of the results obtained from testing the samples of the returns from California would indicate that registration or bonding of California's commercial preparers is effective in lowering the error rate below comparable states.

The final hypothesis was designed to evaluate the effectiveness of less stringent occupational regulation. As with the first evaluation concerning Oregon and other states, the statistical tests provide clear results. The error rates on returns from California are significantly nigher than those on returns from Oregon. The null hypothesis can be rejected. A qualification seems necesssary here since it is apparent from the remainder of the research that California is not comparable to oregon without considering other factors. California and oregon 
not only have different state regulation of commercial tax preparers, cluster analysis and historical information indicate that the taxpaying public is different. The statistical tests give clear signals, but there may be other factors involved in the differences on the returns from Oregon and California.

\section{LIMITATIONS}

Research based on data collected for other purposes than the one used for the particular analysis has a number of limitations. The TCMP data is in an aggregate form by district and does not contain measures of dispersion for those districts. Therefore, the type of statistical analysis that could be used to test for the differences was limited.

When the preliminary descriptions of the data were evaluated, it became apparent that the level of aggregation of the data presented a second problem. The effect of negative errors cancelled the effect of positive errors on the returns. That is, errors in favor of the taxpayer were cancelled by errors made in favor of the Treasury. As a result, the totals of the ercors for the districts had to be understated but the amount of the understatement cannot be estimated from the data available.

There are three other weaknesses in the TCMP data mentioned by clotfelter (1983) that are relevant but of 
lesser importance to this study. First, the information compiled from each individual tax return includes the reported amounts from the original return and the amounts the auditor deemed "correct" following the audit. Because these amounts only represent the IRS's opinion on taxes due, these "corrected" amounts may be appealed and thus are not necessarily "true." The second weakness is that it is difficult for auditors to detect many forms of unreported income. Third, the TCMP data fails to reflect information on taxpayers who did not file tax returns (Clotfelter, 1983: 366).

Finally, there is confusion among taxpayers as to the different types of tax preparers. The taxpayers were asked to identify the type of preparer who completed their return. These responses, classifying the tax preparer, were not verified by the TCMP examiner. Any inaccuracy in the responses of the taxpayers would be reflected in the results obtained from the analysis.

Regardless of the limitations, the TCMP data are the only source of information about the actual quality of returns prepared by commercial income tax preparers.

SUGGESTIONS FOR FURTHER RESEARCH

The TCMP data offers a treasure of information for analysis of a large sample of the tax returns filed in 1979. This data will soon be available for general 
academic research. The TCMP data from 1969 was released with the information aggregated at the three digit zip code level. If this is possible for the 1979 TCMP data, some of the problems encountered in this research will be mitigated. Specifically, measures of dispersion can be calculated for each district. In addition, the magnitude of the wFoblem of negative and positive errors may be subject to estimation. Most important, the learning process involved in accessing the data for this project can be carried over and used to facilitate research on the many issues involved in the complete data base from the 1979 TCMP cycle.

The 1979 TCMP data provided for this research were sorted by district by tax return preparer. When the 1979 TCMP data is made generally available, other copies of the print tapes should facilitate research in related areas. For example, the data will be sorted by IRS district by income level. It is evident from the decriptive analysis in this research that there are differences in tax compliance among income levels. There will be an opportunity, with the added information, to investigate the effect of levels of income on tax compliance. A sort by occupation code will also be available, adding to the opportunities for investigation.

of particular interest to researchers investigating the incidence of tax preparer penalties will be data sorted by IRS district by fraud or negligence penalties. If tax 
preparer code designations are also available with this data, questions about penalties relative to the type of tax preparer can be addressed.

Subsequent samples taken by the IRS as a part of the TCMP examinations have not included questions regarding the type of preparer involved in return preparation. Other important questions can be addressed by using the data from the 1982 TCMP cycle but the issue or regulation of commercial income tax preparers cannot be directly addressed unless the IRS can be convinced to add such questions to their questionnaires.

Longitudinal studies should be possible which would assess the effectiveress of IRS administrative activities. Tax legislation has addressed the compliance of taxpayers on a number of the items tested in this study. Further research is necessary to determine if tax administration or legislation is improving compliance on those items. Unfortunately, only a limited number of research papers, using the TCMP data, has been published due to restricted access to the information. The TCMP data provide an exciting, unique opportunity for research. It is important to expand the access to the data and to encourage academic research from a wider variety of disciplines. 
REFERENCES

Legal References

Allgeyer v. Louisiana, 165 U.S. 578, 589 (1897).

Barsky v. Board of Regents, 347 U.S. 442, 472 (1954), Justice Douglas (dissenting).

Burns Baking Co. v. Bryan, 264 U.S. 504, 513 (1924), Justice But $\overline{\text { Ier. }}$ 
General References

American Institute of Certified Public Accountants. Individual Income Tax Returns Workshop Course Materials, 1979, pp. 1-1 to 6-13.

Anderberg, Michael R. Cluster Analysis for Applications. New York: Academic Press, Inc., 1971.

Aronson, Green, Fisher and Co., Chartered. "Memorandum: Revenue Act of 1978 and Other Major Tax Legislation," The National Public Accountant, 24, 1979, pp. 16-23.

Ayres, Francis L., Jackson, Betty R., and Hite, Peggy S. "The Economic Benefits of Regulation: Evidence from Professional Tax Preparers," The Accounting Review, 64 (2), 1989, pp. 300-312.

Benjamin, Marc A. "Definition of a Preparer--Who Is He?" The Tax Adviser, 10, 1979, pp. 516, 528-529.

Bentler, Peter M. (Editor). Data Analysis Strategies and Designs for Substance Abuse Research. Washington, D.C.: U.S. Superintendent of Documents, 1976.

Blackmon, John A. "To Iicense or Register Them?" The Georgia CPA, 17, 1976, pp. 7-14.

Blalock, Hubert M., Jr. Social Statistics. New York: McGraw-Hill, 1979.

Boyle, James P. "IRS's View of the Commercial Tax Preparer Industry," The National Public Accountant, 18, 1973, pp. 16-18.

California Assembly Iabor, Employment, and Consumer Affairs Committee Hearings on Changes on Registration Process for Tax Preparers, 1977.

California Department of Consumer Affairs. Report of Hearing and Recommendations, March $197 \overline{8}$.

Cathcart, James A., and Graff, Gil. "Occupational Licensing: Factoring It Out," Pacific Law Journal, 9, 1978, pp. 147-163.

Chandler, Bettye R. "What Accreditation Means in an Unlicensed State," The National Public Accountant, 30,1985 , pp. 14, 48. 
Clotfelter, Charles T. "Tax Evasion and Tax Rates: An Analysis of Individual Returns," The Review of Economics and statistics, $65,198 \overline{3}$, pp. 363- $\overline{373}$.

Collins, Julie $\mathrm{H}$. and Milliron, Valerie C. "A Conceptual Model and Text of Taxpayer Noncompliance," Working Paper No. 86-43. Final research report submitted to the Arthur Young Foundation, July 1988.

Council of State Governments, The. Sidney Spector, Director of Research. Occupational Licensing Legislation in the states. Chicago: The council of state Governments, 1952 .

Davis, Earl F. "Regulation of Tax Return Preparers-Observations Based on an Empirical Study," Taxes, 53, 1975, pp. 161-180.

Dorsey, stuart. "The Occupational Licensing Queue," The

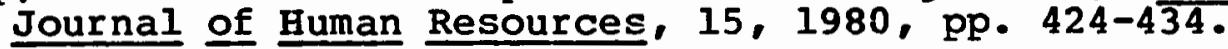

Editorial, "Paper Empire?" Forbes, 106, 1970, pp. 19-20.

Elliott, Clifford, and Smith, Vincent H. "Occupational Iicensing: An Empirical Approach," University of Michigan Business Review, 30, 1578, pp. 20-24.

Everitt, Brian. Cluster Analysis. New York: Halsted Press, 1980 .

Fellmeth, Robert C. "A Theory of Regulation: A Platform for State Regulatory Reform," California Regulatory Law Reporter, 5, 1985, pp. 3-20.

Friedman, Milton. Capitalism and Freedom. Chicago: The University of Chicago press, 1962.

Gadarowski, James J. "Regulation of Tax Preparers--Boon or Bane?" Taxes, 55, 1977, pp. 532-541.

Gellhorn, Walter. Individual Freedom and Governmental Restraints. Baton Rouge: Louisiana State University Press, 1956 .

Gellhorn, Walter. "Occupational Licensing--A Nationwide Dilemma," The Journal of Accountancy, 109, 1960, pp. 39-45.

General Accounting Office, Comptroller General. "No Apparent Need to Regulate Commercial Preparers of 
Income Tax Returns," Report to the Joint Committee on Internal Revenue Taxation Congress of the United States, 1975 .

Gibbons, Jean Dickinson. Non-Parametric Methods for Quantitative Analysis. New York: Holt, Rinehart and Winston, 1976 .

Gray, Robert L. "Non-Professional Tax and Accounting Services," The New York Certified Public Accountant,

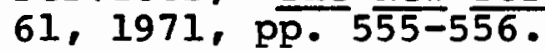

Griswold, Erwin M. "We Can Stop the Lawyer-Accountant Conflict Over Tax Practice Now: Four Recommendations," The Journal of Taxation, 2, 1955, pp. 130-137.

Groves, Harold M. "Income-Tax Administration," National Tax Journal, 12, 1959, pp. 37-53.

Hanigsberg, Oscar, and Keiser, Laurence. "Preparer Penalties: A New Look," The CPA Journal, 50, 1980, pp. 19-22, 48-54.

Hanlon, John F. "IRS Return Preparer Program: The Second Season," The National Public Accountant, 18, 1973, pp. 8-11.

Harless, Raymond R. "Taxpayer Assistance and the Tax Practitioner," The National Public Accountant, 18, 1973, pp. 12-19.

Hartgraves, Al, and Beard, Larry H. "Accounting: An Occupation or a Legal Designation?" The National Public Accountant, 27, 1982, pp. 12- $\overline{14}$.

Henderson, Bernard J. "Professional Regulation: Maybe Less is Best," The National Public Accountant, 28, 1983, pp. 16-17.

Hinshaw, Robert D. "State Constitutional Law--Effective Limitation of Occupational Licensing," Wake Forest Law Review, 13, 1977, pp. 507-521.

Hite, Peggy A. "The Effect of Peer Reporting Behavior on Taxpayer Compliance," The Journal of the American Taxation Association, $9,1988, \mathrm{pp} . \frac{17}{4-64}$.

Holle, Larry A. "Why Regulate Tax Return Preparers?" Nebraska Law Review, 53, 1974, pp. 94-113. 
Horvitz, Jerome S., and Whittington, Oliver Ray III. "Responsibilities in Tax Practice," The CPA Journal, 68 , 1978, pp. 26-31.

Hoskins, W. Lee. "Professional Certification: An Idea in Search of a Problem," Business Economics, 21, 1986, pp. 15-20.

Internal Revenue Service. 1981 Annual Report. Washington, DC: U.S. Government Printing Off $\overline{1 C e, ~} 1981$.

- Statistics of Income--1979, Individual Income Tax Returns. Washington, DC: U.s. Government Printing Office, 1982 .

- Taxpayer Compliance Measurement Program Handbook. Washington, DC: U.S. Government Printing Office, 1984 .

- Prentice Hall Complete Internal Revenue Code of 1954. Englewood Cliffs, N.J.: Prentice Hall, Inc., 1985.

Ramerow, Martin I. "Return Preparer Problems Since the Tax Reform Act of 1976," 39th Annual N.Y.U. Institute of Federal Taxation, 37-3-37-29.

Kaplan, Marshal, Gans, Sheldon P., and Kahn, Howard M. Study of Commercial Tax Preparation in California, 1976. (Report to the California Department of Consumer Affairs.

Kleiner, Morris M., Gay, Robert S., and Greene, Karen. "Barriers to Labor Migration: The Case of Occupational Licensing," Industrial Relations, 21 , 1982, pp. 383-391.

Legislative Research. Staff Sunset Review, state Board of Tax Service Examiners, Salem, Oregon, 1982.

Leland, Hayne E. "Quacks, Lemons, and Licensing: A Theory of Minimum Quality Standards," Journal of Political Economy, 87, 1979, pp. 1328-1346.

Lore, Martin M. "TCMP: The Service's Long-Range System for Measuring Taxpayer Compliance," The Journal of Taxation, 24,1966 , pp. 44-45.

Lore, Martin M., and Goldfein, Laurence. "When Preparer Penalties are Referred to the Service's Director of Practice," The Journal of Taxation, 57, 1982, pp. 240-241. 
Lowe, Herman J. Co-keynote address presented at th AICPANASBA National Conference, 1986.

Mason, Robert, and Lowry, Helen M. An Estimate of Income Tax Evasion in Oregon. Corvalis: Oregon State University survey Research Center, 1981.

Maurizi, Alex. "Occupational Licensing and the Public Interest," Journal of Political Economy, 82, 1974, pp. 399-413.

Miller, Jack. "More on Licensing Tax Return Preparers," The National Public Accountant, 17, 1972, pp. 14-18.

Milliron, Valerie C. and Toy, Daniel R. "Tax Compliance: An Investigation of Key Features," The Journal of American Taxation Association, 9, 1988, pp. 84-104.

Mills, Robert H. "Views on Education and Experience Requirements," Journal of Accountancy, 160, 1985, pp. 106-112.

Misiewicz, Kevin M. "Ethical Guidelines for Tax Practitioners," The CPA Journal, 51, 1981, pp. 42-50.

Monagan, John S. "The Dimension and Specifics of Governmental Regulation of the Tax Return Preparation Industry," The National Public Accountant, 18, 1973, pp. 8-11.

Mosteller, Frederick, and Rourke, Robert E. Sturdy Statistics: Nonparametric and Order statistics. Reading, Mass.: Addison-Wesley Publishing Co., 1973.

Myers, Max. "More on Regulation of Tax Return Preparers," Taxation for Accountants, 8, 1972, pp. 292-293.

- "IRS Does Not Favor Iicensing of Tax Return Preparers," Taxation for Accountants, 9, 1972, pp. 127-128.

Muzondo, Timothy R., and Pazderka, Bohumir. "Occupational Iicensing and Professional Incomes in Canada," Canadian Journal of Economics, 13, 1980, pp. 659-663.

National Association of state Boards of Accountancy (NASBA). Digest of State Accountancy Laws and State Board Requlations 1979. Englewood Cliffs, N.J: Prentice-Hall, 1979 .

Nicholas, P.R. "There Ought to be a Law," The National Public Accountant, 17, 1972, p. 4 . 
Olson, Wallace E. "How Should a Profession be Disciplined?" The Journal of Accountancy, 145, 1978, pp. 59-66.

Paul, Chris W. "Competition in the Medical Profession: An Application of the Economic Theory of Regulation," Southern Economic Journal, 48, 1982, 559-569.

- "Physician Licensure Legislation and the Quality of Medical Care," Atlantic Economic Journal, 12, 1984, pp. $18-30$.

Peltzman, Sam. "Toward a More General Theory of Regulation," Journal of Law and Economics, 19, 1976, pp. 211-240.

Pennell, John S., and Stevens, Robert S. "The Professional as a Tax Return Preparer: From the Perspective of the Accountant and the Lawyer," Taxes, 1978, pp. 726-727.

Pertschuk, Michael. "Licensing Professionals? It Perpetuates Elite Monopoly!" An address before the American Enterprise Institute Occupational Licensure Conference, 1979.

Pratt, Leila J. "Occupational Licensing and Interstate Mobility," Business Economics, 15, 1980, pp. 78-80.

Rassuli, Ali. "The Economic Impact of Occupational Licensure on Audiologists." Unpublished dissertation, The University of Nebraska, 1982.

Rosen. Irving. "Tax Return Preparer--Qualified or Quack," The National Public Accountant, 18, 1973, pp. 22-23.

Sager, William H. "1971--a Year of Increased Emphasis on Professional Responsibility," The National Public Accountant, 16, 1971, pp. 22-27.

- "Why License the Non-Certified Accountant?" The National Public Accountant, 30,1985, pp. 8, 44.

Shaked, Avner, and Sutton, John. "The Self Regulating Profession," Review of Economic Studies, 152, 1981, pp. 217-234.

Sheffield, Susie E., and Pollard, william B. "Tax Preparer Penalties," The CPA Journal, 55, 1985, pp. 34-40.

Shimberg, Benjamin, Esser, Barbara F., and Kruger, Daniel H. Occupational Licensing: Practices and Policies. Washington, DC: Public Affairs Press, 1982 . 
Shimberg, Benjamin. "Occupational Licensing: Help or Hindrance?" Occupational Outlook Quarterly, 17, 1973, pp. 32-34.

Simonetti, Gilbert Jr. "Regulation of Tax Return Preparers--It's on the Way," The Tax Adviser, 1972, pp. 345-350.

Slemrod, Joel, and Sorum, Nikki. "The Compliance cost of the U.S. Individual Income Tax System," National Tax Journal, 37, 1984, pp. 461-474.

Spector, Sidney. Occupational Licensing Legislation in the States. Chicago, IL: The Council of State Governments, 1952 .

Stolar, Rathleen Sowle. "Occupational Licensing: An Antitrust Analysis," Missouri Law Review, 41, 1976, pp. 66-79.

Tanner, Marcia. "The View from the Marketplace and the Great Accreditation Debate," Outlook, 53, 1985, pp. $15-19,47-51$.

Taylor, Hermon Christopher. "CPE--Impossible Burden or Essential Benefit?" Accountancy, 91, 1980, pp. 99-100.

Tinker, Anthony. "Accounting Regulation Theory," Journal of Accounting and Public Policy, 3, 1984, pp. 55-74.

U.S. Congress Committee on Government Operations, U.S. Taxpayer Assistance Services. Income Tax Return Preparation--IRS and the Commercial Return Preparer. Washington, DC: U.S. Government printing Office, 1973.

Wilkinson, Leland. Sygraph. Evanston, Ill.: Systat, Inc., 1988.

Williams, William E. "Current Developments on the Tax Scene Affecting Professional Preparers," The National Public Accountant, 23, 1978, pp. 8-13.

Wilson, Oliver H., and Smith, William J. "Access to Tax Records for Statistical Purposes," Review of Public Data Use, 12, 1984, pp. 295-305.

witschey, Robert E. "CPAs and Noncertified Practitioners," The Journal of Accountancy, 110, 1960, pp. 63-71. 
Witte, Ann D., and Woodbury, Diane F. "The Effect of Tax Laws and Tax Administration on Tax Compliance: The Case of the U.S. Individual Income Tax," National Tax Journal, 39, 1985, pp. 1-13.

Yankelovich, Skelly and White, Inc. Taxpayer Attitudes Study, Final Report to the Department of Treasury. Washington, DC: U.S. Government Printing Office, 1984 .

Young, S. David. "Accounting Licensure, Quality, and the 'Cadillac Effect,'" Journal of Accounting \& Public policy, 5, 1986, pp. 5-19. 
APPENDIX A

BAR CHARTS 


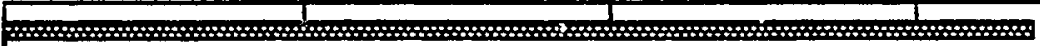

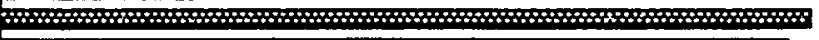
1.

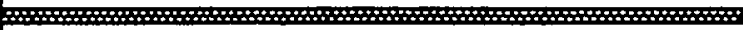

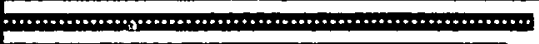

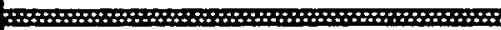

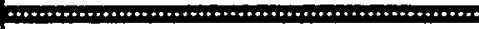
W $\quad$ W $\quad$ W

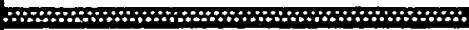
2.1.

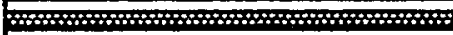

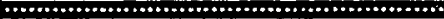
W $\quad$

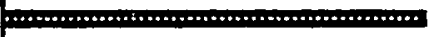
W

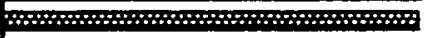
10.

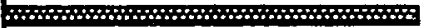

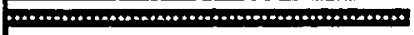
$\quad \quad \quad \quad \quad \quad \quad 2$

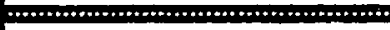

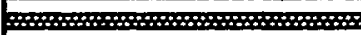

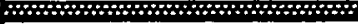

21 W

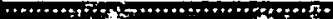
-

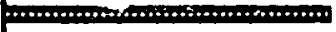
…

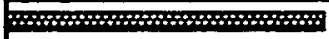

2.1.

$\ldots$

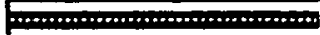

…………

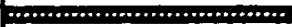

.

W

2

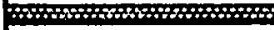

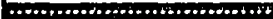

W. W. W

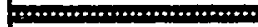

W1.

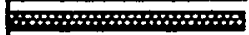

.

$\ldots$

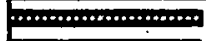

............

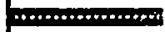

a

0 5000 10000

15000

\section{Total Dollar Changes}

Figure 2. Taxpayer Compliance Measurement Program (TCMP) examination sample data total dollar errors by state. 


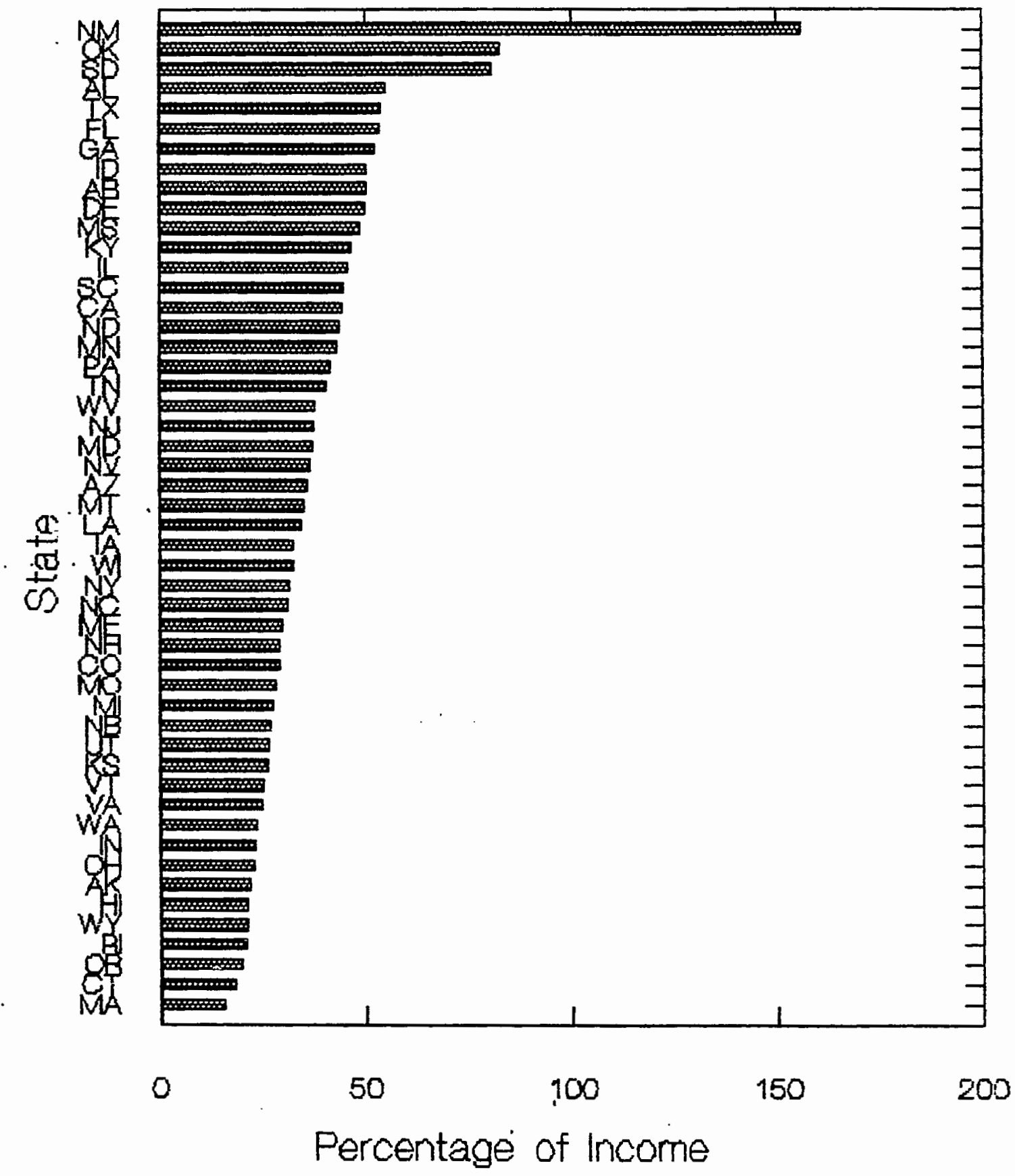

Figure 3. Taxpayer Compliance Measurement Program (TCMP) examination sample data percentage of income. 
APPENDIX B

TCMP DATA AND MODEL TAX RETURNS 
TABLE XXIV

\section{HYPOTHESIS I EXAMPLE OF TCMP DATA PREPARED FOR STATISTICAL. TESTS}

\begin{tabular}{|c|c|c|c|}
\hline PREFAREF & TAX ITEM & $\begin{array}{l}\text { CALIFOFNIA } \\
\text { CHAINGE IN }\end{array}$ & $\begin{array}{l}\text { OREGOH } \\
\text { DOLLAFS }\end{array}$ \\
\hline \multirow[t]{6}{*}{ PUELIC ACCT. } & EXEMFTION & $\$ 19.43$ & $\$ 0.00$ \\
\hline & TIF INCOME & $\$ 0.00$ & $\$ 960.47$ \\
\hline & HEDICAL INS. & $\$ 13.51$ & $\$ 0.00$ \\
\hline & OTHER MEDICAL & $\$ 343.59$ & $\$ 5.67$ \\
\hline & CASH CONT. & $\$ 39.42$ & $\$ 15.0 \%$ \\
\hline & NON-CASH CONT & 27.31 & $\neq 194.18$ \\
\hline \multirow[t]{6}{*}{ NAT'L TAX } & EXEMFTION & $\$ 122.54$ & $\$ 6.62$ \\
\hline & TIF INCOME & $\$ 470.43$ & $\$ 00.05$ \\
\hline & MEDICAL INS. & \$6.75 & $\$ 1.80$ \\
\hline & DTHEF MEDICAL & $\$ 318.60$ & $\$ 140.43$ \\
\hline & CASH CONT. & $\$ 176.48$ & $\$ 121.66$ \\
\hline & NON-CASH CONT & $\$ 41.41$ & $\$ 50.67$ \\
\hline \multirow[t]{6}{*}{ LDCAL TAX } & EXEMFTT ION & $\$ 275.04$ & $\$ 15.81$ \\
\hline & TIF INCOME & $\$ 318.47$ & $\$ .488 .84$ \\
\hline & MEDICAL INS. & $\$ 15.12$ & $\$ 3.04$ \\
\hline & OTHER MEDICAL & $\$ 194.32$ & $\$ 8.02$ \\
\hline & CASH CONT. & $\$ 89.98$ & $\$ 25.90$ \\
\hline & NON-CASH CONT & \pm 17.27 & $\$ 15.20$ \\
\hline \multirow[t]{8}{*}{ OTHEF: PAID } & EXEMPTION & $\$ 210.04$ & $\$ 0.00$ \\
\hline & TIF INCOIME & $\$ 252.77$ & $\$ 0.0$ \\
\hline & MEDICAL INS. & $\$ 25.20$ & $\$ \% .9 \%$ \\
\hline & OTHEF: MED ICAL & $\$ 414.27$ & $\$ 142.15$ \\
\hline & C.ASH CONT. & $\$ 101.9 .5$ & $\$ 0.57$ \\
\hline & NON-CASH CONT & $\$ 167.74$ & $\$ 64.89$ \\
\hline & F:ANK TOTAL & 43.061 .86 & $\$ 2.361 .94$ \\
\hline & & FERCENT & INCOME \\
\hline \multirow[t]{6}{*}{ FUELIC ACCT. } & EXEIHFTION & 0.0767 & 0.0000 \\
\hline & TIF INCOME & 0.0000 & 8.0101 \\
\hline & MEDICAL INS. & 0.0 .533 & 0.0000 \\
\hline & OTHEF FIEDICAL & 1.3556 & 0.0526 \\
\hline & CASH CONT. & 0.1555 & 0.1400 \\
\hline & NON-CASH CONT & 0.1078 & 1.8014 \\
\hline \multirow[t]{6}{*}{ NAT'L TAX } & EXEMFTION & 0.8368 & 0.0425 \\
\hline & TIF INCOME & 3.2125 & 0.5776 \\
\hline & MEDICAL INS. & 0.0458 & 0.0116 \\
\hline & DTHEF MEDICAL & 2.1761 & 0.9009 \\
\hline & CASH CONT. & 1.2052 & 0.7805 \\
\hline & NDN-CASH CONT & 0.2828 & 0.3251 \\
\hline \multirow[t]{6}{*}{ LDCAL TAX } & EXEMFTION & 1.5504 & 0.0745 \\
\hline & TIP INCOME & 1.7721 & 2.1673 \\
\hline & MEDICAL INS. & 0.0841 & 0.0135 \\
\hline & OTHEF MEDICAL & $1 ., 81:$ & 0.0355 \\
\hline & CASH CONT. & 0.5007 & 0.1148 \\
\hline & NON-CASH CONT & $0.0 \% 1$ & 0.0674 \\
\hline \multirow[t]{7}{*}{ DTHER FAID } & EXENIFTION & 1.1396 & 0.0000 \\
\hline & TIF INCOME & 1.4327 & $0.0000^{\circ}$ \\
\hline & MEDICAL INS. & 0.1427 & 0.050 \\
\hline & OTHER MEDICAL & 2.3463 & 0.8087 \\
\hline & CASH CONT. & 0.5773 & 0.0033 \\
\hline & NON-CASH CONT & 0.9501 & 0.3652 \\
\hline & F:AINK TOTAL & 21.2117 & 17.2528 \\
\hline
\end{tabular}


TABLE XXV

\section{HYPOTHESIS II EXAMPLE OF TCMP DATA PREPARED FOR STATISTICAL TESTS}

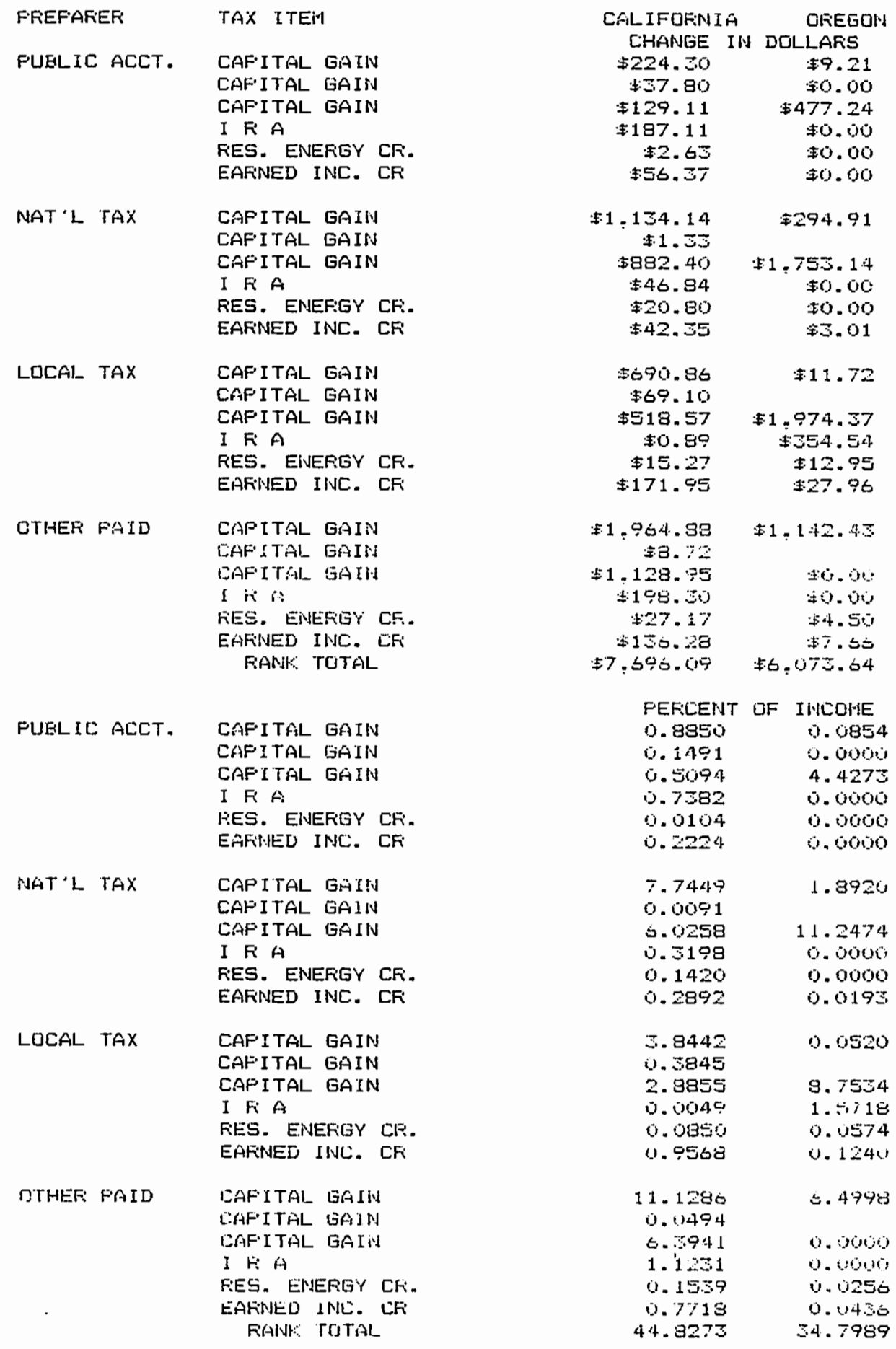


TABLE XXVI

\section{HYPOTHESIS III EXAMPLE OF TCMP DATA PREPARED FOR STATISTICAL TESTS}

\begin{tabular}{|c|c|}
\hline FFEFAAEEF & TAX ITEM \\
\hline FUELIC ACCT. & $\begin{array}{l}\text { CASUIALTY LOSS } \\
\text { MOVING EXFENSE } \\
\text { INCOME AVERAGE } \\
\text { SCHEDULE C } \\
\text { FAFIM INCOME }\end{array}$ \\
\hline NAT'L TSAX & $\begin{array}{l}\text { CASUALTY LOSS } \\
\text { MOUING EXFENSE } \\
\text { INCOHE AVESAGE } \\
\text { SCIEDULE C } \\
\text { FAFM INCOME }\end{array}$ \\
\hline LOCAL TAK & $\begin{array}{l}\text { CASUALTY LOSS } \\
\text { MOUING EXFENSE } \\
\text { INCOME AVEFAGE } \\
\text { SCHEDULE C } \\
\text { FARIM INCOME }\end{array}$ \\
\hline DTHEK FAID & 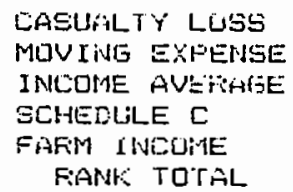 \\
\hline FUELIC ACCT. & $\begin{array}{l}\text { CASUALTY LOSS } \\
\text { MOUING EXFFEISE } \\
\text { INCOME AVEFAGE } \\
\text { SCHEDULE C } \\
\text { FARM INCOME }\end{array}$ \\
\hline NAT $\&$ I IHX & $\begin{array}{l}\text { CASUALTY LUSS } \\
\text { IIUUING EXFENSE } \\
\text { INCOME AUERTALE } \\
\text { GCHEDULE C } \\
\text { FAFM INCOME }\end{array}$ \\
\hline LOCAL TAX & $\begin{array}{l}\text { CASLIALTY LUSS } \\
\text { HUVING EXFENSE } \\
\text { INCOME AVERAGE } \\
\text { SCHEDULE C } \\
\text { FARM INCOME }\end{array}$ \\
\hline OTHEK FAID & $\begin{array}{l}\text { CASUALTY LOSS } \\
\text { MOUING EXFENSE } \\
\text { INCOHE AVEFAAGE } \\
\text { SCHEDULE C } \\
\text { FAFIM INCOME } \\
\text { FIANI: TOTAL }\end{array}$ \\
\hline
\end{tabular}

\begin{tabular}{|c|c|}
\hline CAL IFOFINIA & OFEGON \\
\hline CHANGE IN & DOLLAFS \\
\hline$\$ \$ 67 . \$ 4$ & $\$ 0.00$ \\
\hline$\$ 160.03$ & \\
\hline$\$ 71 \Xi .60$ & $\$ 2.887 .50$ \\
\hline$\$ 2.976 .89$ & $\$ 909.55$ \\
\hline$\$ 2.790 .11$ & $\$ 1.441 .9$ \\
\hline$\neq 1$. 058.50 & $\$ 191.04$ \\
\hline$\$ 505.86$ & $\$ 446.85$ \\
\hline$\$ 220.06$ & $\$ 241.47$ \\
\hline$\$ 1.720 .56$ & $\$ 1.419 .64$ \\
\hline$\$ 3$. 6003.45 & $\$ 2.521 .51$ \\
\hline$=281.57$ & \$ 14 . \\
\hline$\$ 237.11$ & $\$ 207.09$ \\
\hline$\$ 04.3 .11$ & $\$ 302.53$ \\
\hline$\$ 2.038 .80$ & $1.354 .0 \%$ \\
\hline$\$ 1.489 .84$ & $\$ 737.14$ \\
\hline$\$ .20$ & $\neq 126.86$ \\
\hline$\$ .98$ & 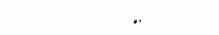 \\
\hline$\$ 30.00$ & $58 \% .56$ \\
\hline 1. . . . & 5520.78 \\
\hline$=2.557 .00$ & 5478.96 \\
\hline 524.995 .03 & $\$ 1.4 .023 .79$ \\
\hline FEFICEN & IMCOME \\
\hline 1.4493 & 0.0000 \\
\hline 0.6574 & \\
\hline 2.8155 & 26.7974 \\
\hline 11.7451 & 3.4578 \\
\hline 11.0092 & 13.3766 \\
\hline 7.2289 & 1.2256 \\
\hline 3.4545 & 2.8063 \\
\hline $1.545 \%$ & 1.5493 \\
\hline 11.7482 & 8.1078 \\
\hline 25.0175 & 16.1770 \\
\hline 1.5668 & 0.5504 \\
\hline 1.3194 & 0.9181 \\
\hline 3.5785 & 1.541 .3 \\
\hline 11.3502 & 6.0034 \\
\hline 8.2900 & उ. 20́日1 \\
\hline 0.0524 & 0.7190 \\
\hline 0.0452 & \\
\hline 2.0899 & 0.5005 \\
\hline 17.4503 & 2.9370 \\
\hline 14.4053 & 2.7244 \\
\hline 136.8563 & 99.6002 \\
\hline
\end{tabular}


TABLE XXVII

\section{HYPOTHESIS IV EXAMPLE OF TCMP DATA PREPARED FOR STATISTICAL TESTS}

\begin{tabular}{|c|c|}
\hline PREFARER & TAX ITEM/TOTAL \\
\hline FUBLIC ACCT. & $\begin{array}{l}\text { INCOME } \\
\text { ADJUSTMENTS } \\
\text { DEDUCTIONS }\end{array}$ \\
\hline NAT'L TAX & $\begin{array}{l}\text { INCOME } \\
\text { ADJUSTMENTS } \\
\text { DEDUETIINS }\end{array}$ \\
\hline LUCAL TAX & $\begin{array}{l}\text { INCONE } \\
\text { ADJUSTMENTS } \\
\text { DEDUCTI ONS }\end{array}$ \\
\hline DTHEF: FAID & $\begin{array}{l}\text { IWLOIAE } \\
\text { ADJUSTIMENTS } \\
\text { DEDUCT IONS } \\
\text { FANK TOTAL }\end{array}$ \\
\hline FUBLIC ACCT. & $\begin{array}{l}\text { INCOME } \\
\text { ADJUSTMENTS } \\
\text { DEDUCTIONS }\end{array}$ \\
\hline WAT I. TAK & $\begin{array}{l}\text { INCDVIE } \\
\text { ADJUSTMENTS } \\
\text { DEDUCTIONS }\end{array}$ \\
\hline LGCAL TAX & $\begin{array}{l}\text { IINCOME } \\
\text { ADJUSTMENTS } \\
\text { DEDUCT I UINS }\end{array}$ \\
\hline UTHEF FAID & $\begin{array}{l}\text { JNCOIAE } \\
\text { ADJUSTMENTS } \\
\text { DEDUCTIONS }\end{array}$ \\
\hline
\end{tabular}

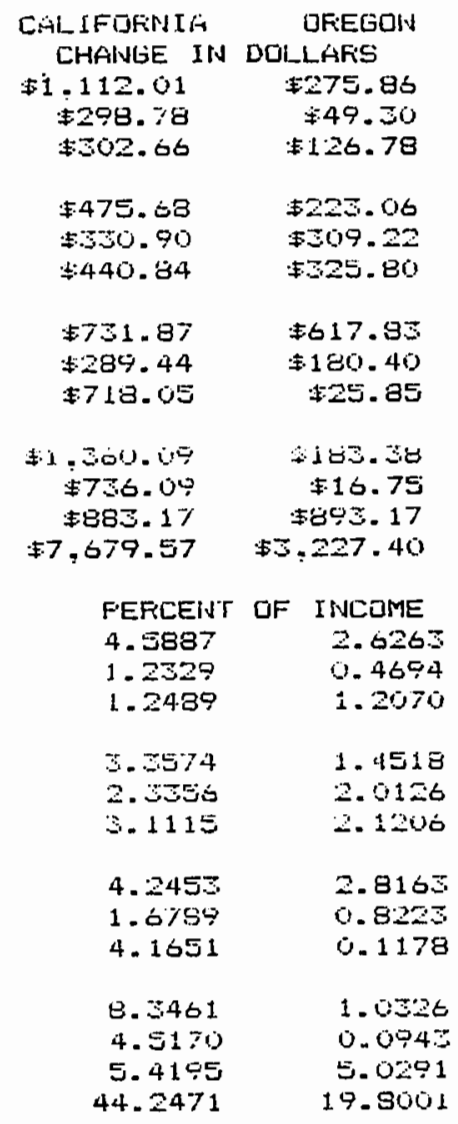


TABLE XXVIII

MODEL OF TAX RETURNS PREPARED BY ALL TYPES OF TAXPAYERS IN FIFTY STATES

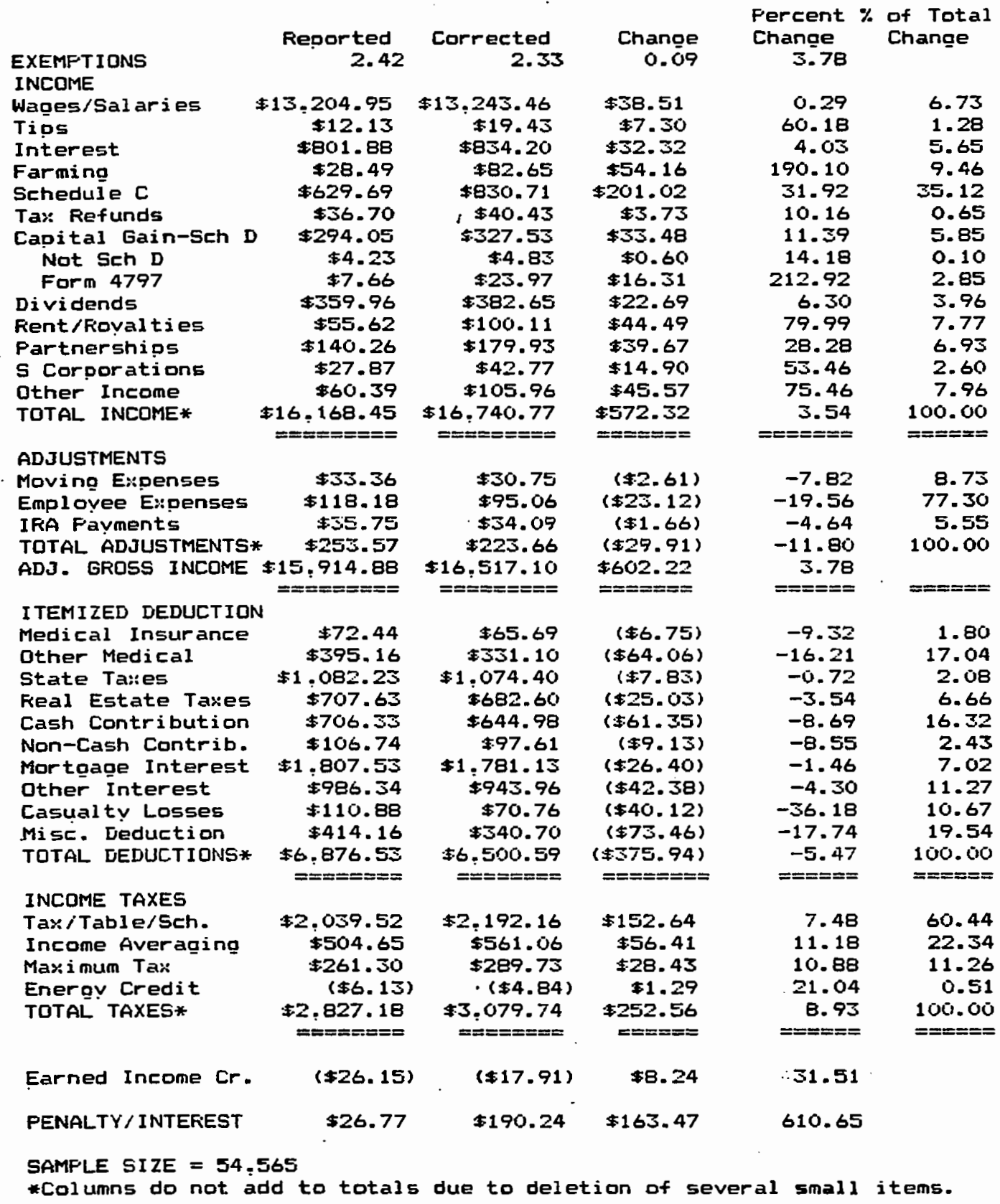


TABLE XXIX

\section{MODEL OF TAX RETURNS PREPARED BY NINE TYPES OF TAX PREPARERS IN FIFTY STATES}

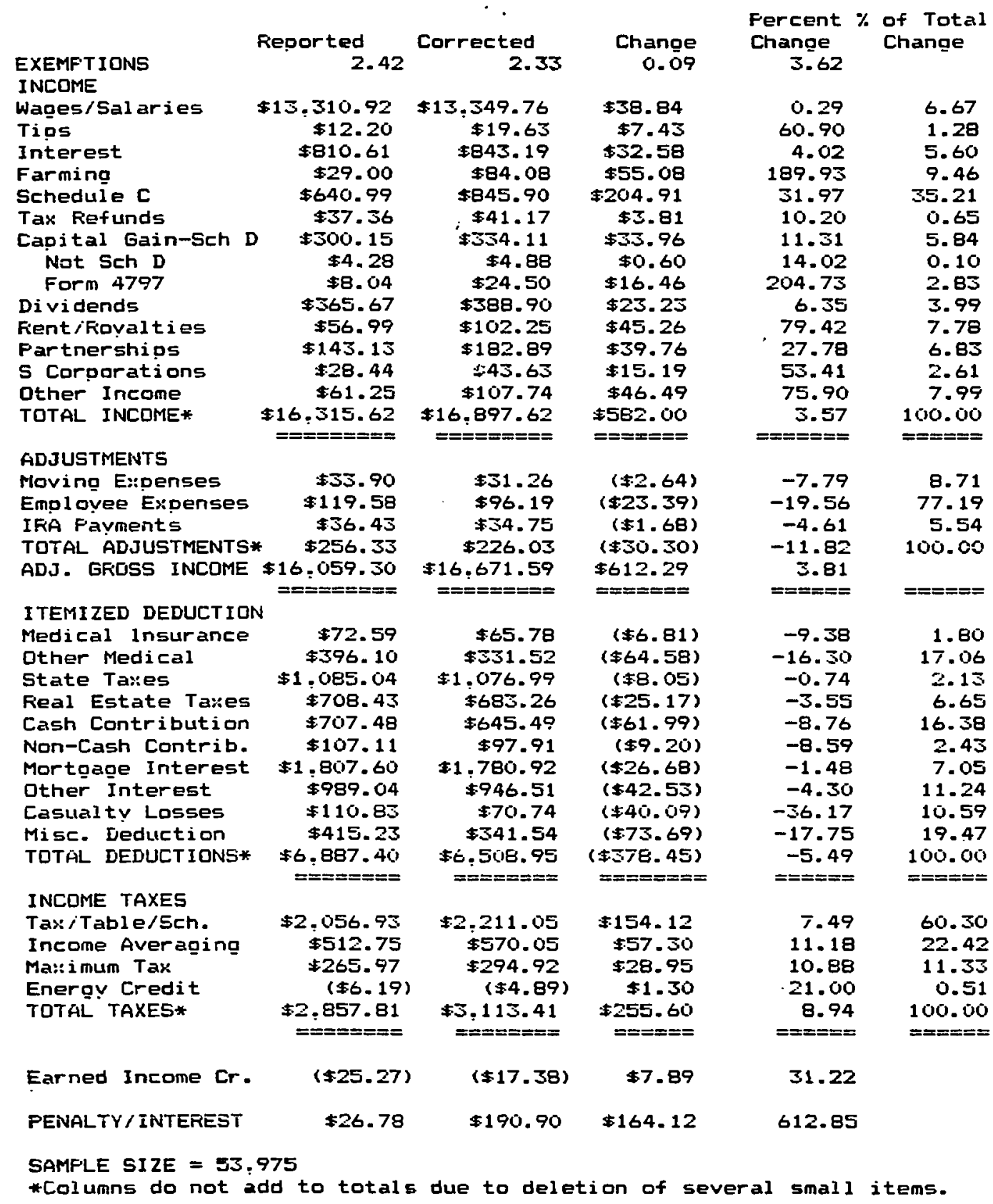


TABLE XXX

MODEL OF TAX RETURNS PREPARED BY TAXPAYERS AND UNPAID PREPARERS IN FIFTY STATES

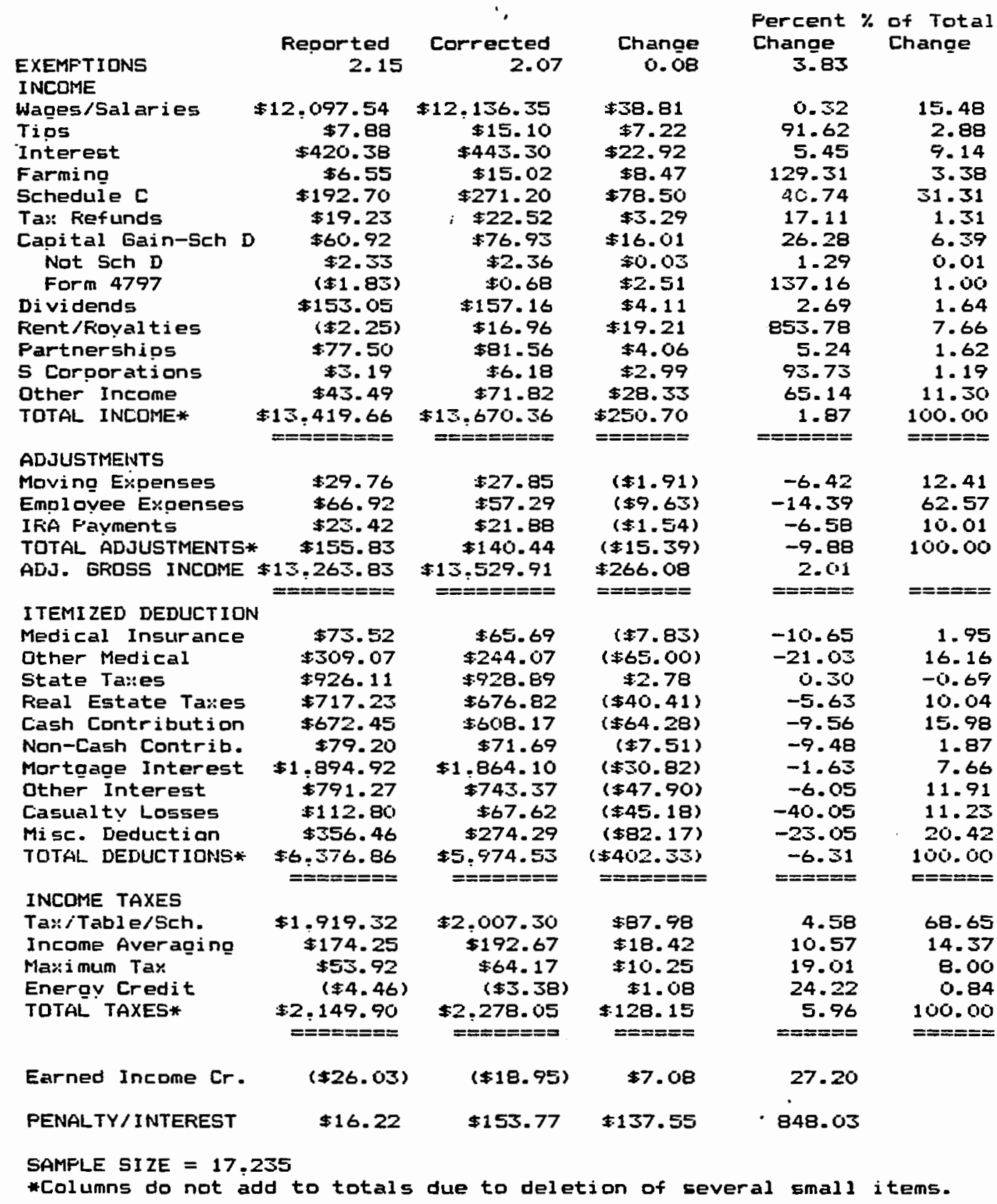


TABLE XXXI

MODEL OF TAX RETURNS PREPARED BY COMMERCIAL PREPARERS IN FIFTY STATES

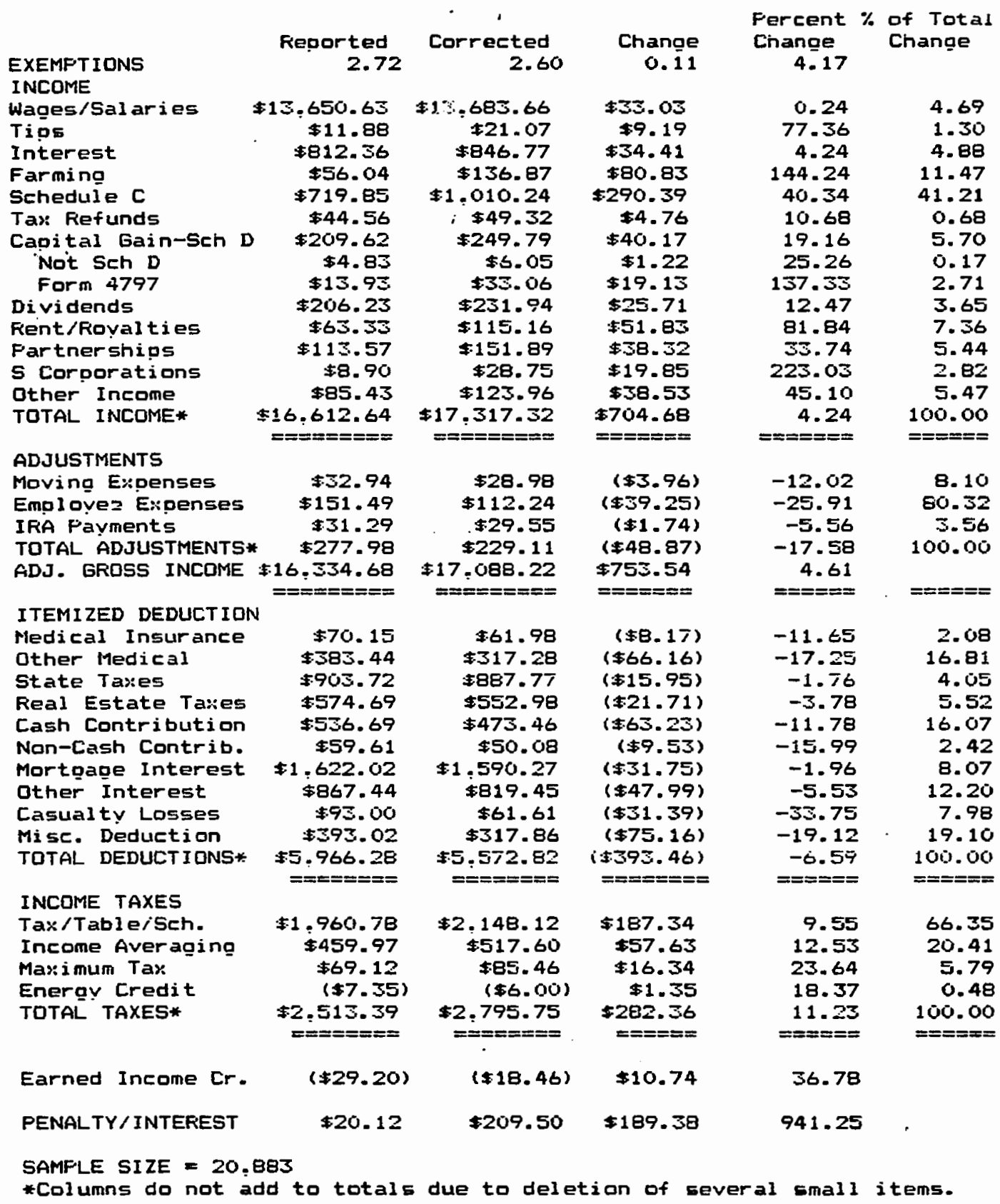


TABLE XXXII

MODEL OF TAX RETURNS PREPARED BY PROFESSIONAL PREPARERS IN FIFTY STATES

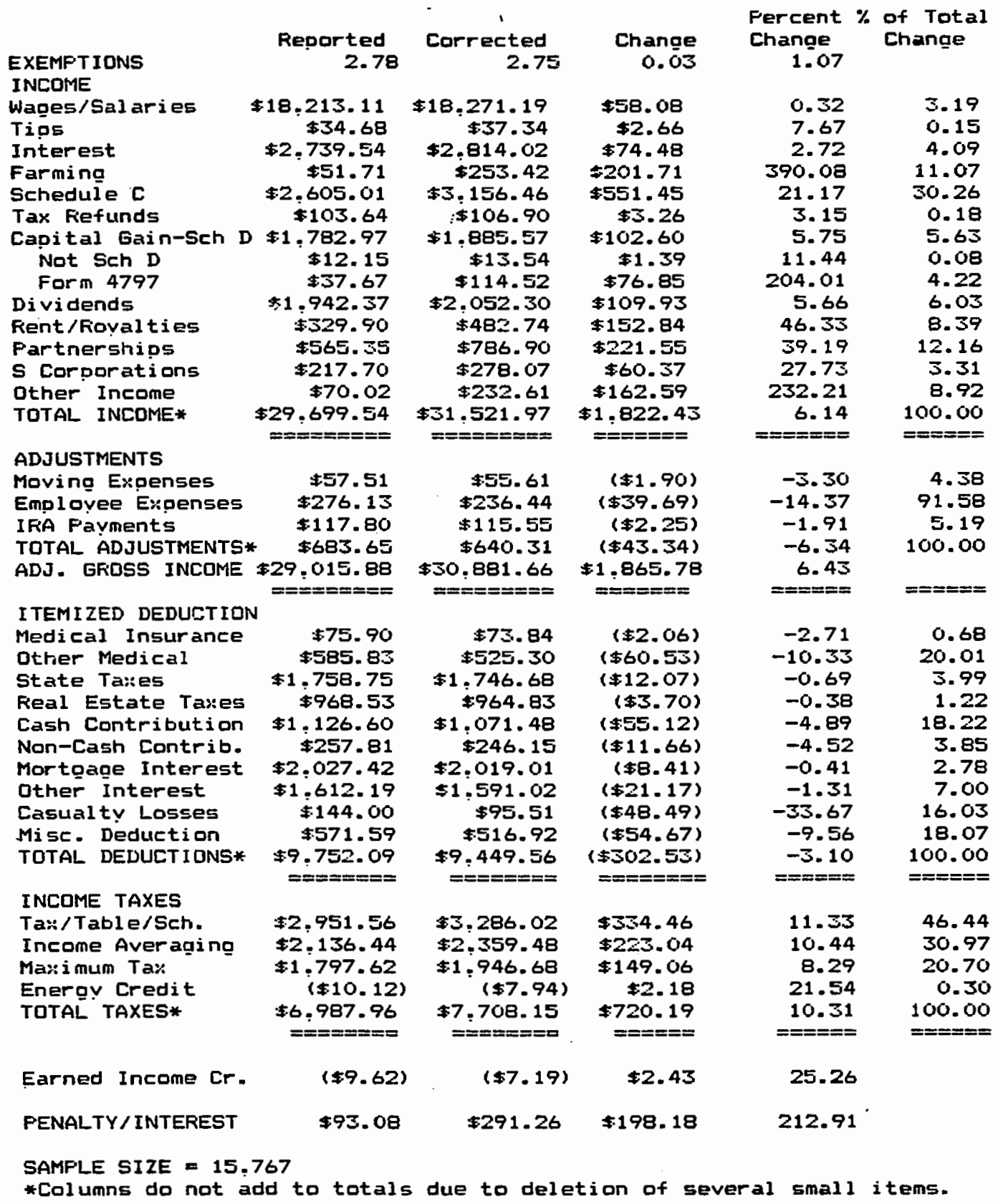


TABLE XXXIII

MODEL OF TAX RETURNS PREPARED BY COMMERCIAL PREPARERS IN ARIZONA

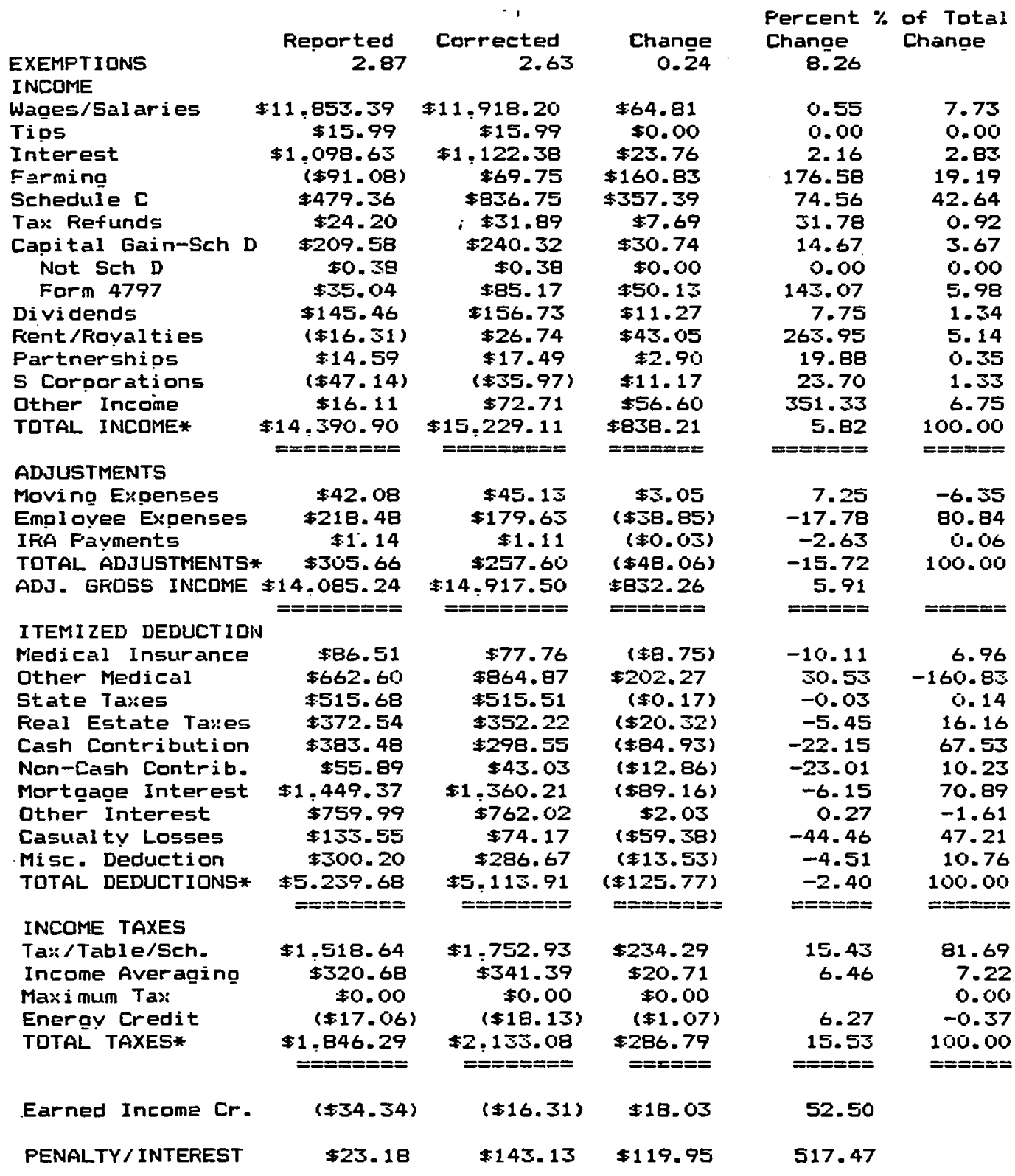

*Columns do not add to totals due to deletion of several small items. 
TABLE XXXIV

MODEL OF TAX RETURNS PREPARED BY COMMERCIAL PREPARERS IN CALIFORNIA

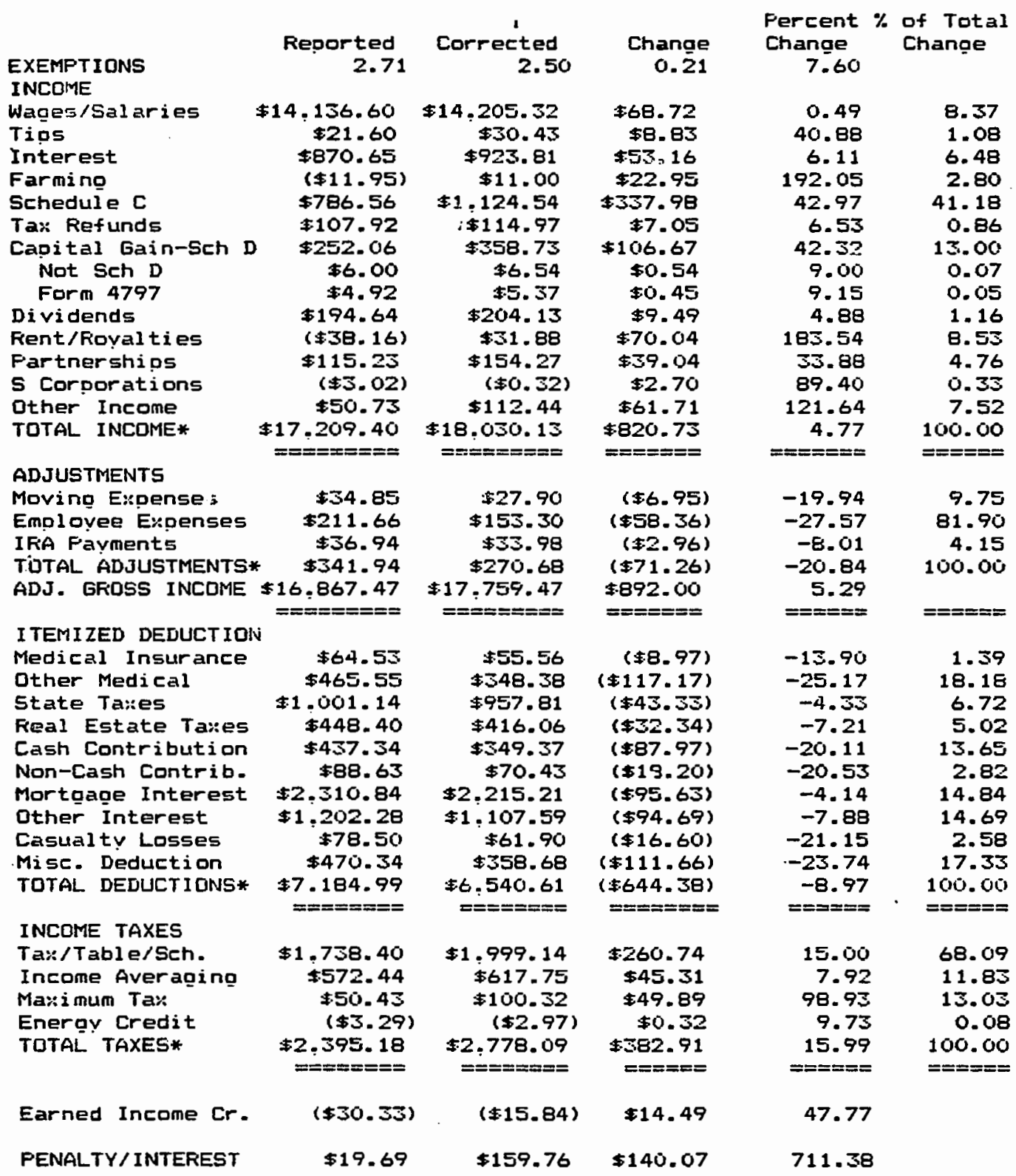

*Columns do not add to totals due to deletion of several small items. 
TABLE XXXV

\section{MODEL OF TAX RETURNS PREPARED BY COMMERCIAL PREPARERS IN FLORIDA}

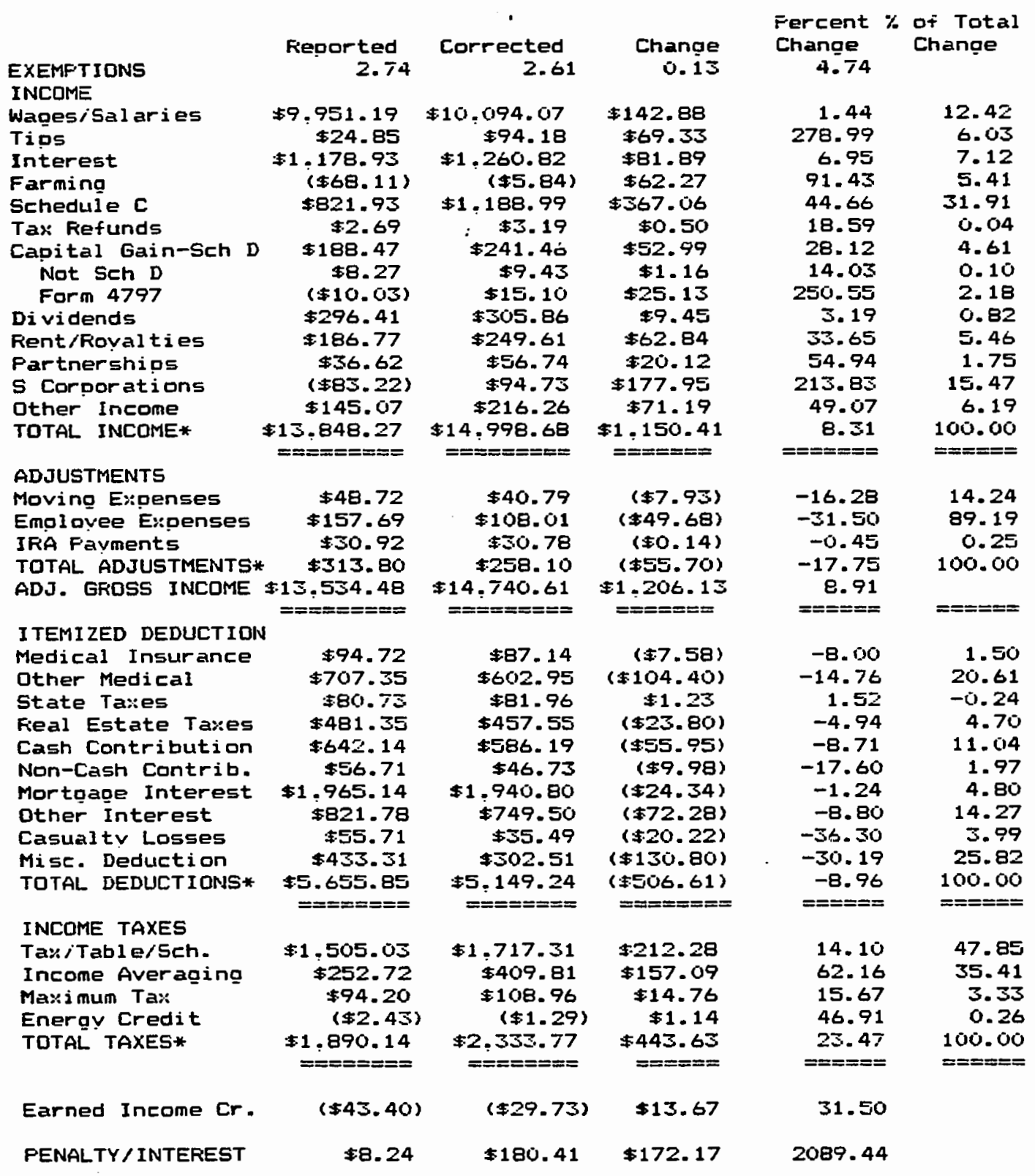

* Columns do not add to totals due to deletion of several small items. 
TABLE XXXVI

MODEL OF TAX RETURNS PREPARED BY COMMERCIAL PREPARERS IN HAWAI I

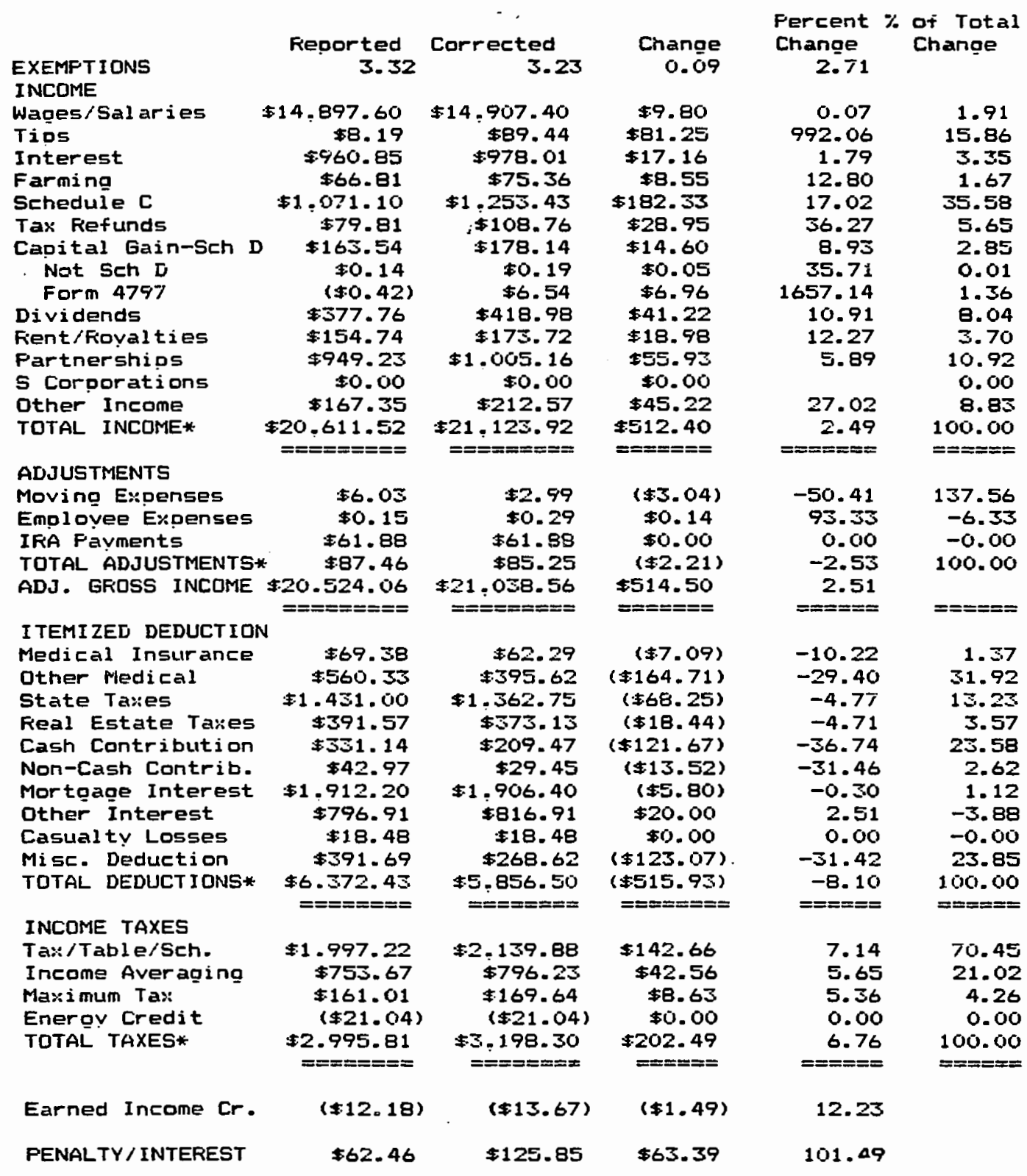

* Columns do not add to totals due to deletion of several small items. 
TABLE XXXVII

MODEL OF TAX RETURNS PREPARED BY COMMERCIAL PREPARERS IN RANSAS

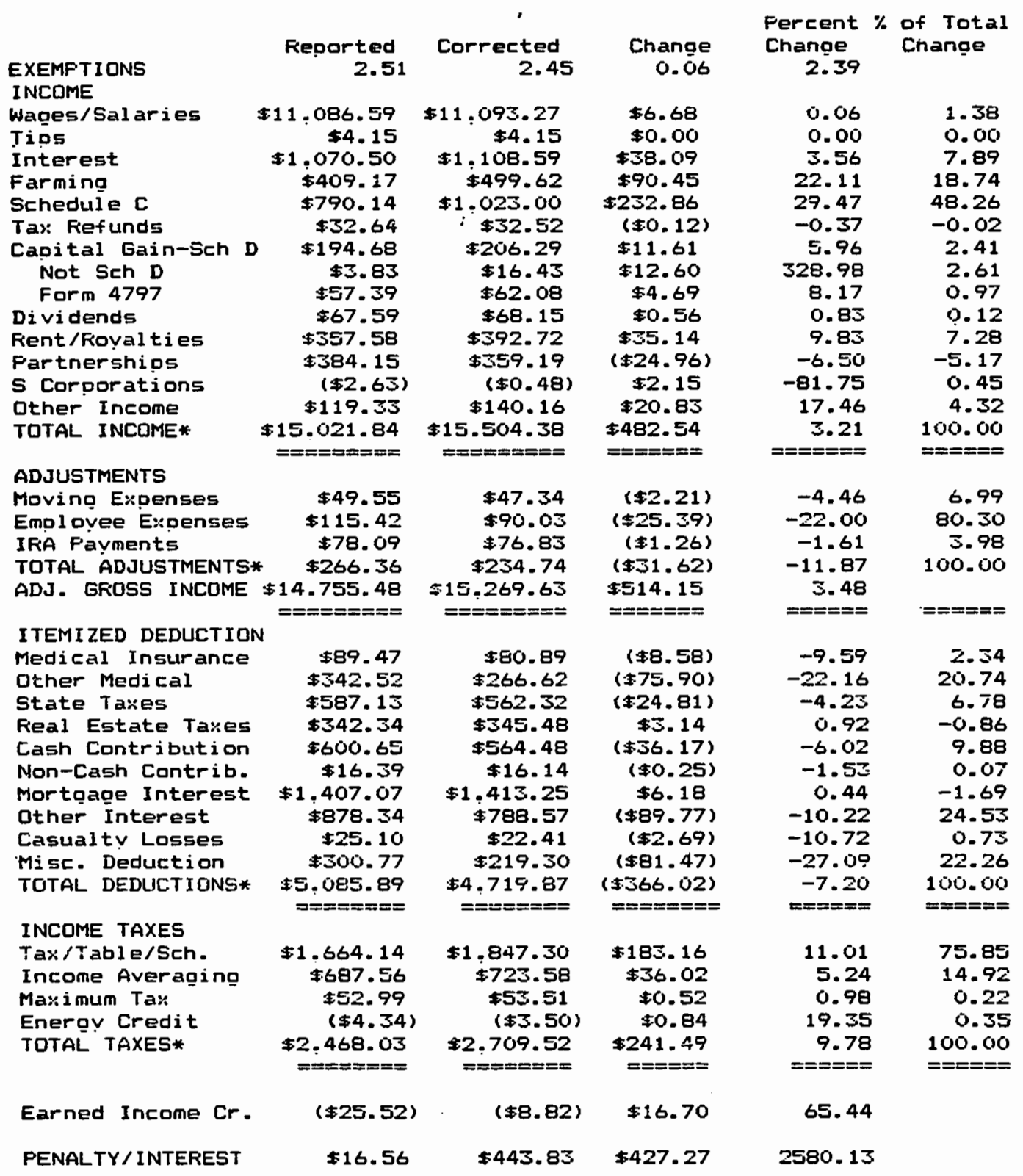

* Columns da not add to totals due to deletion of several small items. 
TABLE XXXVIII

MODEL OF TAX RETURNS PREPARED BY COMMERCIAL PREPARERS IN RENTUCKY

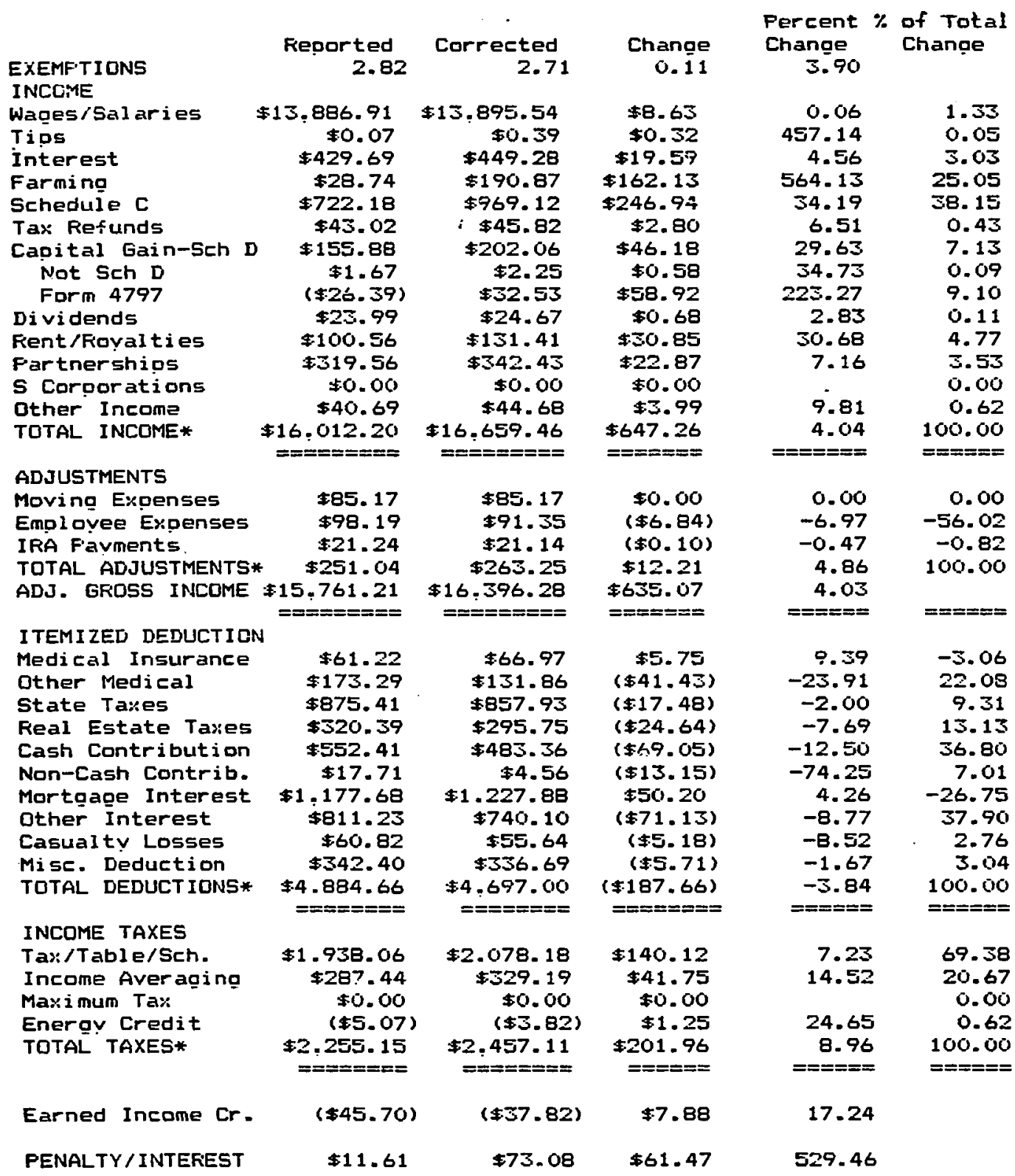

* Columns do not add to totals due to deletion of several small items. . 
TABLE XXXIX

\section{MODEL OF TAX RETURNS PREPARED BY COMMERCIAL PREPARERS IN MASSACHQUSETTS}

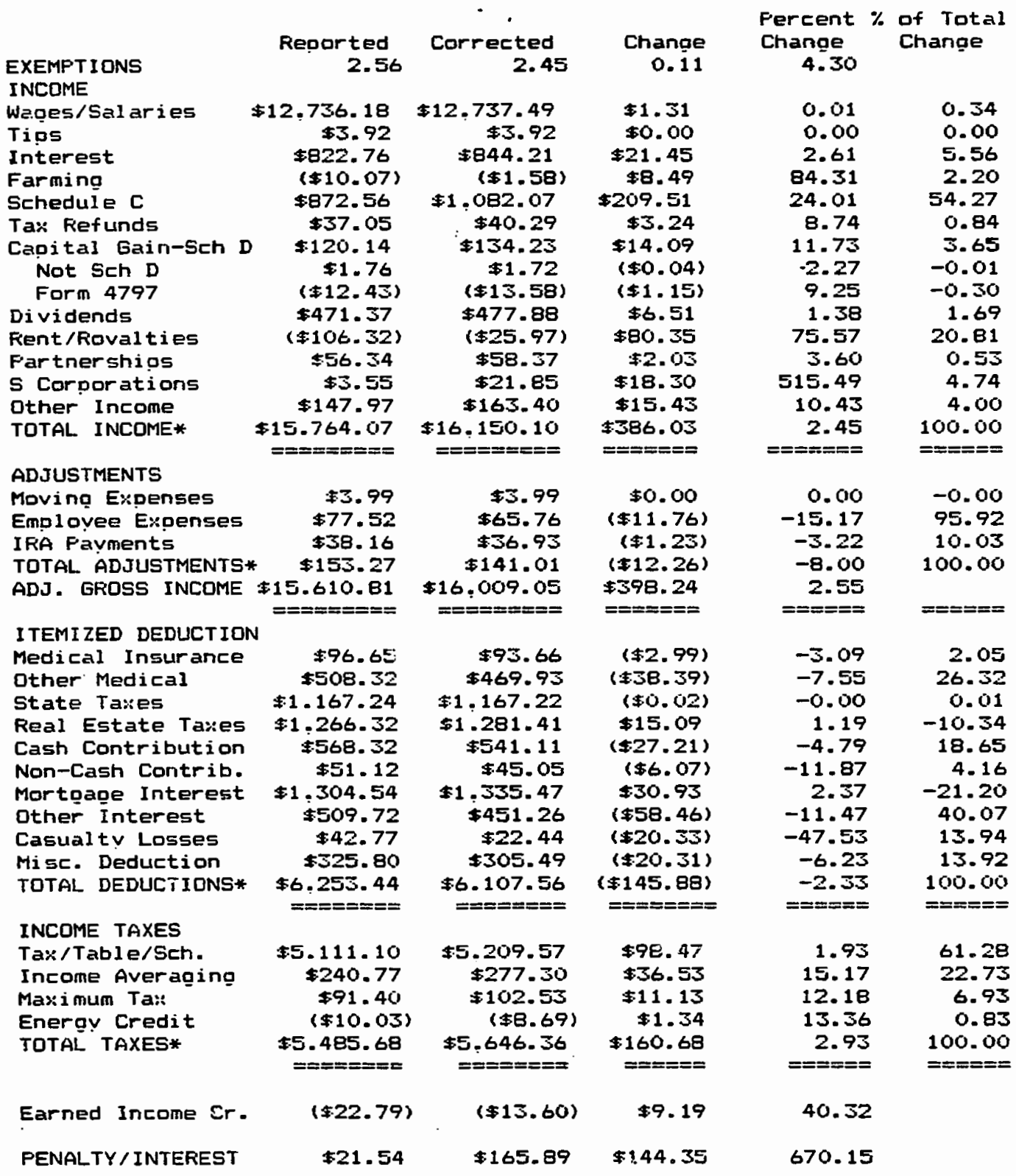


TABLE XL

MODEL OF TAX RETURNS PREPARED BY COMMERCIAL PREPARERS IN NEBRASRA

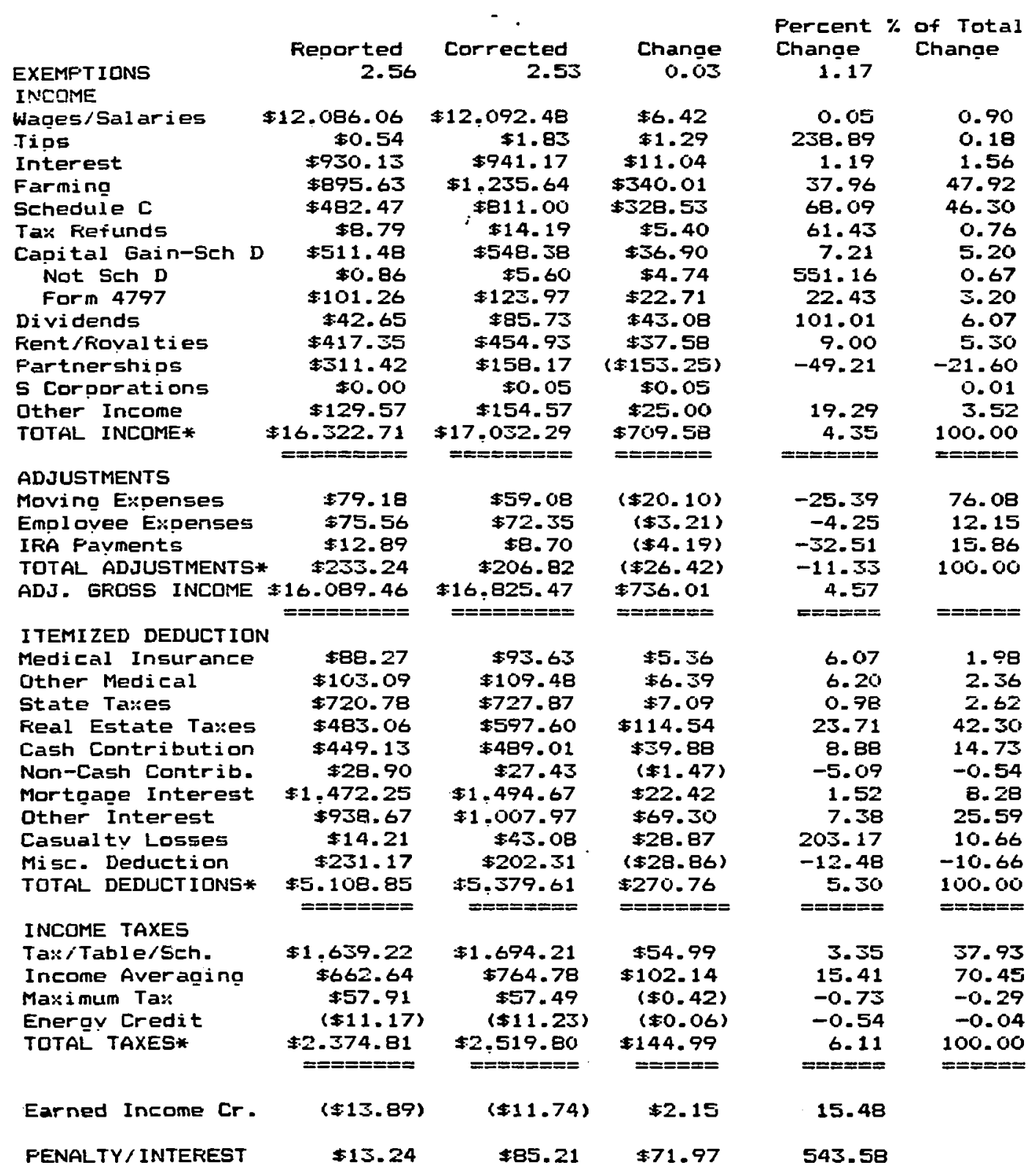

* Columnis do not add to totals due to deletion of several small items. 
TABLE XLI

MODEL OF TAX RETURNS PREPARED BY COMMERCIAL PREPARERS IN NEW MEXICO

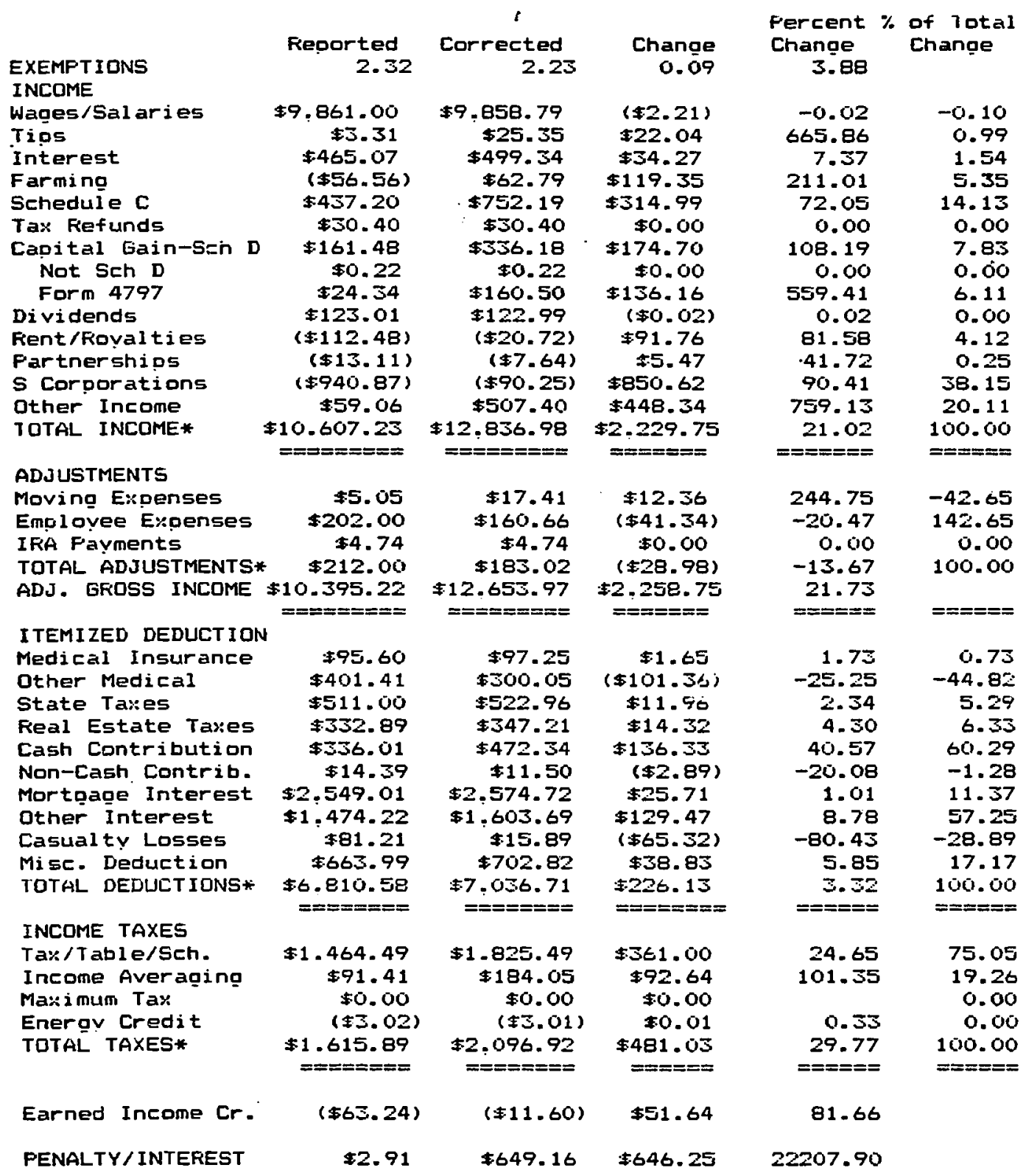

*Columns do not add to totals due to deletion of sevaral small items. 
TABLE XLII

MODEL OF TAX RETURNS PREPARED BY COMMERCIAL PREPARERS IN
NEW YORK

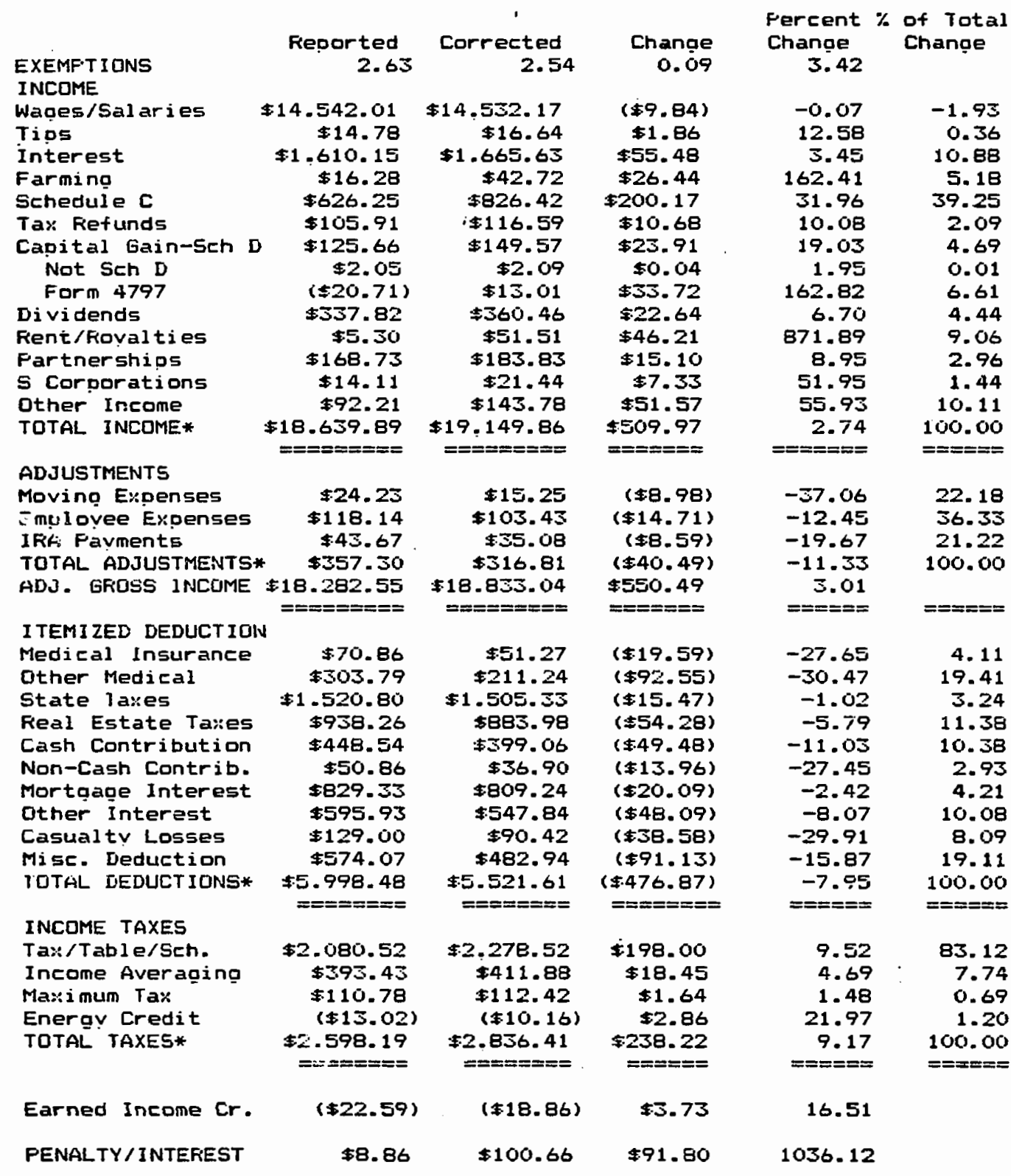

* Columns do not add to totals due to deletion of several small items. 
TABLE XLIII

MODEL OF TAX RETURNS PREPARED BY COMMERCIAL PREPARERS IN NORTH DAROTA

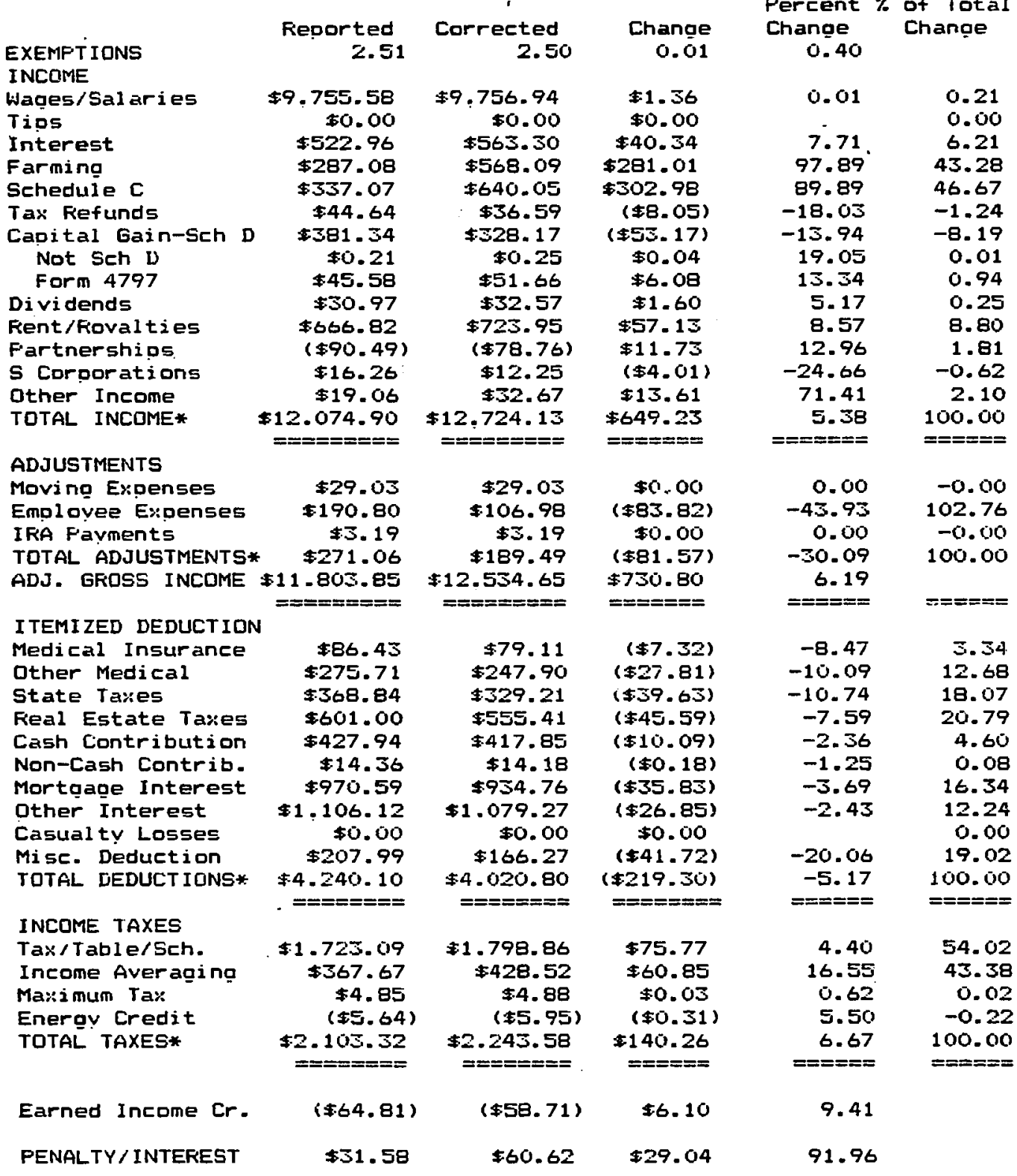

* Columns do not add to totals due to deletion of several small items. 
TABLE XLIV

\section{MODEL OF TAX RETURNS PREPARED BY COMMERCIAL PREPARERS IN} OREGON

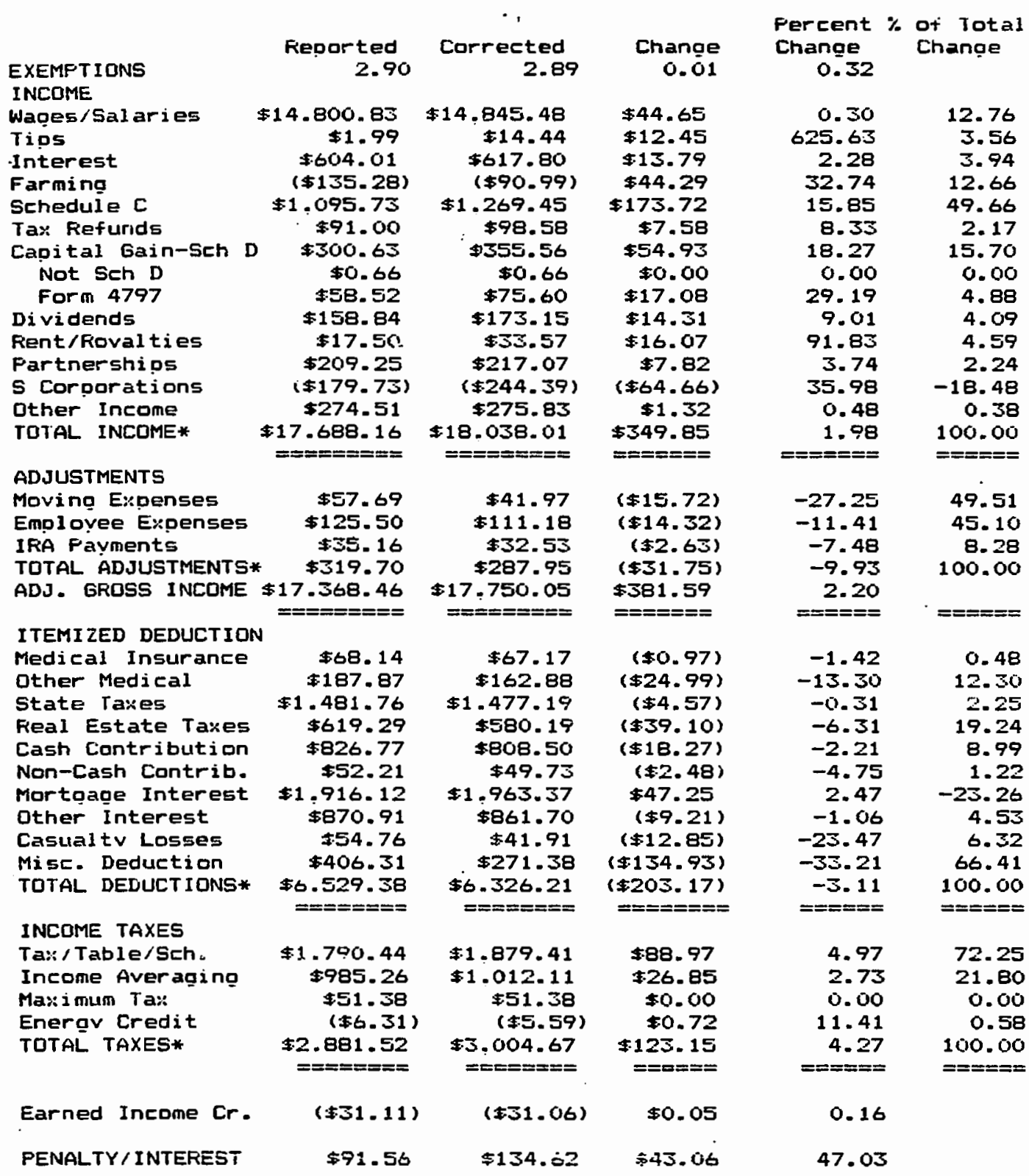

* Columns do not add to totals oue to deletion of several small items. 
TABLE XLV MODEL OF TAX RETURNS PREPARED BY COMMERCIAL PREPARERS IN
VIRGINIA

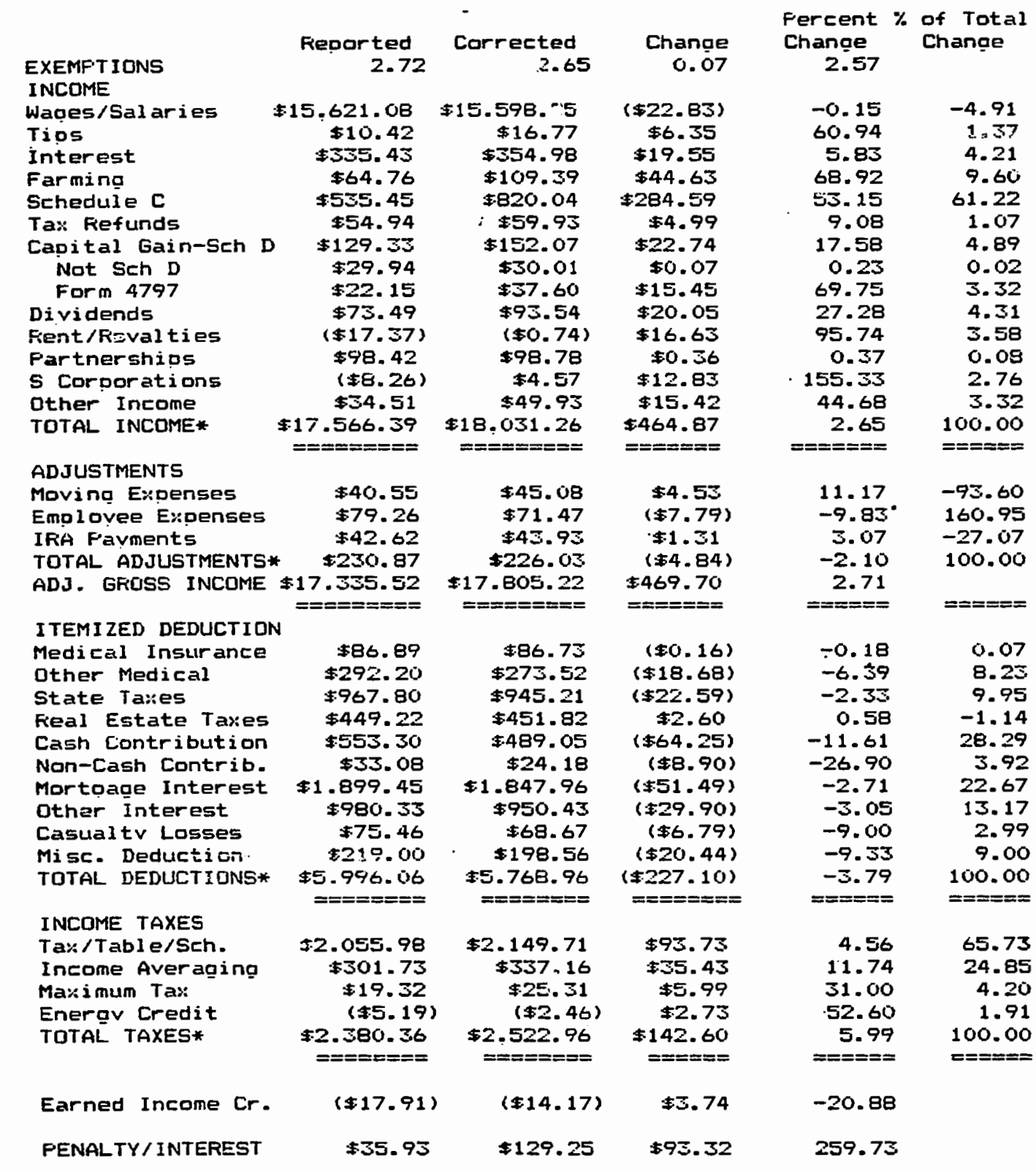

* Columns do not add to totals due to deletion of several small items. 
TABLE XLVI

MODEL OF TAX RETURNS PREPARED BY COMMERCIAL PREPARERS IN WASHINGTON

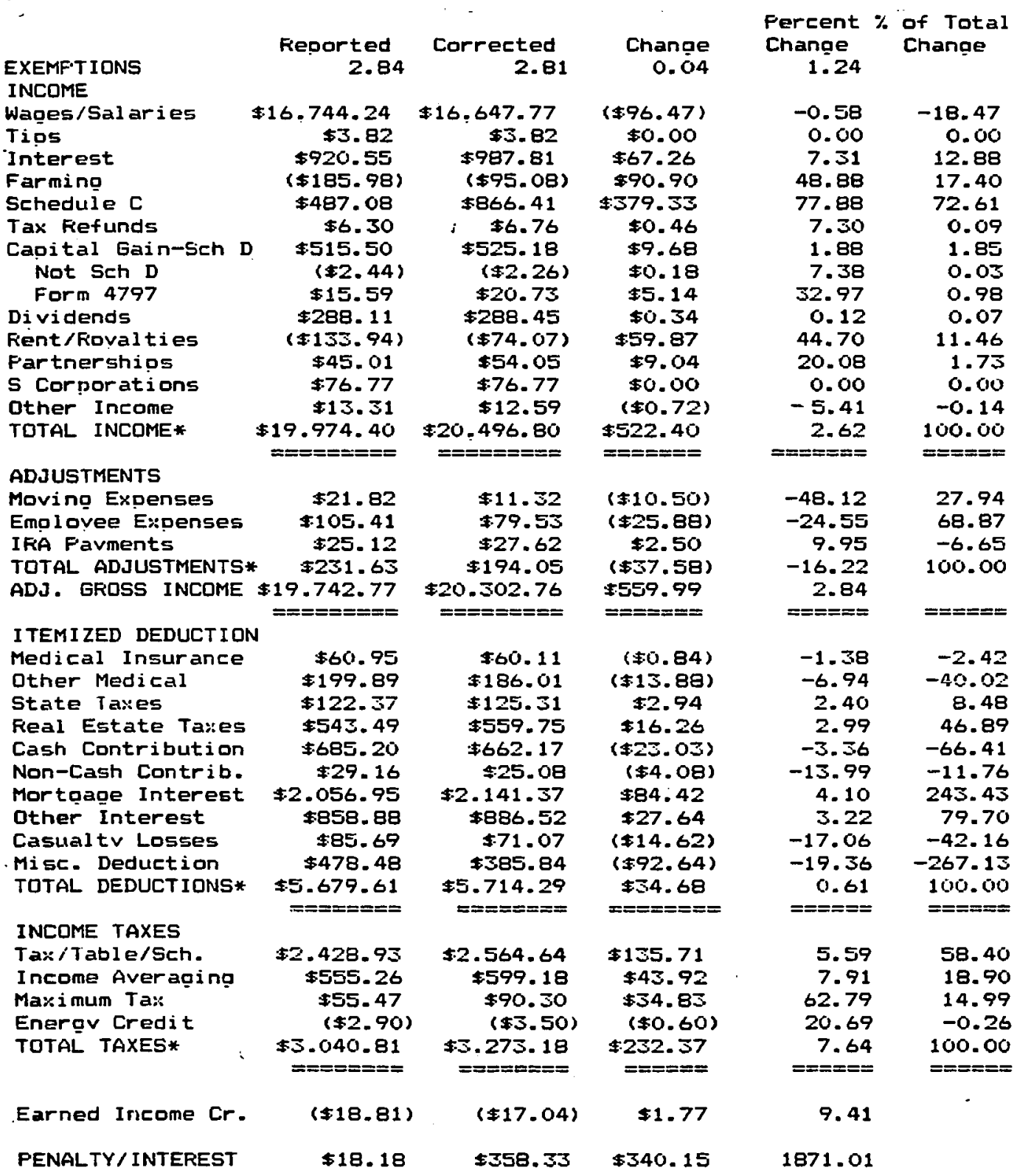

*Columns do not add to totals due to deletion of several small items. 
TABLE XLVII

MODEL OF TAX RETURNS PREPARED BY COMMERCIAL PREPARERS IN WISCONS IN

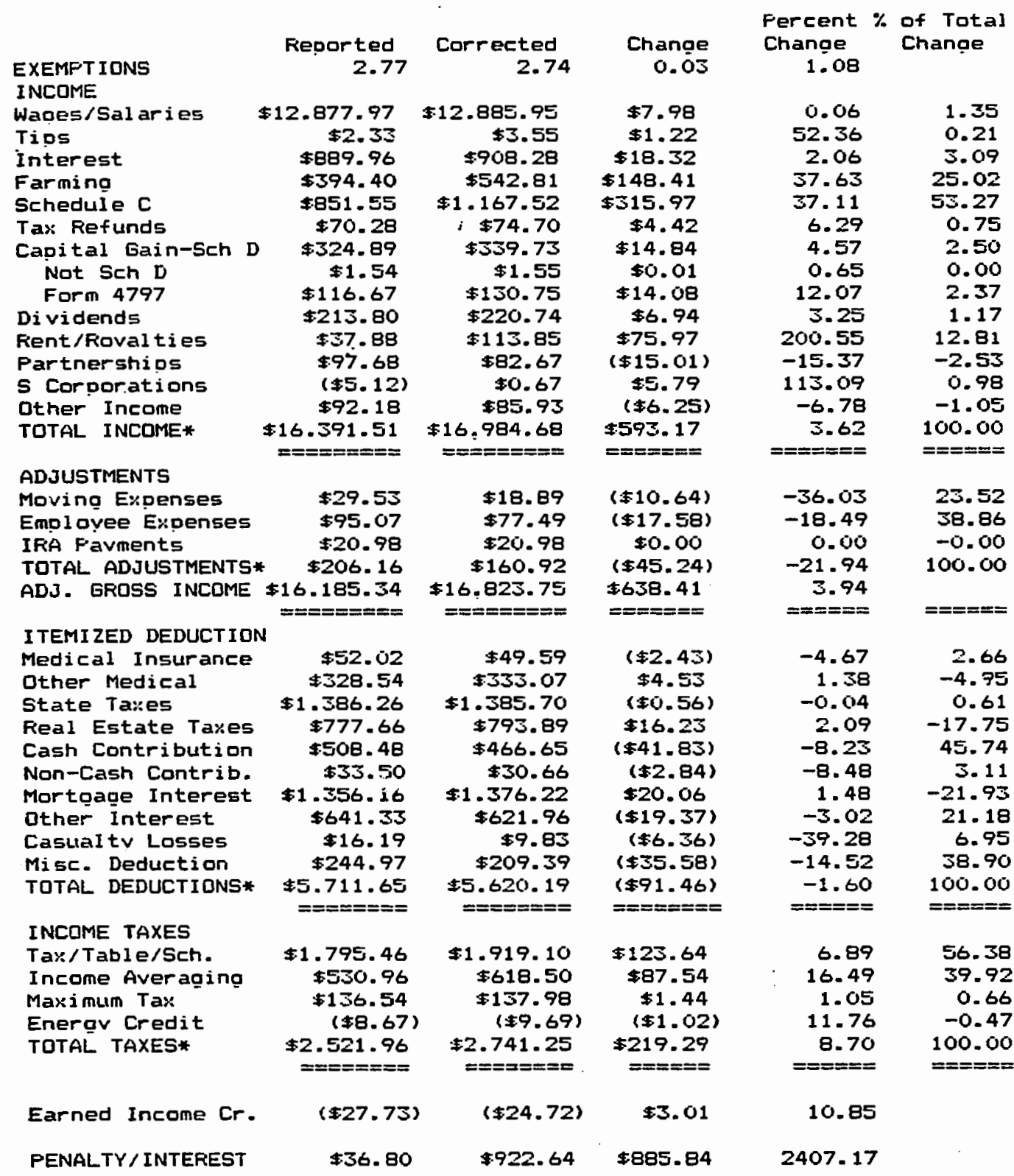

* Columns do not add to totals due to dection of several small items. 
APPENDIX C

DENSITY STRIPE GRAPHS AND CLUSTER ANALYSIS 


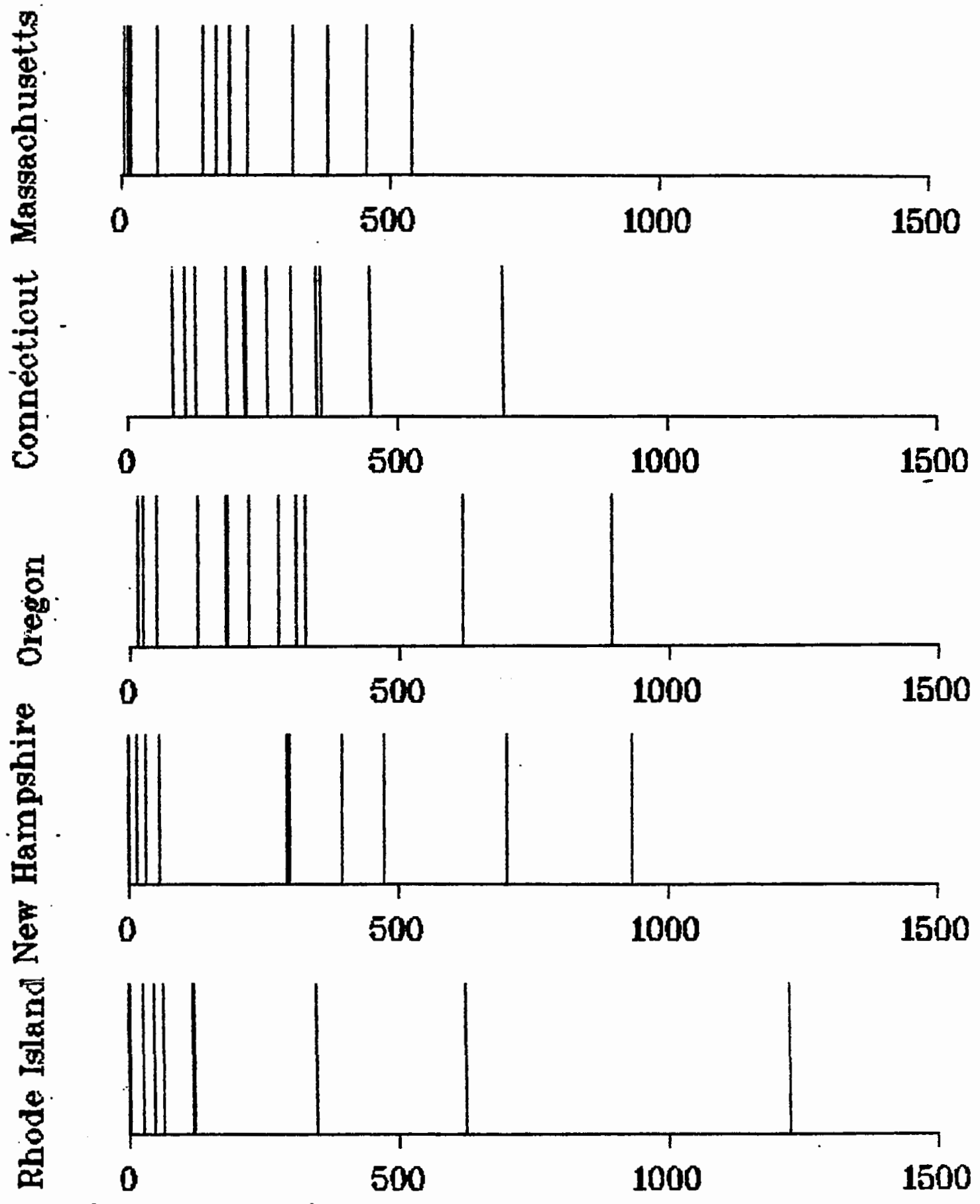

Figure 4. Comparison of sample from Oregon and selected northeastern states. 


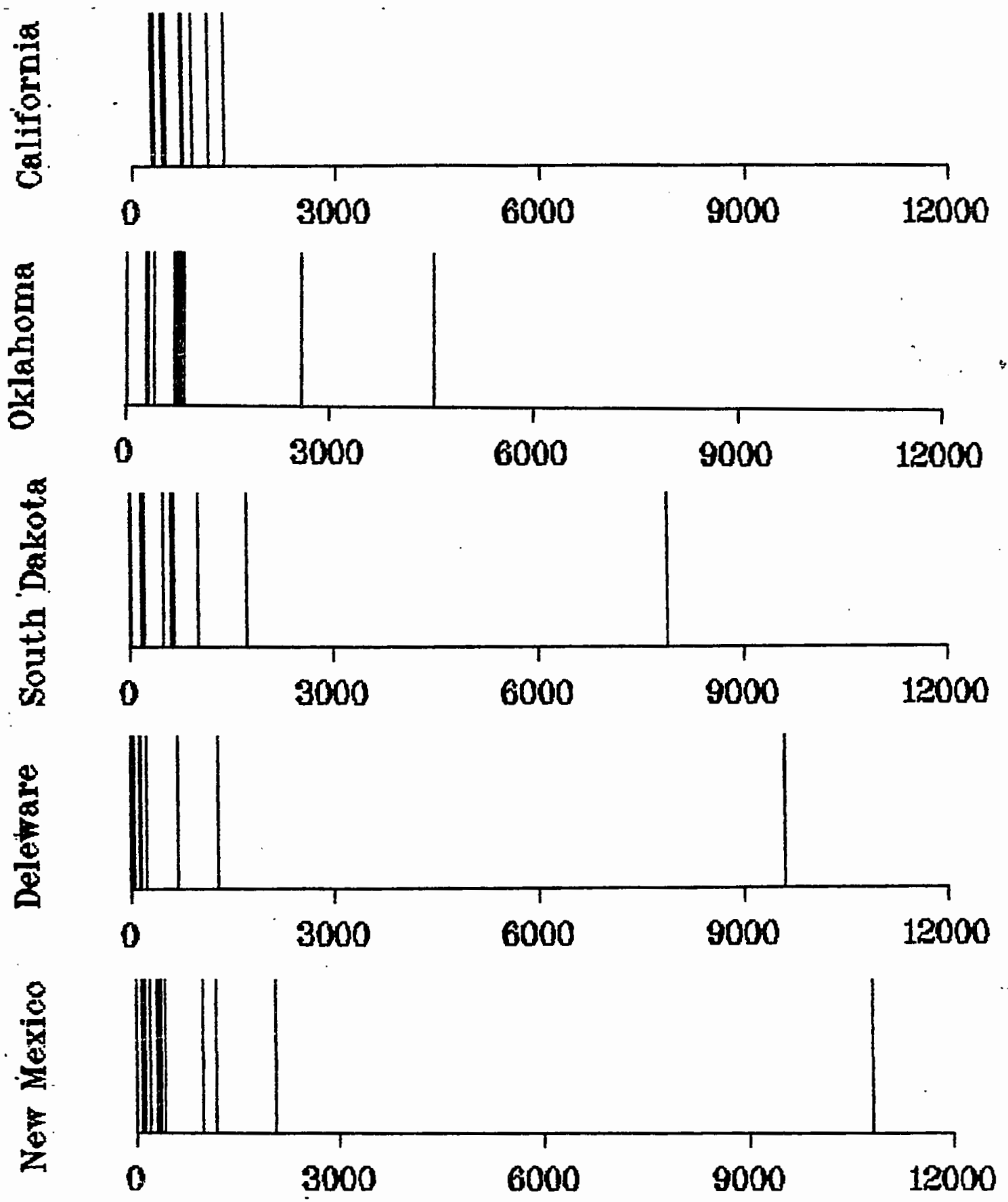

Figure 5. Comparison of sample data from California and states with highest average errors. 
DISI NNLEF HEIRIL IS EULA IDEAN DISINACE AUERRGE LIHIAUE HE HUU:

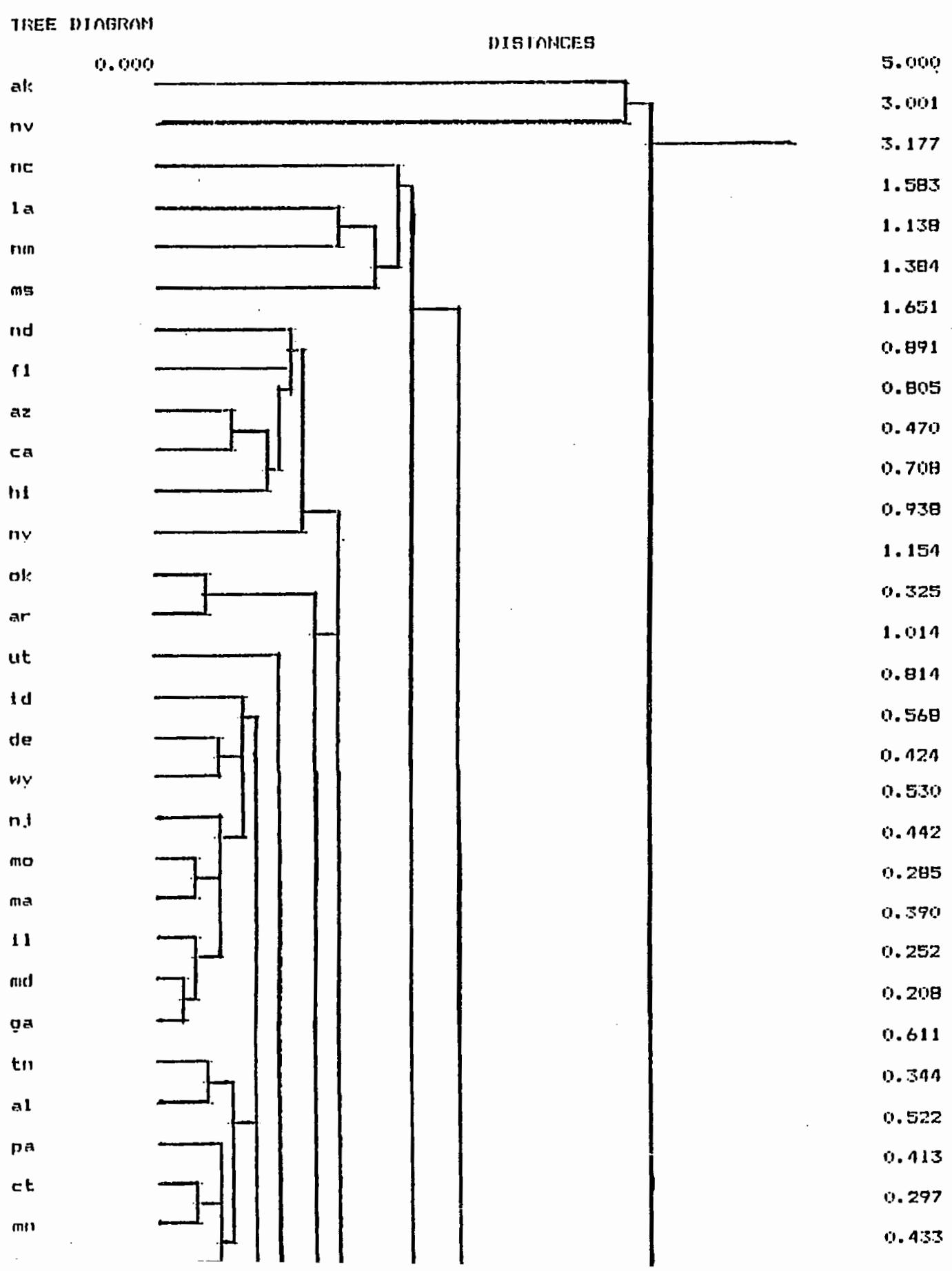




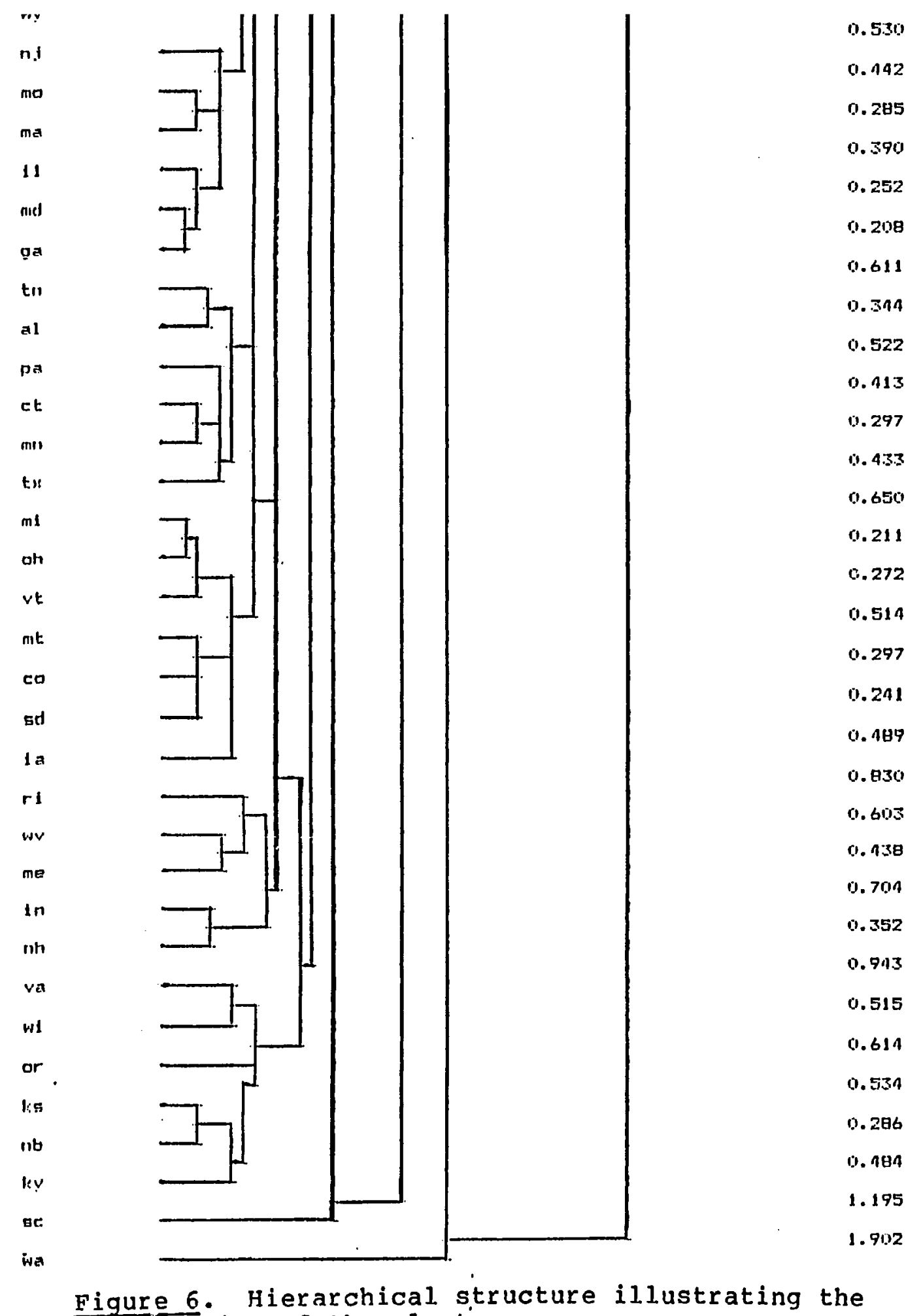

Figure 6. Hierarchical structure illustrating the nartitioning of the clusters. 
SUMMARY STATISTICS FOR 12 CLUSTERS

\begin{tabular}{rrrrrrr} 
VARIABLE & BETWEEN SS & DF & WITHIN SS & DF & F-RATIO & FROB \\
FINC1 & 44.882 & 11 & 4.118 & 38 & 37.656 & 0.000 \\
FINC2 & 40.380 & 11 & 8.620 & 38 & 16.182 & 0.000 \\
FINC3 & 36.232 & 11 & 12.768 & 38 & 9.803 & 0.000 \\
FINC4 & 43.343 & 11 & 5.657 & 38 & 26.470 & 0.000 \\
FETEX & 39.858 & 11 & 9.142 & 38 & 15.061 & 0.000 \\
ADDTAX & 35.065 & 11 & 13.935 & 38 & 8.693 & 0.000 \\
ADMCOST & 38.103 & 11 & 10.897 & 38 & 12.080 & 0.000 \\
\hline
\end{tabular}

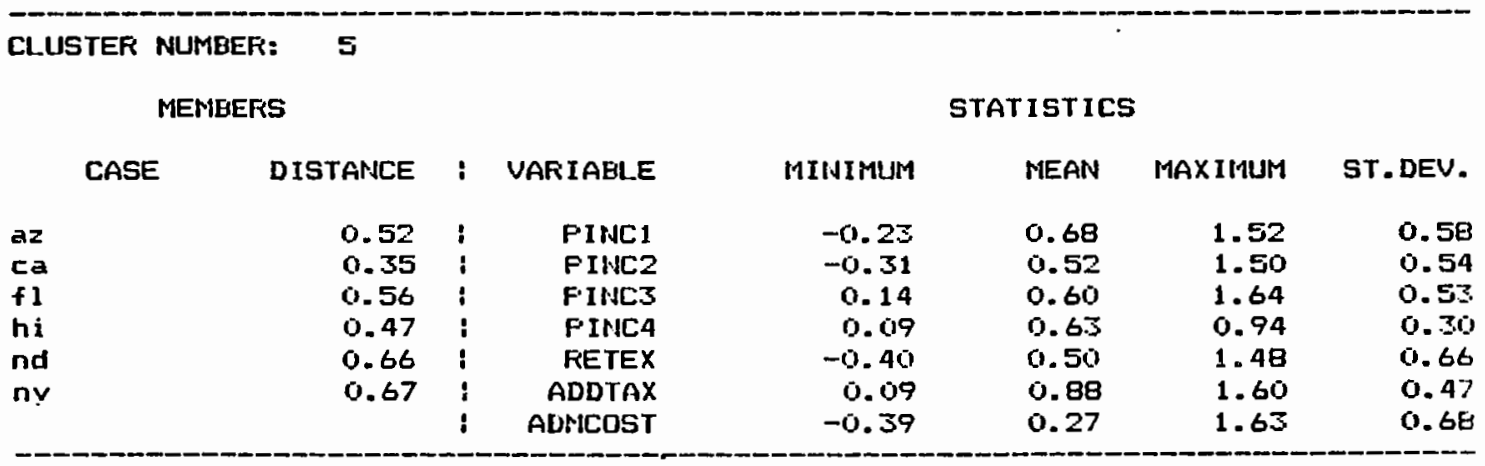

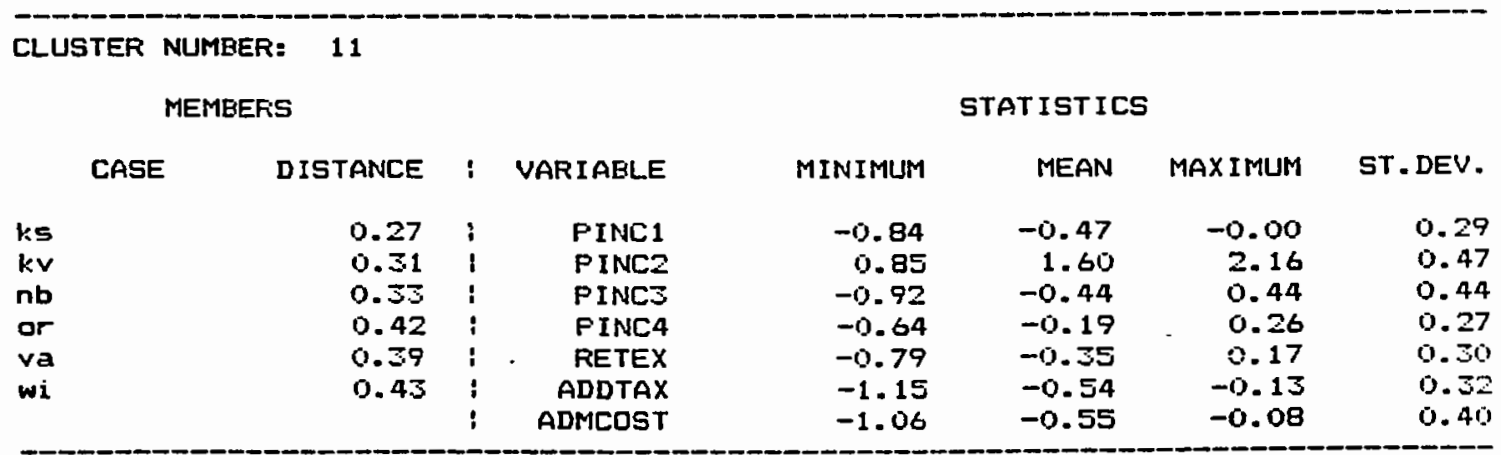

Figure 7. Summary statistics for $\mathrm{R}$-means cluster analysis. 


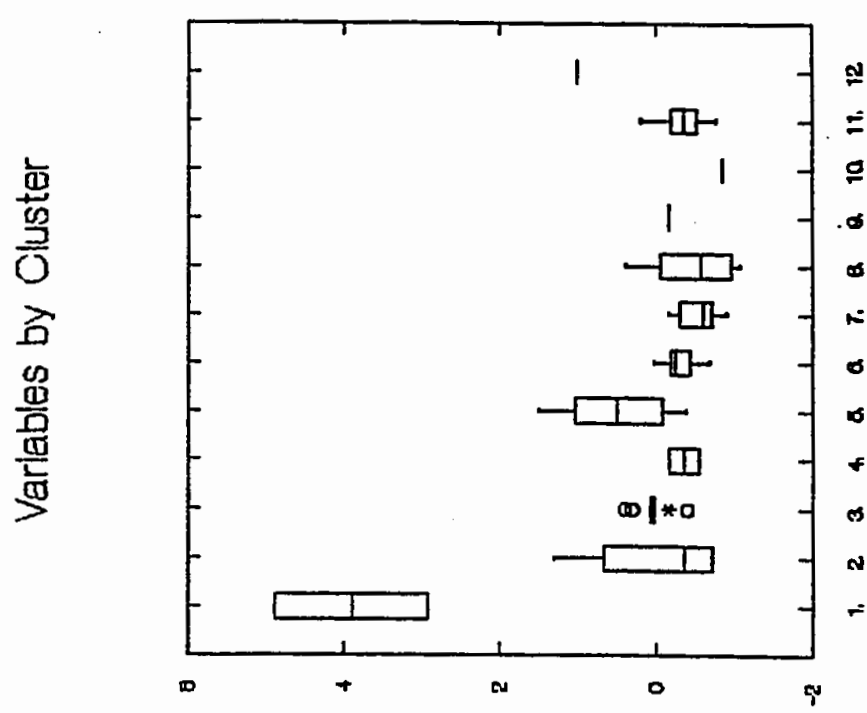

penpmy sumsit to әbęuә0.d

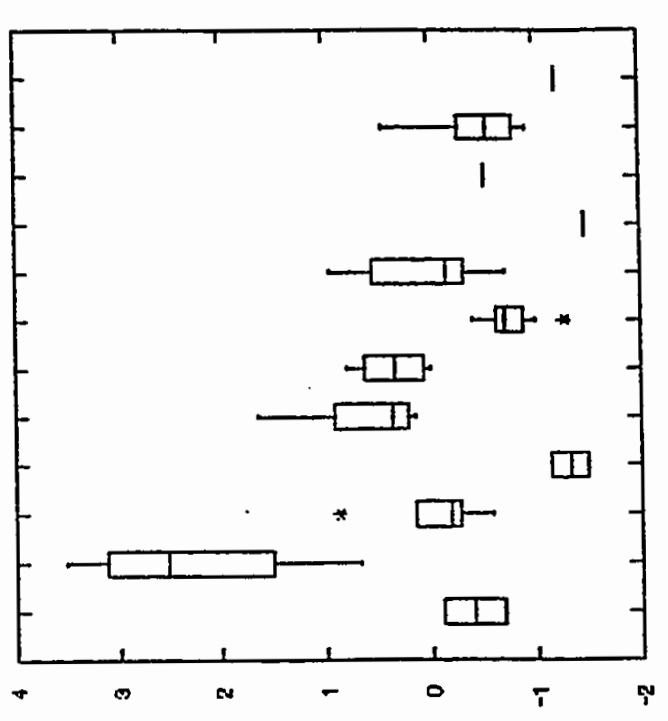

aburey suoponpad 18701

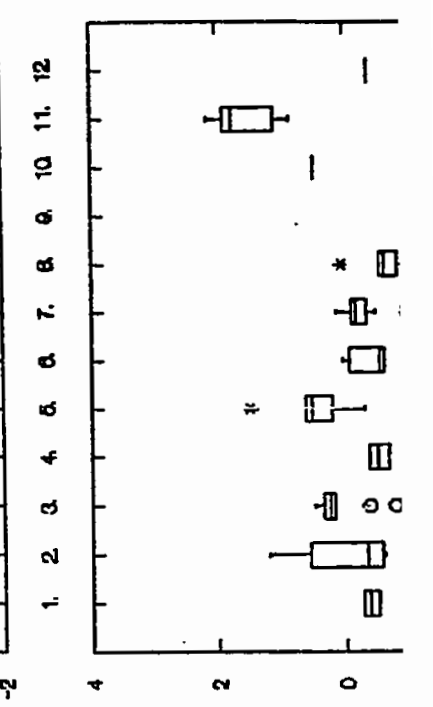

abiren slue

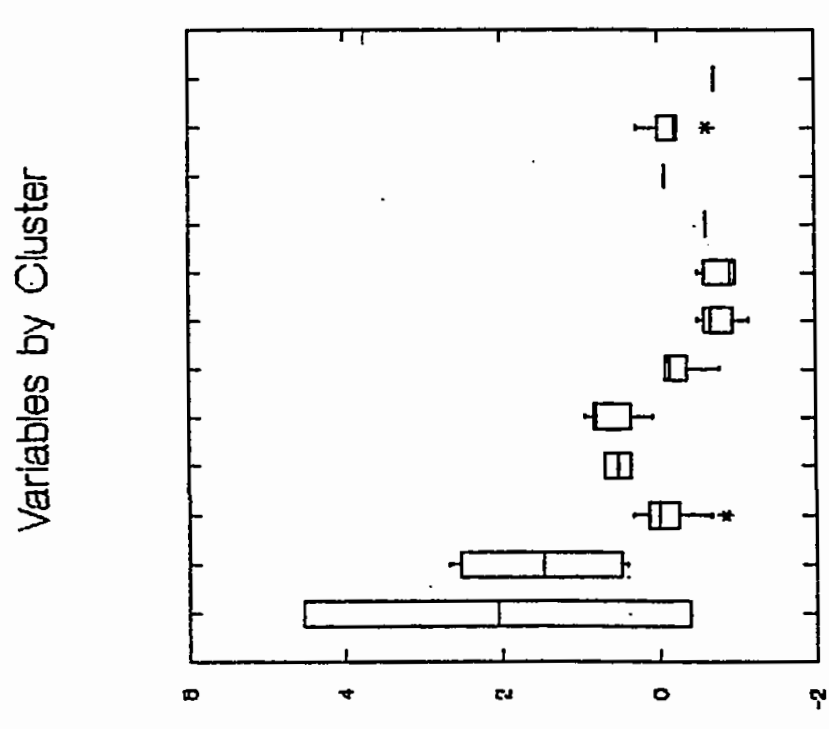

abueto XeI IETOL

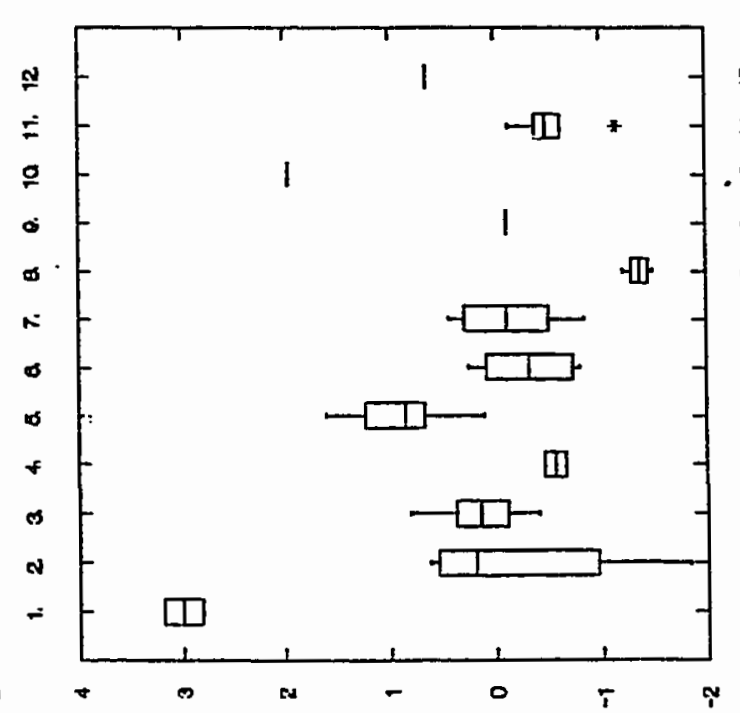

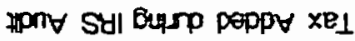

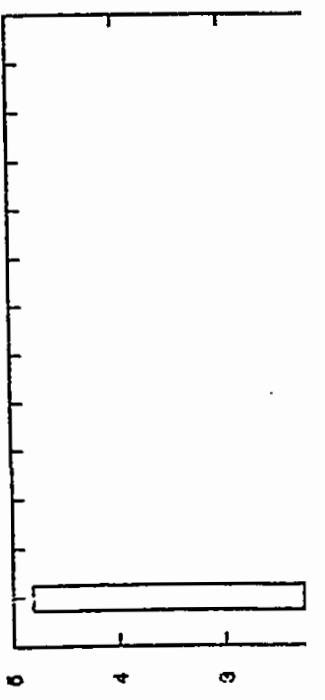

soueup 


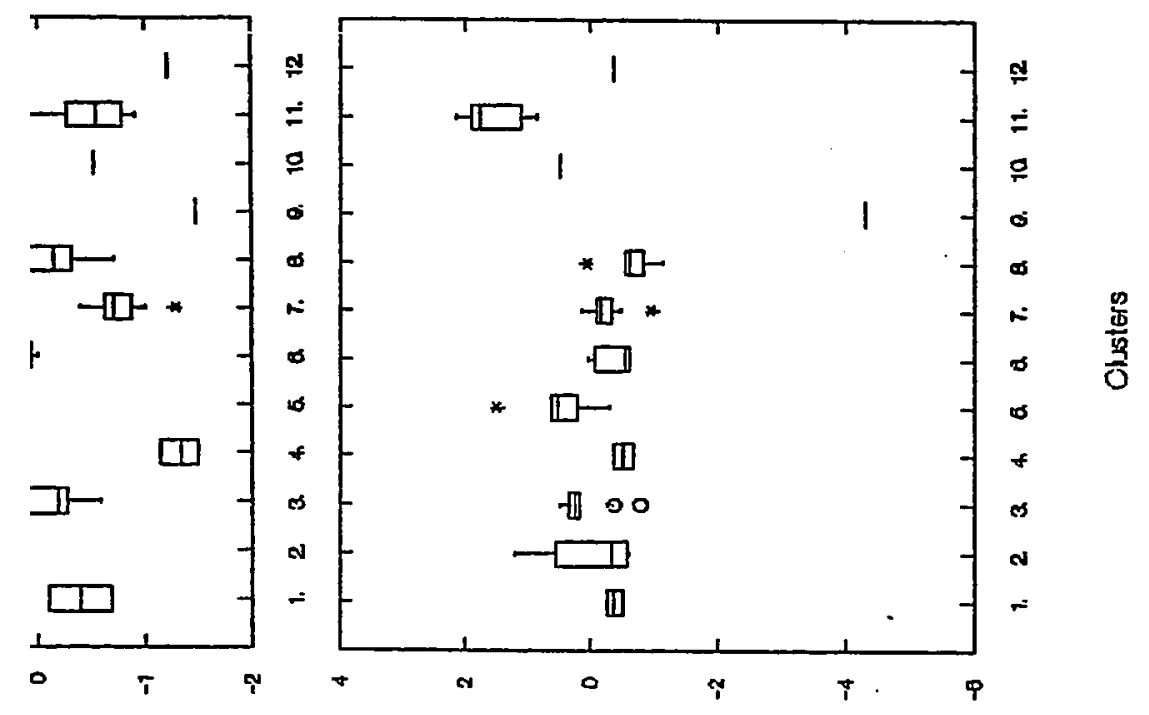

[E]O1

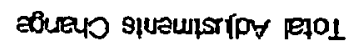

$\frac{\sqrt{5}}{\frac{2}{2}}$

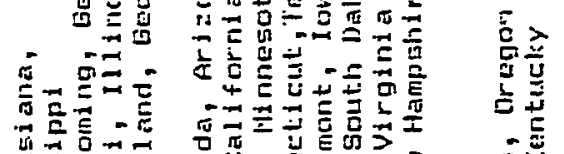

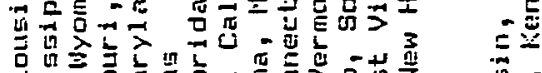

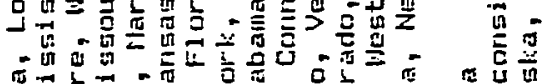

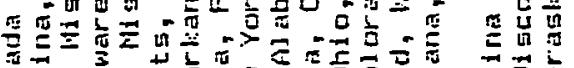

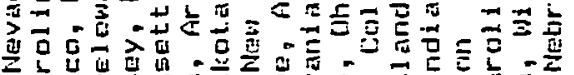

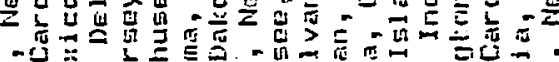

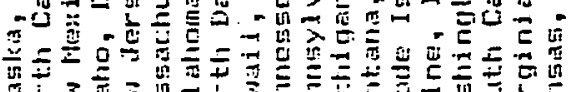

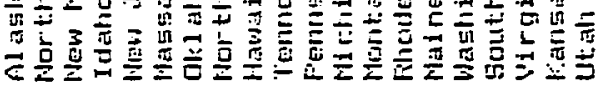

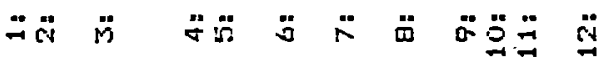

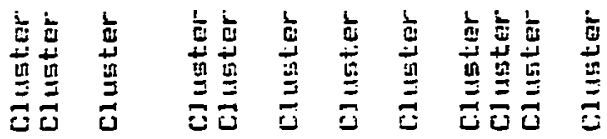
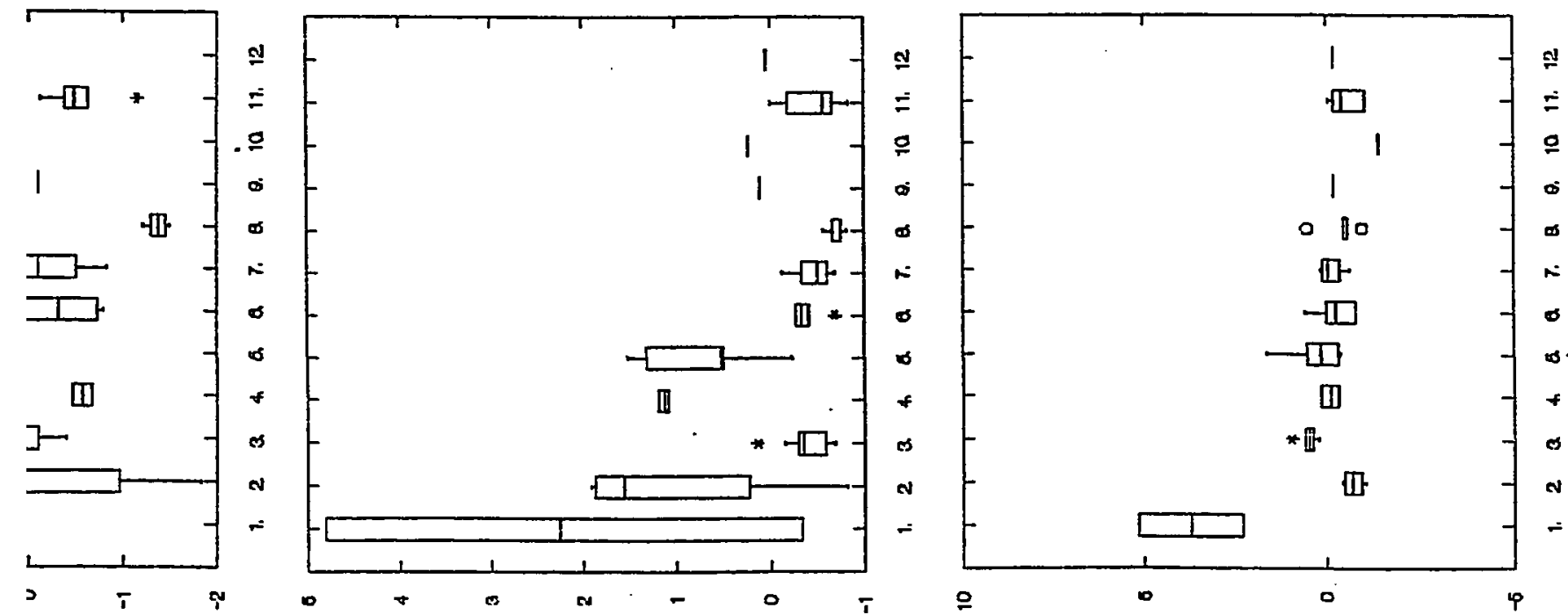

$\checkmark \times E_{\perp}$

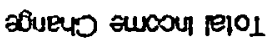

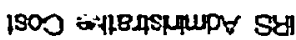


APPENDIX D

TEMP HANDBOOK 
.

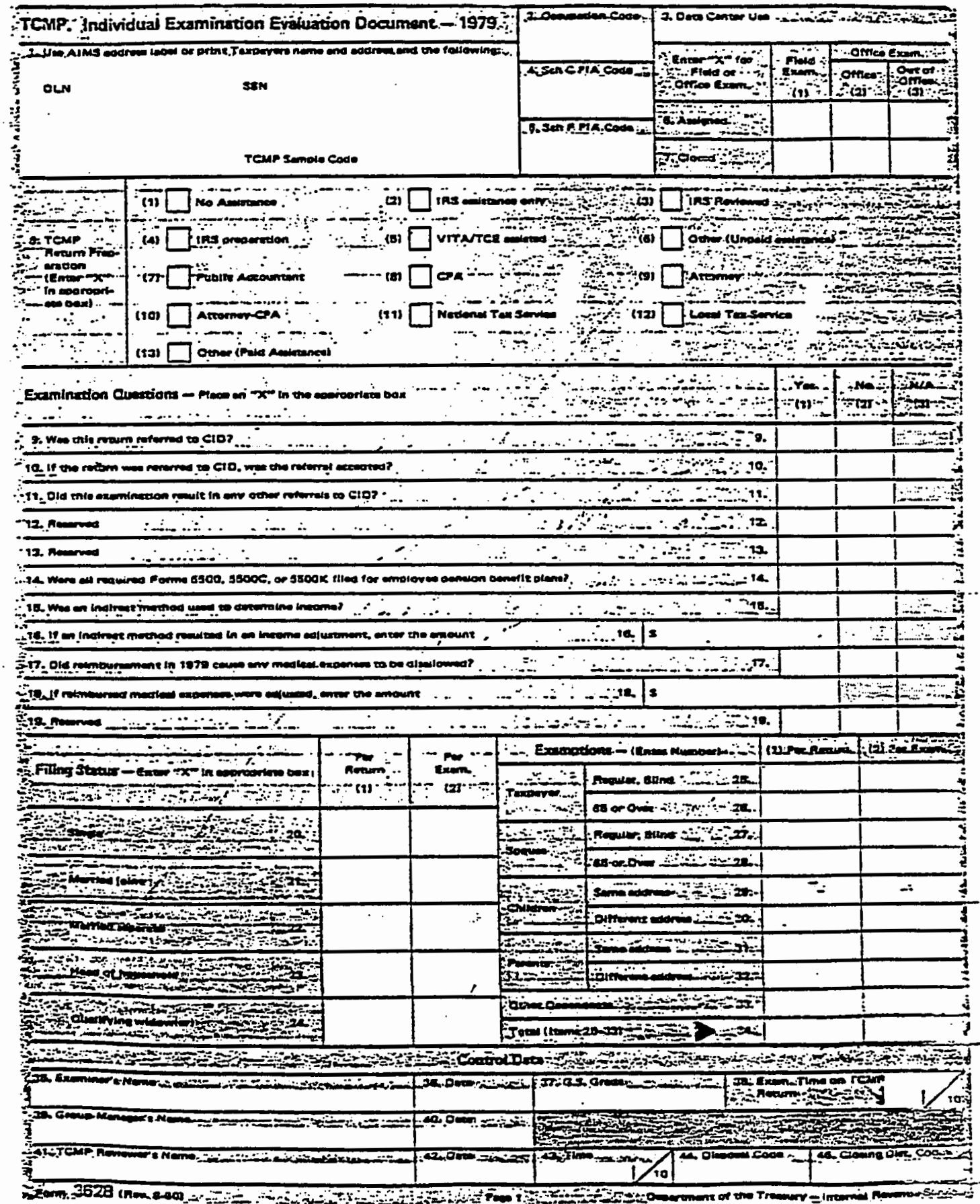




\begin{tabular}{|c|c|c|c|}
\hline \multirow{2}{*}{ 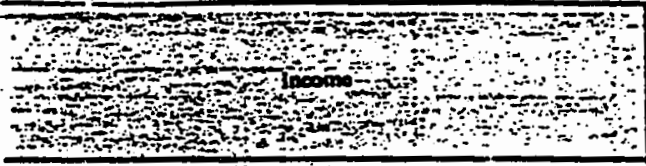 } & \multicolumn{2}{|c|}{ 4in on } & 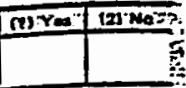 \\
\hline & 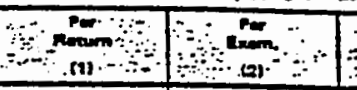 & 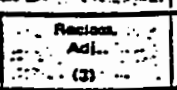 & 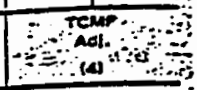 \\
\hline \multicolumn{4}{|c|}{ 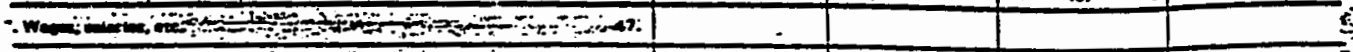 } \\
\hline 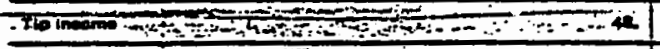 & ' & & $\underline{-1}$ \\
\hline \multicolumn{4}{|l|}{ 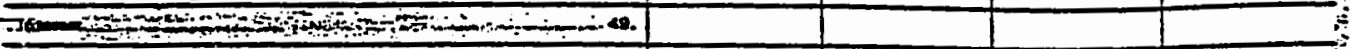 } \\
\hline \multicolumn{4}{|l|}{ 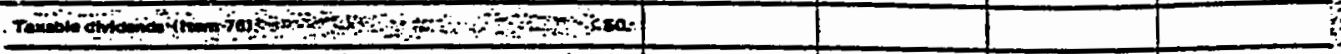 } \\
\hline \multicolumn{4}{|l|}{ 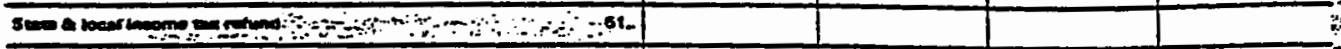 } \\
\hline \multicolumn{4}{|l|}{ Almonots } \\
\hline \multicolumn{4}{|l|}{ 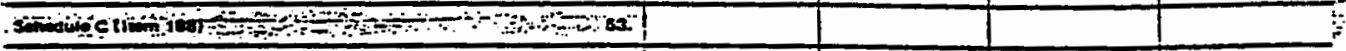 } \\
\hline \multicolumn{4}{|l|}{ 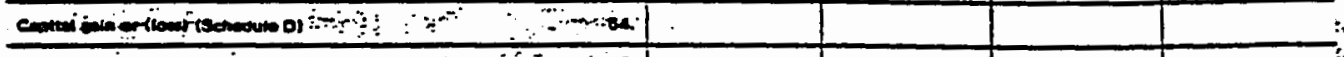 } \\
\hline \multicolumn{4}{|l|}{ 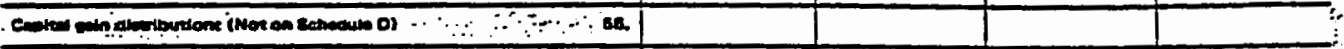 } \\
\hline \multicolumn{4}{|l|}{ 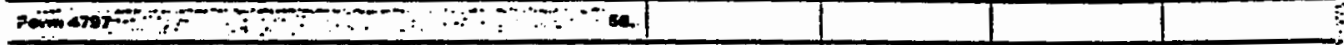 } \\
\hline \multicolumn{4}{|l|}{ 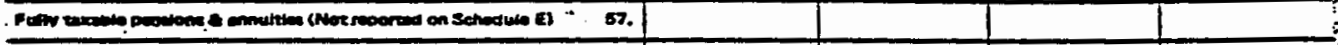 } \\
\hline \multicolumn{4}{|l|}{ 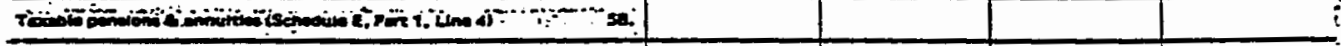 } \\
\hline \multicolumn{4}{|l|}{ 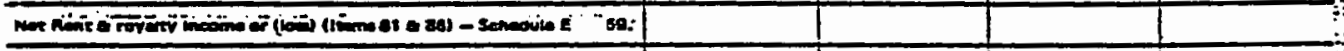 } \\
\hline \multicolumn{4}{|l|}{ 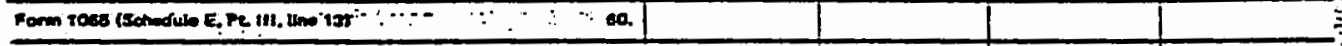 } \\
\hline \multicolumn{4}{|l|}{ 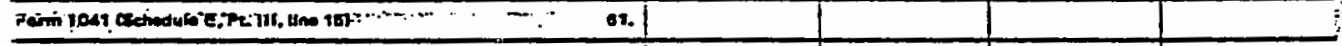 } \\
\hline \multicolumn{4}{|l|}{ 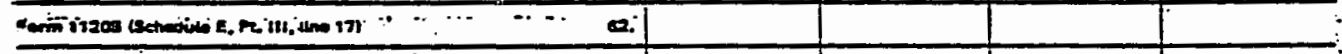 } \\
\hline \multicolumn{4}{|l|}{ 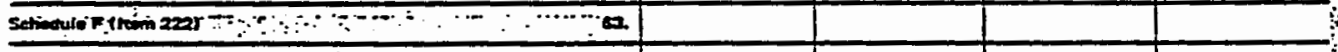 } \\
\hline \multicolumn{4}{|l|}{ 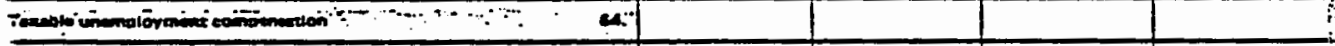 } \\
\hline \multicolumn{4}{|l|}{ 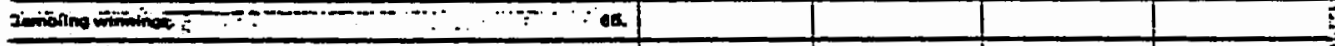 } \\
\hline \multicolumn{4}{|l|}{ 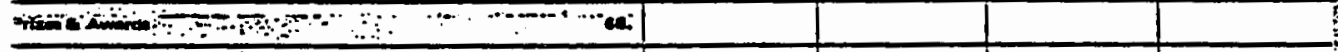 } \\
\hline \multicolumn{4}{|l|}{ 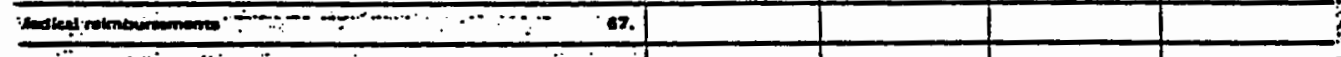 } \\
\hline \multirow{2}{*}{\multicolumn{4}{|c|}{ 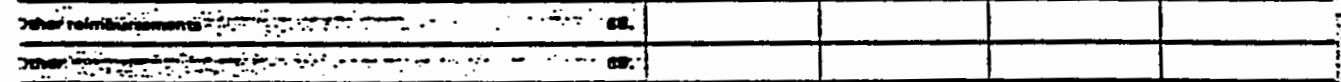 }} \\
\hline & & & \\
\hline \multicolumn{4}{|c|}{ 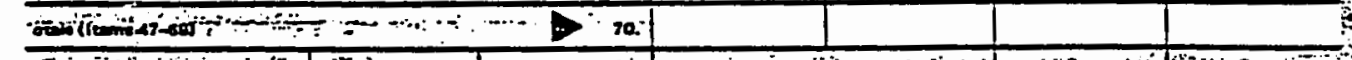 } \\
\hline 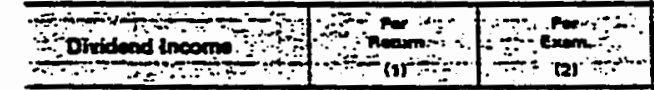 & Rem incomand & 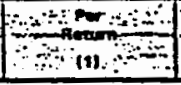 & 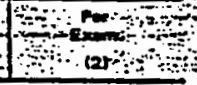 \\
\hline \multirow{2}{*}{ mannoomian: } & 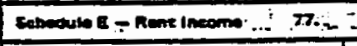 & $\square$ Nerenoptices & ancon \\
\hline & 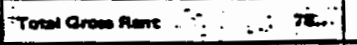 & & \\
\hline 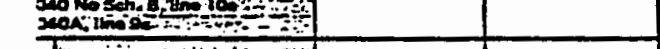 & 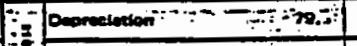 & & \\
\hline Fop & 200000 & & \\
\hline 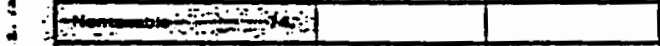 & 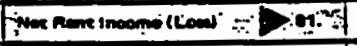 & & \\
\hline fond & 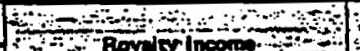 & ond & 00 \\
\hline 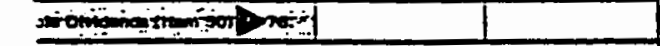 & 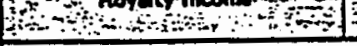 & $8+(1)+2$ & \\
\hline (1) & 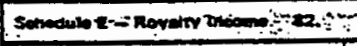 & 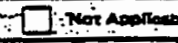 & \\
\hline & 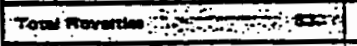 & & \\
\hline & 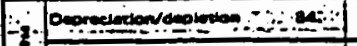 & & \\
\hline - & 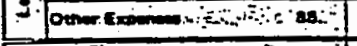 & & \\
\hline & 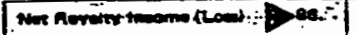 & & \\
\hline
\end{tabular}

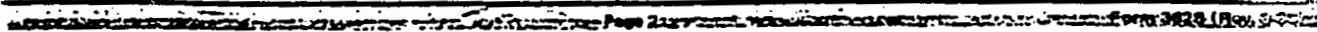




\begin{tabular}{|c|c|c|c|c|}
\hline 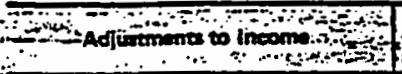 & nim & \multirow{2}{*}{ 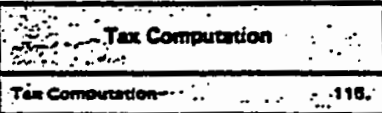 } & rer nowam: & Aram \\
\hline 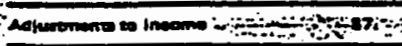 & 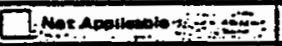 & & Q Wot Aoolh & $+\infty+\infty .-\because \because$ \\
\hline mone ow & & 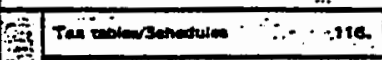 & & \\
\hline 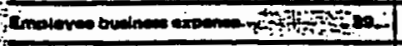 & & sencivina & & \\
\hline 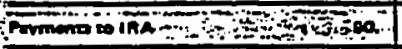 & & Form ario (nienumums - - ive & & \\
\hline 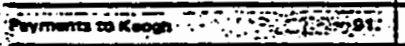 & & 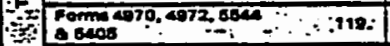 & & \\
\hline 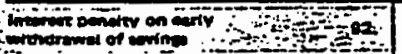 & & $\operatorname{sen} r z(m)(8)$ nonder $: \because 20$ & & \\
\hline 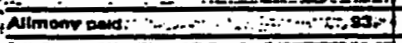 & & 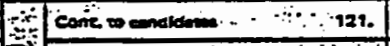 & & \\
\hline 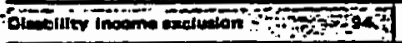 & & 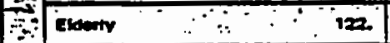 & & \\
\hline 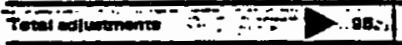 & & 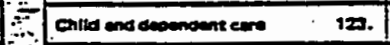 & & \\
\hline 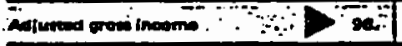 & & Imeoment & & \\
\hline 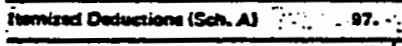 & 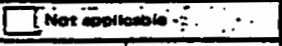 & 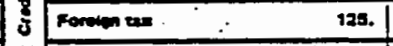 & & \\
\hline 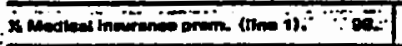 & & Wort incenstur (WIIN) & & \\
\hline 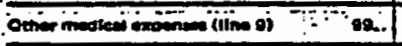 & & $\therefore \operatorname{son}$ & & \\
\hline 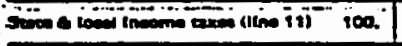 & & 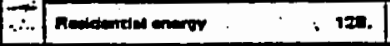 & & \\
\hline 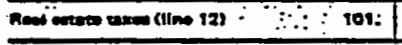 & & \multirow{2}{*}{$\therefore=128$} & & \\
\hline 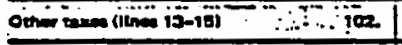 & & & & \\
\hline 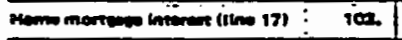 & & \multirow{2}{*}{ 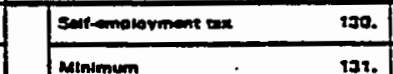 } & & \\
\hline 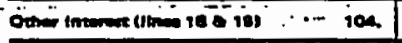 & & & & \\
\hline 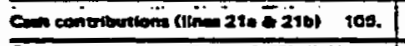 & & 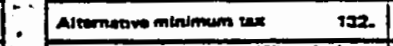 & & \\
\hline 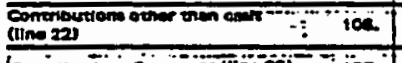 & & 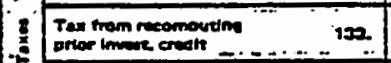 & & \\
\hline 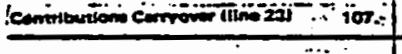 & & 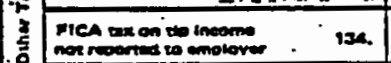 & & \\
\hline 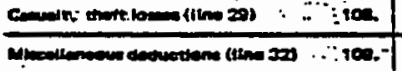 & - & 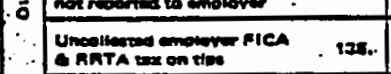 & & \\
\hline 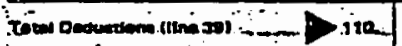 & & $\therefore \operatorname{Tax}$ on m inA & & \\
\hline Zeros sromere anount & & 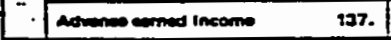 & & \\
\hline 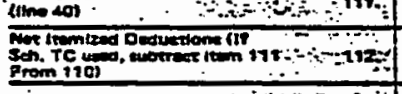 & & 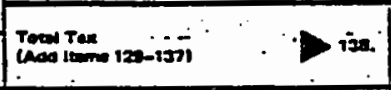 & & \\
\hline 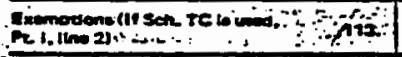 & & $\therefore$ Inecom Tax withonad & & \\
\hline 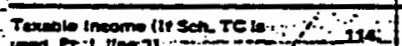 & & 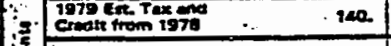 & & \\
\hline 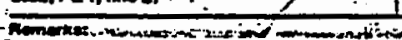 & & 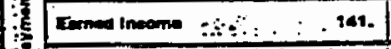 & & \\
\hline & & 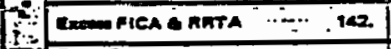 & & \\
\hline & & 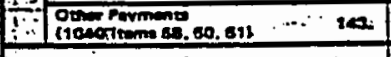 & & \\
\hline & & Tow iniments & & \\
\hline & & ampoos & & \\
\hline 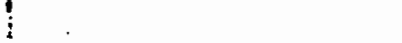 & & somenes owe & & \\
\hline - & & minertion & & \\
\hline$\vdots$ & & \multicolumn{3}{|c|}{ 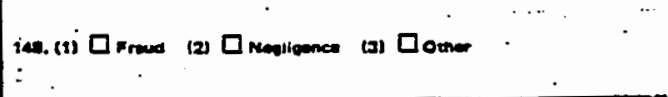 } \\
\hline
\end{tabular}




\begin{tabular}{|c|c|c|c|c|}
\hline \multicolumn{2}{|c|}{ 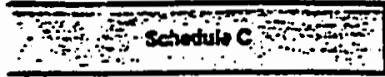 } & 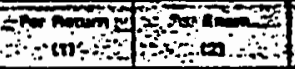 & 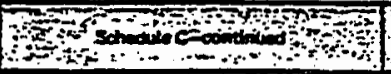 & 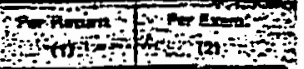 \\
\hline \multicolumn{2}{|c|}{ 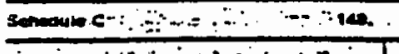 } & 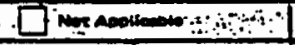 & 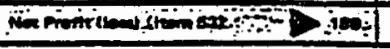 & \begin{tabular}{l|l} 
& \\
\end{tabular} \\
\hline \multicolumn{2}{|c|}{ 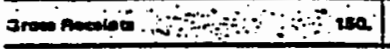 } & & \multicolumn{2}{|c|}{ 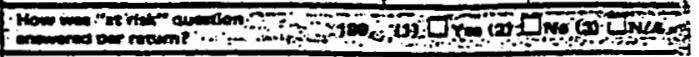 } \\
\hline \multicolumn{2}{|c|}{ 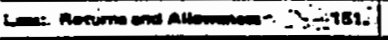 } & & \multicolumn{2}{|c|}{ 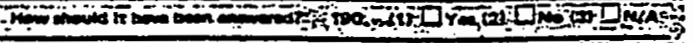 } \\
\hline \multicolumn{2}{|c|}{ 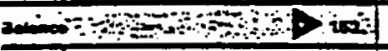 } & & \multicolumn{2}{|c|}{ 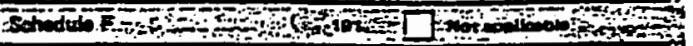 } \\
\hline \multirow{3}{*}{ 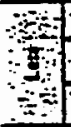 } & 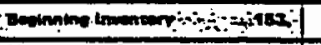 & & \multicolumn{2}{|c|}{ 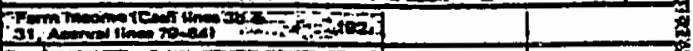 } \\
\hline & 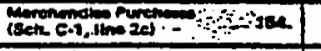 & & encon & 勧 \\
\hline & 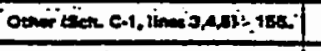 & & $=7$ and & 然 \\
\hline \multicolumn{2}{|c|}{ 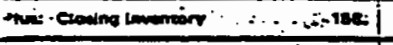 } & & 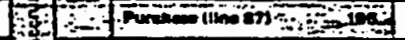 & 酸 \\
\hline \multicolumn{2}{|c|}{ 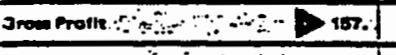 } & & 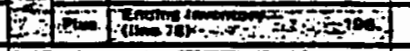 & 悲 \\
\hline \multicolumn{2}{|c|}{ 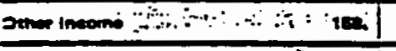 } & & 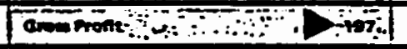 & 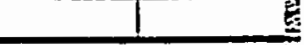 \\
\hline \multicolumn{2}{|c|}{ Toven income $\quad \cdots:$} & & 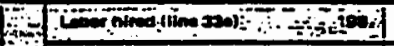 & 焉 \\
\hline \multirow[b]{3}{*}{$\therefore$} & Nomeritno. & & 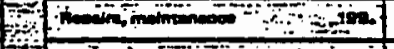 & 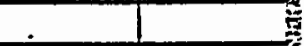 \\
\hline & Amerisention & & $=\operatorname{mon}-\quad ; \quad \because 2000$ & 8 \\
\hline & 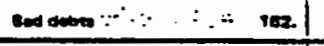 & & 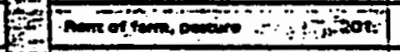 & tiv \\
\hline \multirow{2}{*}{$\because$} & 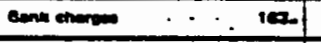 & & 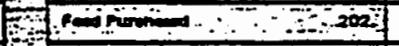 & 焉 \\
\hline & 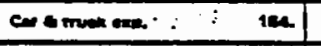 & & 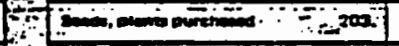 & $x$ \\
\hline & Canminanom. & & 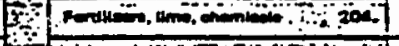 & 幽 \\
\hline & Deolanion & & 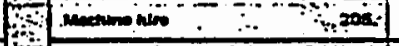 & 象 \\
\hline & Domencimion & & 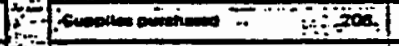 & (1) \\
\hline$\because \because$ & 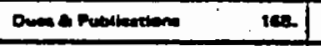 & & 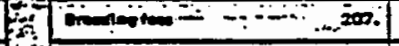 & 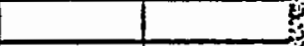 \\
\hline & 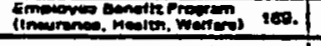 & & 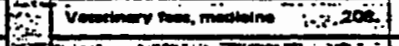 & 8 \\
\hline & 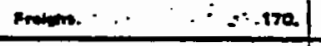 & & 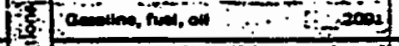 & 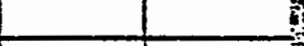 \\
\hline & Imaminese & & 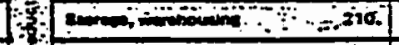 & is \\
\hline 疍 & Inomere $\cdots$ & & Tis $:$ : & s. \\
\hline & 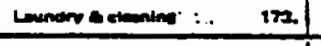 & & timinon: 212 & 3 \\
\hline & 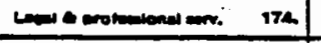 & & $\therefore$ uencin $\because: \cdots$, & 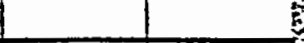 \\
\hline$\therefore$ & crinen anooilen $\quad \because 175$. & & 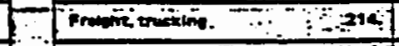 & -5 \\
\hline$\therefore$ & 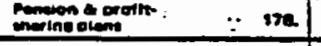 & & 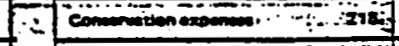 & 8 \\
\hline & norem : . & & 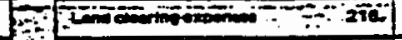 & 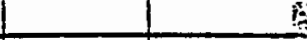 \\
\hline 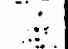 & $.17 \pi \cdot$ & & 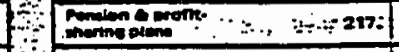 & 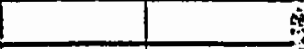 \\
\hline & $\because: \quad \cdots, \ldots$ & & 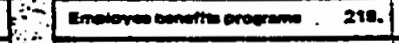 & 5 \\
\hline$\because \because$ & 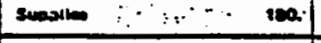 & & 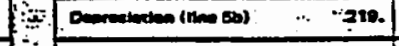 & \\
\hline & Tem: : & & oon $\because \because \cdots \cdots \cdots$ & \\
\hline & Tonomone : : : : & & 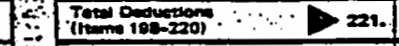 & \\
\hline$\because \vdots$ & 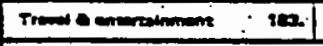 & & 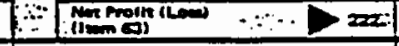 & 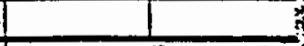 \\
\hline & 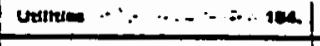 & & 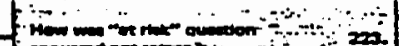 & (1) \\
\hline 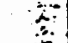 & 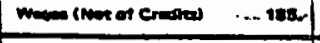 & & 8. & \\
\hline$\because$ & Otrem expons. & & 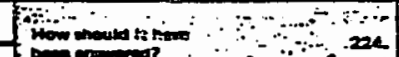 & 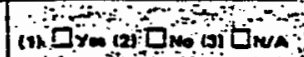 \\
\hline & 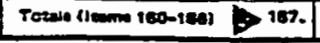 & & $\because$ & 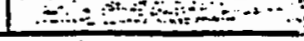 \\
\hline
\end{tabular}




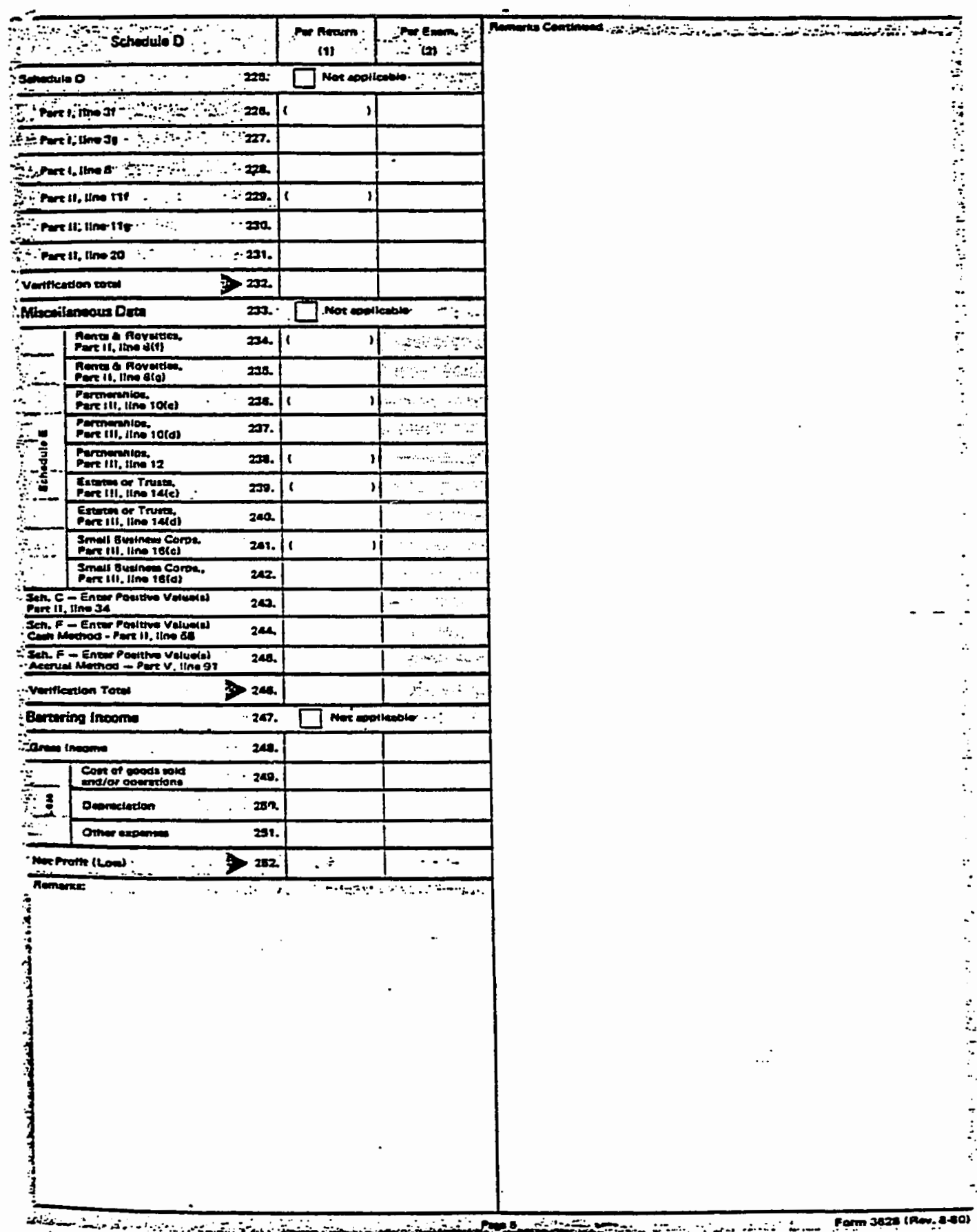

